Nevada

Environmental

Restoration

Project

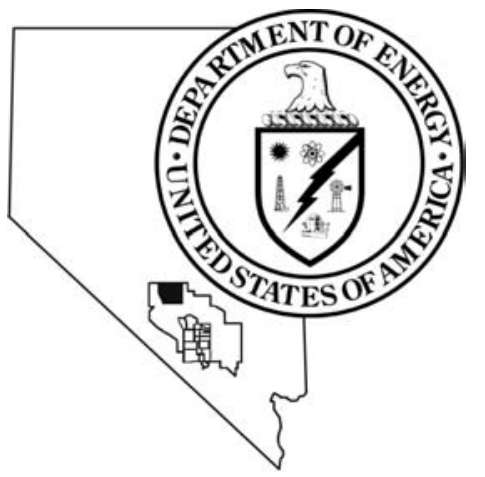

Corrective Action Decision Document for Corrective Action Unit 490:

Station 44 Burn Area

Tonopah Test Range, Nevada

Controlled Copy No.:

Revision No.: 0

February 2001

Approved for public release; further dissemination unlimited.

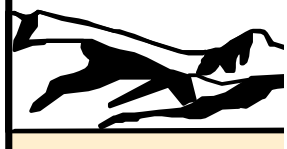

Environmental Restoration

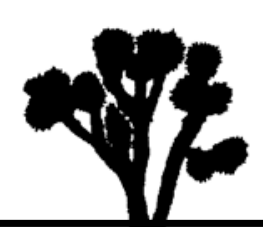

Division 
Available for public sale, in paper, from:

\author{
U.S. Department of Commerce \\ National Technology Information Service \\ 5285 Port Royal Road \\ Springfield, VA 22161 \\ Phone: 800.553 .6847 \\ Fax: 703.605.6900 \\ Email: orders@ntis.fedworld.gov \\ Online ordering: http//www.ntis.gov/ordering.htm
}

Available electronically at http://www.doe.gov/bridge.

Available for a processing fee to U.S. Department of Energy and its contractors, in paper, from:

\author{
U.S. Department of Energy \\ Office of Scientific and Technical Information \\ P.O. Box 62 \\ Oak Ridge, TN 37831-0062 \\ Phone: 865.576 .8401 \\ Fax: 865.576.5728 \\ Email: reports@adonis.osti.gov
}

Reference herein to any specific commercial product, process, or service by trade name, trademark, manufacturer, or otherwise, does not necessarily constitute or imply its endorsement, recommendation, or favoring by the United States Government or any agency thereof or its contractors or subcontractors. 


\section{CORRECTIVE ACTION DECISION DOCUMENT FOR CORRECTIVE ACTION UNIT 490: STATION 44 BURN AREA TONOPAH TEST RANGE, NEVADA}

DOE Nevada Operations Office

Las Vegas, Nevada

Controlled Copy No.:

Revision No.: 0

February 2001

Approved for public release; further dissemination unlimited. 


\section{CORRECTIVE ACTION DECISION DOCUMENT \\ FOR CORRECTIVE ACTION UNIT 490: \\ STATION 44 BURN AREA \\ TONOPAH TEST RANGE, NEVADA}

Approved by:

Janet Appenzeller-Wing, Project Manager

Industrial Sites Project

Approved by:

Date: 2/23/01

Runore C. Wycoff, Division Director

Environmental Restoration Division 


\section{Table of Contents}

List of Figures $\ldots \ldots \ldots \ldots \ldots \ldots \ldots \ldots \ldots \ldots \ldots \ldots \ldots \ldots \ldots \ldots \ldots \ldots \ldots \ldots$

List of Tables. . . . . . . . . . . . . . . . . . . . . . . . . .

List of Acronyms and Abbreviations $\ldots \ldots \ldots \ldots \ldots \ldots \ldots \ldots \ldots \ldots \ldots \ldots \ldots \ldots \ldots$

Executive Summary . . . . . . . . . . . . . . . . . . . . . . . . . . ES-1

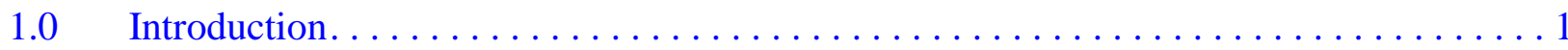

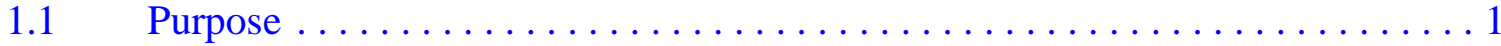

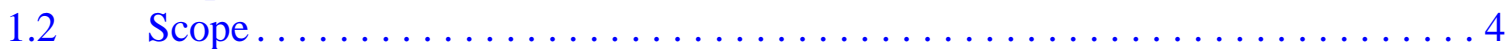

$1.3 \quad$ CADD Contents $\ldots \ldots \ldots \ldots \ldots \ldots \ldots \ldots \ldots \ldots \ldots \ldots \ldots \ldots$

$2.0 \quad$ Corrective Action Investigation Summary $\ldots \ldots \ldots \ldots \ldots \ldots \ldots \ldots \ldots \ldots \ldots \ldots \ldots \ldots$

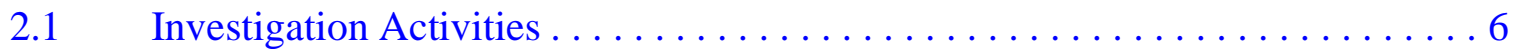

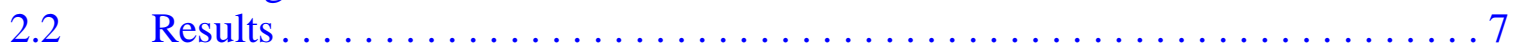

$2.3 \quad$ Need for Corrective Action . . . . . . . . . . . . . . . . . . 10

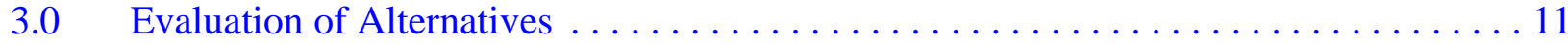

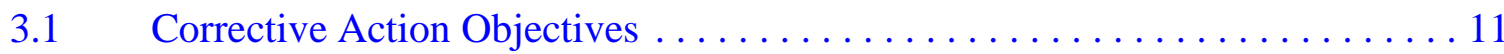

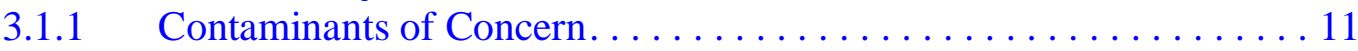

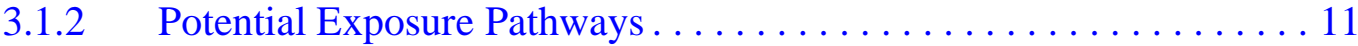

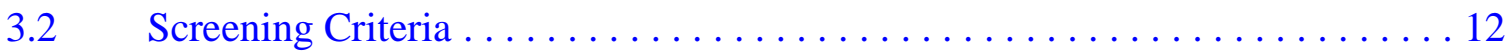

3.2.1 Corrective Action Standards . . . . . . . . . . . . . . . . . 12

3.2.2 Remedy Selection Decision Factors. . . . . . . . . . . . . . . . . 14

3.3 Development of Corrective Action Alternatives. . . . . . . . . . . . . . 16

3.3.1 Alternative 1 - No Further Action . . . . . . . . . . . . . 18

3.3.2 Alternative 2 - Closure in Place with Administrative Controls . . . . . . 18

3.3.3 Alternative 3 - Clean Closure by Excavation and Disposal . . . . . . . 18

3.3.3.1 CAU 424 Use Restriction Area . . . . . . . . . . . . . . 19

3.4 Evaluation and Comparison of Alternatives . . . . . . . . . . . . . 19

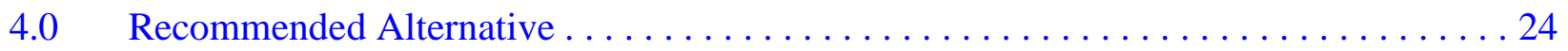

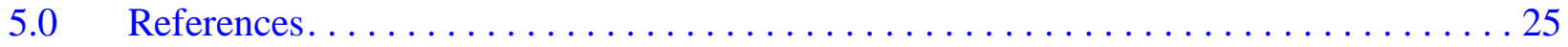

\section{Appendix A - Corrective Action Investigation Report for CAU 490: Station 44 Burn Area Tonopah Test Range, Nevada}

A.1.0 Introduction. . . . . . . . . . .

A.1.1 Project Objectives . . . . . . . . . . . . . . . .

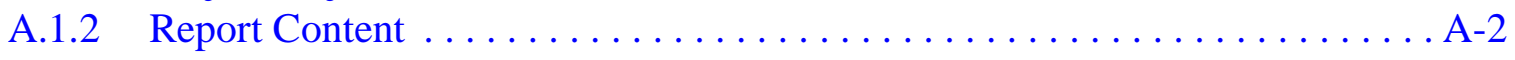




\section{Table of Contents (Continued)}

A.2.0 Field Investigation and Sampling Activities. . . . . . . . . . . . A-3

A.2.1 Site Description and Conditions . . . . . . . . . . . . . . A-4

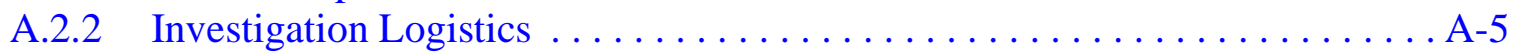

A.2.2.1 Utility Clearances. . . . . . . . . . . . . . . . . . . A-5

A.2.2.2 Excavation Sampling ...................... A-5

A.2.2.3 Direct-Push. . . . . . . . . . . . . . . . . . . . . . . A-6

A.2.3 Fire Training Area, CAS 03-56-001-03BA Investigation. . . . . . . . . . . A-6

A.2.4 Station 44 Burn Area, CAS RG-56-001-RGBA Investigation . . . . . . . . . . . A-7

A.2.5 Sandia Service Yard, CAS 03-58-001-03FN Investigation . . . . . . . . . . . A-9

A.2.6 Gun Propellant Burn Area, CAS 09-54-001-09L2 Investigation . . . . . . . . A-13

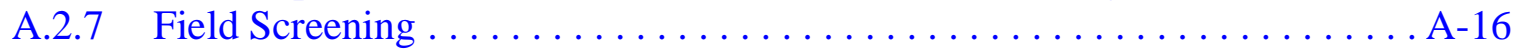

A.2.8 Sample Collection . . . . . . . . . . . . . . . . . . . . . A-17

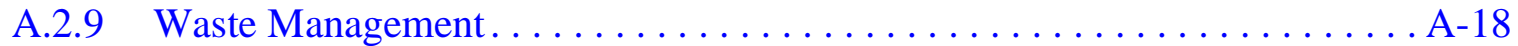

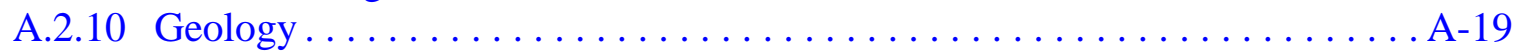

A.2.11 Hydrology . . . . . . . . . . . . . . . . . . . . 19

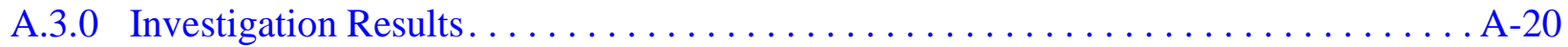

A.3.1 Total Volatile Organic Compounds ..................... A-20

A.3.2 Total Semivolatile Organic Compounds. . . . . . . . . . . . . . . . . A-29

A.3.3 Total Petroleum Hydrocarbons . . . . . . . . . . . . . . . . . . . A-29

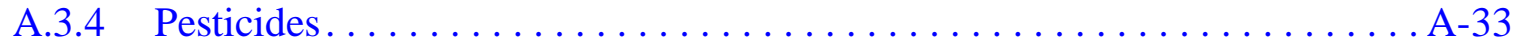

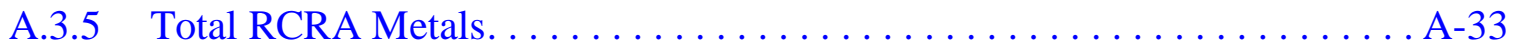

A.3.6 Total PCB Results . . . . . . . . . . . . . . . . . . . . . A-39

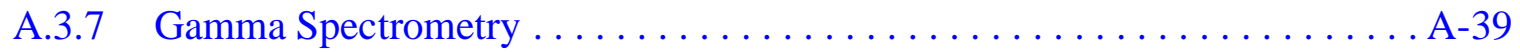

A.3.8 Isotopic Uranium Results . . . . . . . . . . . . . . . . . A-39

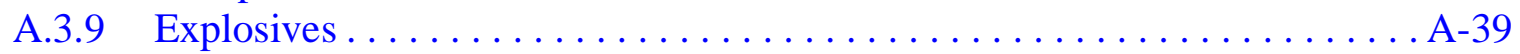

A.3.10 Rocket Resin Results from GPBA . . . . . . . . . . . . . . A-46

A.4.0 Quality Assurance. . . . . . . . . . . . . . . . . . . . . . . . A-48

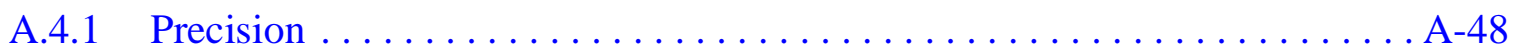

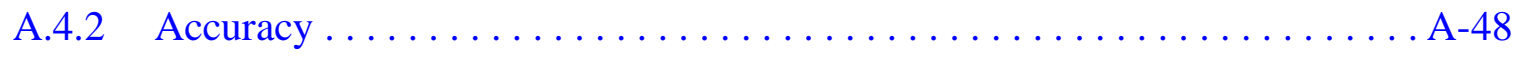

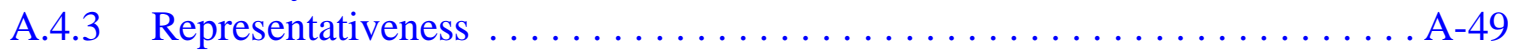

A.4.4 Completeness ............................. A-49

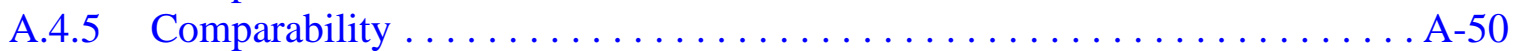

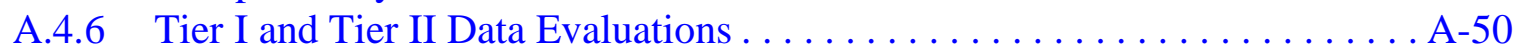

A.4.6.1 Tier I Evaluation. . . . . . . . . . . . . . . . . . . . . A-51

A.4.6.2 Tier II Evaluation . . . . . . . . . . . . . . . A $\ldots \ldots 1$

A.4.6.3 Tier III Evaluation . . . . . . . . . . . . . . . . A-53

A.4.7 Quality Control Samples . . . . . . . . . . . . . . . . . . . . A-53

A.4.7.1 Field Quality Control Samples. . . . . . . . . . . . . . . A-54 


\section{Table of Contents (Continued)}

A.4.7.2 Laboratory Quality Control Samples . . . . . . . . . . . . . . . . A-55

A.4.8 Field Nonconformances . . . . . . . . . . . . . . . . . . . . . . . . . A-57

A.4.9 Laboratory Nonconformances. . . . . . . . . . . . . . . . . . A-58

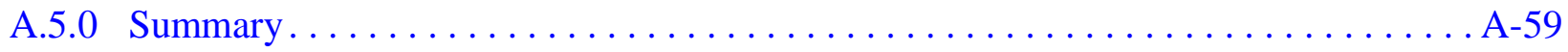

A.6.0 References...................................

Appendix B - Cost Estimates for CAU 490

Appendix C - Evaluation of Risk

Appendix D - Response to NDEP Comments 


\section{List of Figures}

Number

1-1 Tonopah Test Range Location Map. . . . . . . . . . . . . . . . 2

1-2 Approximate Locations of CAU 490 CASs, Tonopah Test Range . . . . . . . . . . 3

A.2-1 Fire Training Area Sampling Locations, Tonopah Test Range . . . . . . . . . . A-8

A.2-2 Station 44 Burn Area Sampling Locations, Tonopah Test Range . . . . . . . . . . A A-10

A.2-3 Sandia Service Yard Sampling Locations, Tonopah Test Range . . . . . . . . . . A-12

A.2-4 Gun Propellant Burn Area Showing Sampling Locations, Tonopah Test Range . . A-14

A.2-5 Gun Propellant Burn Area Showing Location of Background Radiological

Soils Samples, Tonopah Test Range . . . . . . . . . . . . . . . . A-15 


\section{List of Tables}

Number

3-1 Detailed Evaluation of Alternatives. . . . . . . . . . . . . . . . . . . . . . 20

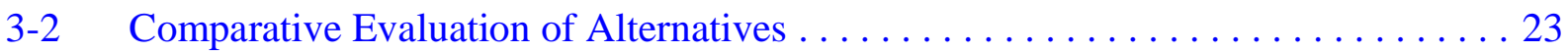

A.3-1 CAU 490, Station 44 Burn Area, Tonopah Test Range Sampling Locations and Analyses...................... A-21

A.3-2 Laboratory Analytical Methods Used for Samples Collected at CAU 490, Station 44 Burn Area, Tonopah Test Range. . . . . . . . . . . . . . . A-28

A.3-3 Soil Sample Results for Total Volatile Organic Compounds Detected Above Minimum Reporting Limits, CAU 490, Station 44 Burn Area ..

A.3-4 Soil Sample Results for Total Petroleum Hydrocarbons at CAU 490,

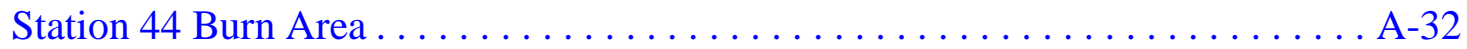

A.3-5 Soil Sample Results for Total RCRA Metals Detected Above Minimum Reporting Limits, CAU 490, Station 44 Burn Area ................. A-34

A.3-6 Soil Sample Results for Gamma-Emitting Radionuclides Above MRLs, CAU 490, Station 44 Burn Area . . . . . . . . . . . . . . . . . . A-40

A.3-7 Soil Sample Results for Isotopic Uranium and Isotopic Plutonium, CAU 490, Station 44 Burn Area . . . . . . . . . . . . . . . . . . . . . . . A-43

A.3-8 Soil Sample Results for Nitrocellulose, CAU 490, Station 44 Burn Area . . . . . . A-45

A.3-9 Summary of Rocket Resin Analytical Results From GPBA Detected Above Minimum Detectable Concentrations, CAU 490, Station 44 Burn Area. . . . . . . . A-47 


\section{List of Acronyms and Abbreviations}

\begin{tabular}{|c|c|}
\hline bgs & Below ground surface \\
\hline CADD & Corrective Action Decision Document \\
\hline CAIP & Corrective Action Investigation Plan \\
\hline CAS & Corrective Action Site \\
\hline CAU & Corrective Action Unit \\
\hline CFR & Code of Federal Regulations \\
\hline CLP & Contract Laboratory Program \\
\hline $\mathrm{cm}$ & Centimeter(s) \\
\hline $\mathrm{COC}$ & Contaminant(s) of concern \\
\hline COPC & Contaminant(s) of potential concern \\
\hline DOE & U.S. Department of Energy \\
\hline dpm & Disintegration(s) per minute \\
\hline DQO & Data Quality Objectives \\
\hline EPA & U.S. Environmental Protection Agency \\
\hline FADL & Field Activity Daily Log \\
\hline FFACO & Federal Facility Agreement and Consent Order \\
\hline FSL & Field-screening level(s) \\
\hline $\mathrm{ft}$ & Foot (feet) \\
\hline $\mathrm{ft}^{2}$ & Square foot (feet) \\
\hline FTA & Fire Training Area \\
\hline GPBA & Gun Propellant Burn Area \\
\hline HWAA & Hazardous Waste Accumulation Area \\
\hline $\mathrm{ICB}$ & Initial calibration blank \\
\hline ICP & Inductively coupled plasma \\
\hline IDW & Investigation-derived waste \\
\hline in. & Inch(es) \\
\hline
\end{tabular}




\section{List of Acronyms and Abbreviations (Continued)}

\begin{tabular}{|c|c|}
\hline JATO & Jet Assisted Take Off \\
\hline LCS & Laboratory control samples \\
\hline $\mathrm{mg} / \mathrm{kg}$ & Milligram(s) per kilogram \\
\hline $\mathrm{mg} / \mathrm{L}$ & Milligram(s) per liter \\
\hline $\mathrm{mi}$ & Mile(s) \\
\hline MS/MSD & Matrix spike/matrix spike duplicate \\
\hline NAC & Nevada Administrative Code \\
\hline NDEP & Nevada Division of Environmental Protection \\
\hline NIST & National Institute for Standards and Technology \\
\hline NRS & Nevada Revised Statutes \\
\hline NTS & Nevada Test Site \\
\hline PAL & Preliminary action level(s) \\
\hline PCB & Polychlorinated biphenyl(s) \\
\hline $\mathrm{pCi} / \mathrm{g}$ & Picocurie(s) per gram \\
\hline PID & Photoionization detector \\
\hline PPE & Personal protective equipment \\
\hline ppm & Part(s) per million \\
\hline PRG & Preliminary remediation goal(s) \\
\hline PVC & Polyvinyl chloride \\
\hline QA & Quality assurance \\
\hline QAPP & Quality Assurance Project Plan \\
\hline QC & Quality control \\
\hline RCRA & Resource Conservation and Recovery Act \\
\hline RDX & Royal Demolition Explosive (Cyclotrimethylene Trinitramine) \\
\hline RPD & Relative percent difference \\
\hline SAA & Satellite Accumulation Area \\
\hline
\end{tabular}




\section{List of Acronyms and Abbreviations (Continued)}

SDG

Sample delivery group

SSY

Sandia Service Yard

STA44

Station 44 Burn Area

SVOC

Semivolatile organic compound(s)

TCLP

Toxicity Characteristic Leaching Procedure

$\mathrm{TPH}$

Total petroleum hydrocarbon(s)

TTR

Tonopah Test Range

$\mu \mathrm{g} / \mathrm{kg}$

Microgram(s) per kilogram

$\mu \mathrm{g} / \mathrm{L}$

Microgram(s) per liter

VOC

Volatile organic compound(s)

WEC

Westinghouse Electric Company

$\% \mathrm{R}$

Percent recovery 


\section{Executive Summary}

This Corrective Action Decision Document has been prepared for Corrective Action Unit 490: Station 44 Burn Area, Tonopah Test Range, Nevada, in accordance with the Federal Facility Agreement and Consent Order (1996). This Corrective Action Unit is located near Areas 3 and 9 within the Tonopah Test Range, Nevada. Corrective Action Unit 490 is comprised of the following Corrective Action Sites (CAS):

- $\quad$ Fire Training Area (CAS 03-56-001-03BA)

- Station 44 Burn Area (CAS RG-56-001-RGBA)

- Sandia Service Yard (CAS 03-58-001-03FN)

- Gun Propellant Burn Area (CAS 09-54-001-09L2)

The purpose of this Corrective Action Decision Document is to identify and provide a rationale for the selection of a recommended corrective action alternative for each Corrective Action Site.

The scope of this Corrective Action Decision Document consists of the following tasks:

- Develop corrective action objectives.

- Identify corrective action alternative screening criteria.

- Develop corrective action alternatives.

- Perform detailed and comparative evaluations of the corrective action alternatives in relation to the corrective action objectives and screening criteria.

- Recommend and justify a preferred corrective action alternative for each Corrective Action Site.

In July and August 2000, a corrective action investigation was performed as set forth in the Corrective Action Investigation Plan (DOE/NV, 2000). Analytes detected during the corrective action investigation were evaluated against preliminary action levels to determine contaminants of concern for each Corrective Action Site. There were no contaminants of concern identified in soil at the Gun Propellant Burn Area, or Station 44 Burn Area, so there is no need for corrective actions at these sites. At Corrective Action Site 03-56-001-03BA, Fire Training Area, five soil samples exceeded preliminary action levels for total petroleum hydrocarbons-diesel; and seven soil samples 
exceeded preliminary action levels for total petroleum hydrocarbons-diesel at the Sandia Service Yard (CAS 03-58-001-03FN).

Based on the identification of contaminants of concern above preliminary action levels at this Corrective Action Unit, potential corrective action alternatives are identified and evaluated in this Corrective Action Decision Document to ensure worker, public, and environmental protection against potential exposure to contaminants of concern in accordance with Nevada Administrative Code 445A (NAC, 1998b).

Based on the potential exposure pathways, the following corrective action objectives have been identified for the Fire Training Area and Sandia Service Yard at Corrective Action Unit 490:

- Prevent or mitigate exposure to surface and near-surface soil containing contaminants of concern at concentrations exceeding preliminary action levels as defined in the Corrective Action Investigation Plan (DOE/NV, 2000).

- Prevent spread of contaminants of concern beyond the Corrective Action Site.

Based on the review of existing data, future use, and current operations at the Tonopah Test Range, the following alternatives have been developed for consideration at Corrective Action Unit 490:

- Alternative 1 - No Further Action

- Alternative 2 - Closure In Place - No Further Action With Administrative Controls

- Alternative 3 - Clean Closure by Excavation and Disposal

The corrective action alternatives were evaluated based on four general corrective action standards and five remedy selection decision factors. Based on the results of this evaluation, the preferred alternative for Corrective Action Unit 490 is Alternative 3, Clean Closure by Excavation and Disposal.

The preferred corrective action alternative was evaluated on technical merit, focusing on performance, reliability, feasibility, and safety. The alternative was judged to meet all requirements for the technical components evaluated. The alternative meets all applicable state and federal regulations for closure of the site and will eliminate potential future exposure pathways to the contaminated soils at Corrective Action Unit 490. 
During corrective action implementation, this alternative may present a potential threat to site workers who perform the remedial action and who come in contact with the contaminated soil. However, procedures will be developed and implemented to ensure worker health and safety. 


\subsection{Introduction}

This Corrective Action Decision Document (CADD) has been prepared for Corrective Action Unit (CAU) 490: Station 44 Burn Area at the Tonopah Test Range (TTR), Nevada, in accordance with the Federal Facility Agreement and Consent Order (FFACO) that was agreed to by the State of Nevada, the U.S. Department of Energy (DOE), and the U.S Department of Defense (FFACO, 1996). The CADD provides or references the specific information necessary to recommend corrective actions for the Corrective Action Sites (CASs) within CAU 490.

Corrective Action Unit 490 is comprised of the following CASs:

- Fire Training Area (CAS 03-56-001-03BA)

- Station 44 Burn Area (CAS RG-56-001-RGBA)

- Sandia Service Yard (CAS 03-58-001-03FN)

- Gun Propellant Burn Area (CAS 09-54-001-09L2)

The four CASs that comprise CAU 490, Station 44 Burn Area, are located at the TTR. The TTR, included in the Nellis Air Force Range, is approximately 140 miles (mi) northwest of Las Vegas, Nevada (Figure 1-1). The Fire Training Area (FTA) is located southwest of Area 3, Station 44 Burn Area is located west of Main Lake, Sandia Service Yard (SSY) is located north of the northwest corner of Area 3, and the Gun Propellant Burn Area (GPBA) is located south of the Area 9 Compound on the TTR (Figure 1-2).

\subsection{Purpose}

This CADD identifies and provides a rationale for the selection of a recommended corrective action alternative for each CAS within the CAU. The need for evaluation of corrective action alternatives is based on process knowledge and the results of investigative activities conducted in accordance with the Corrective Action Investigation Plan (CAIP) for Corrective Action Unit 490: Station 44 Burn Area, Tonopah Test Range, Nevada (DOE/NV, 2000), which is described in Appendix A. 


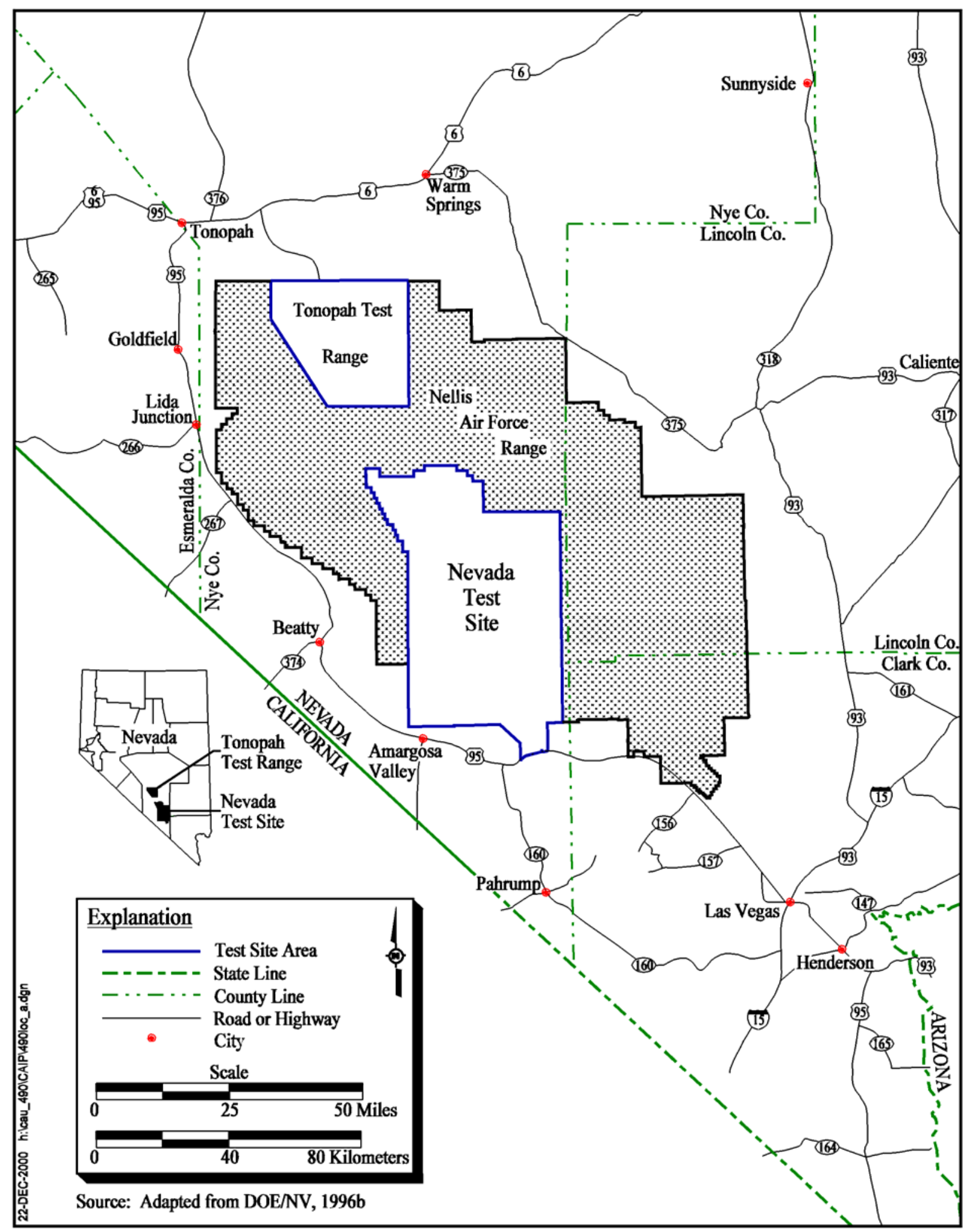

Figure 1-1

Tonopah Test Range Location Map 


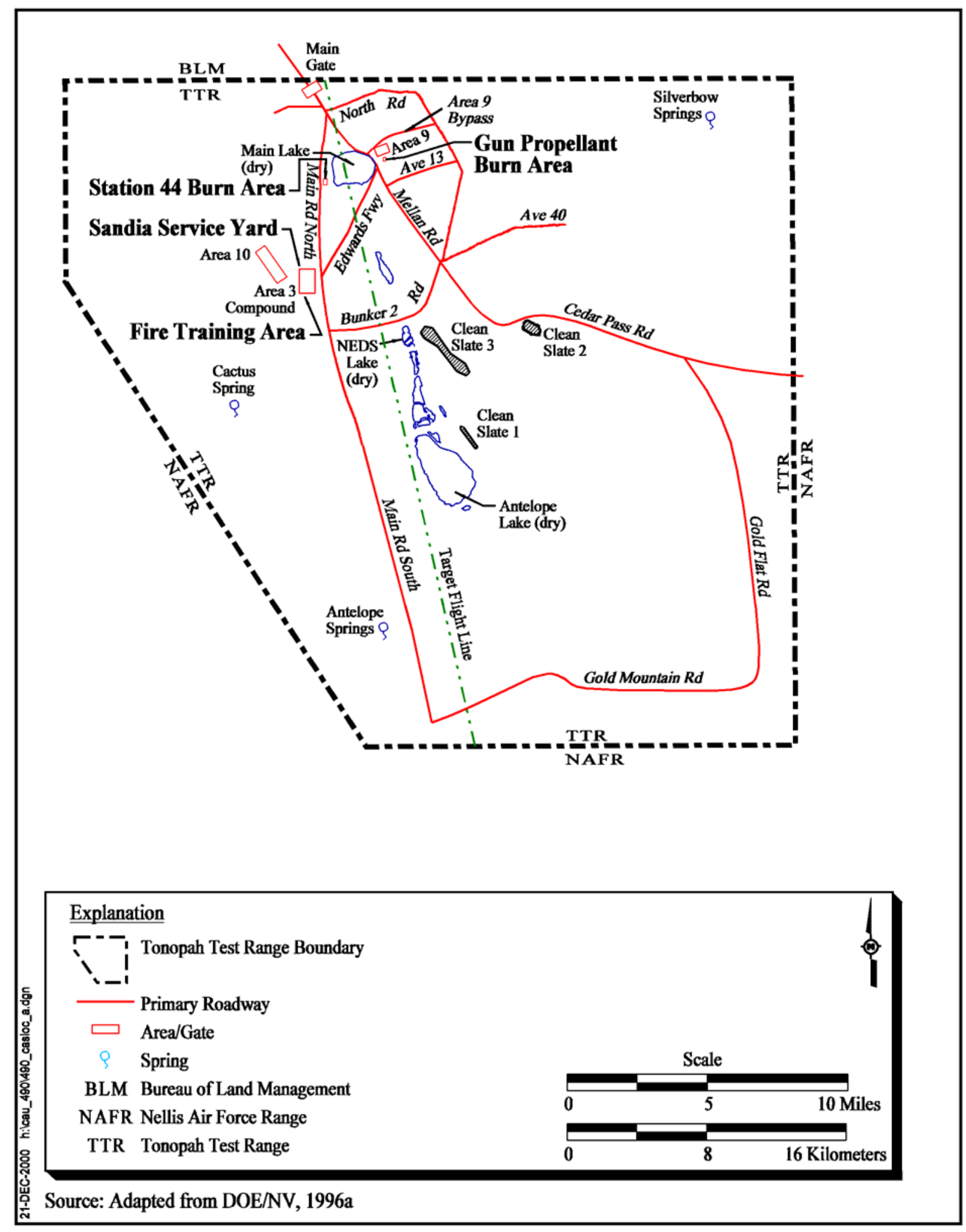

Figure 1-2 Approximate Locations of CAU 490 CASs, Tonopah Test Range 


\subsection{Scope}

The scope of this CADD consists of the following:

- Develop corrective action objectives.

- Identify corrective action alternative screening criteria.

- Develop corrective action alternatives.

- Perform detailed and comparative evaluations of corrective action alternatives in relation to corrective action objectives and screening criteria.

- Recommend and justify a preferred corrective action alternative for each CAS within the CAU.

\section{$1.3 \quad C A D D$ Contents}

This CADD is divided into the following sections:

Section 1.0 - Introduction: summarizes the purpose, scope, and contents of this CADD.

Section 2.0 - Corrective Action Investigation Summary: describes the investigation field activities, the results of the investigation, and the need for corrective action.

Section 3.0 - Evaluation of Alternatives: documents steps taken to determine a preferred corrective action alternative.

Section 4.0 - Recommended Alternative: presents the preferred corrective action alternative and the rationale for its selection based on the corrective action objectives and alternative screening criteria.

Section 5.0 - References: provides a list of all referenced documents.

Appendix A: Corrective Action Investigation Report for CAU 490: Station 44 Burn Area, Tonopah Test Range, Nevada

Appendix B: Cost Estimates for CAU 490 
Appendix C: Evaluation of Risk

Appendix D: Responses to the Nevada Division of Environmental Protection (NDEP) Comments

All work was performed in accordance with the following documents:

- Corrective Action Investigation Plan for Corrective Action Unit 490: Station 44 Burn Area, Tonopah Test Range, Nevada, Rev. 0, DOE/NV--613 (DOE/NV, 2000)

- Industrial Sites Quality Assurance Project Plan, Rev. 1, DOE/NV--372 (DOE/NV, 1996c)

- Corrective Action Unit Work Plan for the Tonopah Test Range, Rev. 0, DOE/NV--443 (DOE/NV, 1996a)

- FFACO (FFACO, 1996)

- Project Management Plan (DOE/NV, 1994) 


\subsection{Corrective Action Investigation Summary}

The following sections describe and summarize the results of the investigation activities conducted at CAU 490. For detailed investigation results, please refer to Appendix A.

\subsection{Investigation Activities}

Corrective action investigation activities were performed as set forth in the CAIP (DOE/NV, 2000) between July 19 and August 17, 2000. Two methods were utilized during the investigation of CAU 490: excavation and direct-push. The objectives of the investigation include:

- Identify the presence and concentrations of contaminants of potential concern (COPCs) at the CAU.

- Determine the vertical and lateral extent of COPCs.

- Provide sufficient information and data to develop appropriate corrective actions for each CAS.

Investigation activities were conducted at each CAS. These activities are summarized below:

Fire Training Area (CAS 03-56-001-03BA)

- Excavated two linear trenches utilizing a backhoe.

- Field screened soil samples for volatile organic compounds (VOCs) (using a Photoionization detection [PID]) and total petroleum hydrocarbons (TPH) (using the Hanby test kit).

- Collected surface and subsurface soil samples for laboratory analyses.

- Analyzed all environmental samples for total VOCs, total semivolatile organic compounds (SVOCs), total Resource Conservation and Recovery Act (RCRA) metals and zinc, and TPH (diesel-range organics). Additionally, 25 percent of the samples were submitted for gamma spectrometry analysis for waste management purposes.

Station 44 Burn Area (CAS RG-56-001-RGBA)

- Utilized direct-push (Geoprobe $\left.{ }^{\circledR}\right)$ at four locations. 
- $\quad$ Field screened soil samples for VOCs (using a PID) and TPH (using the Hanby test kit).

- Collected surface and subsurface soil samples for laboratory analyses.

- Analyzed all environmental samples for total VOCs, total SVOCs, total RCRA metals and zinc, and TPH (diesel-range organics). Additionally, 25 percent of the samples were submitted for gamma spectrometry analysis for waste management purposes.

Sandia Service Yard (CAS 03-58-001-03FN)

- $\quad$ Utilized direct-push $\left(\mathrm{Geoprobe}^{\circledR}\right)$ at 26 locations.

- $\quad$ Field screened soil samples for VOCs (using a PID) and TPH (using the Hanby test kit).

- Collected surface and subsurface soil samples for laboratory analyses.

- Analyzed all environmental samples for total VOCs, total SVOCs, total RCRA metals, total pesticides, polychlorinated biphenyls (PCBs), and TPH (gasoline- and diesel-range organics). Additionally, 25 percent of the samples were submitted for gamma spectrometry analysis for waste management purposes.

Gun Propellant Burn Area (CAS 09-54-001-09L2)

- Excavated at 24 locations utilizing a backhoe.

- Field screened soil samples for VOCs (using a PID), nitroglycerine, nitroguanidine, Royal Demolition Explosive (RDX), (Cyclotrimethylene Trinitramine), and nitrocellulose using a colorimetric field test kit; and alpha/beta emitters using an Electra.

- Collected surface and subsurface soil samples for laboratory analyses. Collected soil for geotechnical analyses.

- Analyzed all environmental samples for total VOCs, total SVOCs, total RCRA metals, TPH (diesel-range organics), nitroglycerine, nitroguanidine, nitroaromatics and nitoramines, nitrocellulose, plutonium, and isotopic uranium.

\subsection{Results}

Details of the methods used and results found during the investigation are presented in Appendix A. Analysis of the data generated for each CAS from corrective action investigation activities at CAU 490 indicates the following: 
Fire Training Area (CAS 03-56-001-03BA)

- All concentrations of total VOCs and total SVOCs in soil samples were below the Preliminary Action Levels (PALs) outlined in the CAIP (DOE/NV, 2000). Additionally, gamma spectrometry analysis results for soil samples are not considered to be statistically different from their respective established background levels and, therefore, are below PALs.

- All concentrations of total RCRA metals and zinc in soil samples were below PALs established in the CAIP (DOE/NV, 2000), except for arsenic. Although the concentrations of arsenic exceeded the PAL of 2.7 milligrams per kilogram $(\mathrm{mg} / \mathrm{kg})$, the concentrations are considered representative of ambient conditions for the TTR.

- The arsenic concentration at FTA ranged from $3.3 \mathrm{mg} / \mathrm{kg}$ to $10.0 \mathrm{mg} / \mathrm{kg}$. The PAL of $2.7 \mathrm{mg} / \mathrm{kg}$ is lower than the 7 to 8 parts per million $(\mathrm{ppm})(\mathrm{mg} / \mathrm{kg})$ mean concentration of arsenic in silt from the Nellis Air Force Range (NBMG, 1998; Moore, 1999) and lower than the concentration range of 6 to $43 \mathrm{mg} / \mathrm{kg}$ in soils from locations near the TTR (SNL, 1999). Data from previous sampling efforts in or near Area 3 also reveal arsenic concentrations as high as $24.1 \mathrm{mg} / \mathrm{kg}$ from undisturbed locations (DOE/NV, 1998).

- Total petroleum hydrocarbons exceeded the NDEP action level of $100 \mathrm{mg} / \mathrm{kg}$ for TPH-diesel in 5 of the 18 soil samples collected. The 5 samples that exceeded the action level were collected from two of the five locations within the excavations.

\section{Station 44 Burn Area (CAS RG-56-001-RGBA)}

- All concentrations of total VOCs, total SVOCs, and TPH (diesel-range organics) in soil samples were below the PALs outlined in the CAIP. Additionally, gamma spectrometry analysis results for soil samples are not considered to be statistically different from their respective established background levels and, therefore, are below PALs.

- All concentrations of total RCRA metals and zinc in soil samples were below PALs established in the CAIP, except for arsenic. Although the concentrations of arsenic exceeded the PAL of $2.7 \mathrm{mg} / \mathrm{kg}$, the concentrations are considered representative of ambient conditions for the TTR.

- The arsenic concentration at STA44 ranged from $3.7 \mathrm{mg} / \mathrm{kg}$ to $7.0 \mathrm{mg} / \mathrm{kg}$. The PAL of $2.7 \mathrm{mg} / \mathrm{kg}$ is lower than the 7 to $8 \mathrm{ppm}(\mathrm{mg} / \mathrm{kg})$ mean concentration of arsenic in silt from the Nellis Air Force Range (NBMG, 1998; Moore, 1999) and lower than the concentration range of 6 to $43 \mathrm{mg} / \mathrm{kg}$ in soils from locations near the TTR (SNL, 1999). Data from previous sampling efforts in or near Area 3 also reveal arsenic concentrations as high as $24.1 \mathrm{mg} / \mathrm{kg}$ from undisturbed locations (DOE/NV, 1998). 
- All concentrations of total VOCs, total SVOCs, total pesticides, and total PCBs in soil samples were below the PALs outlined in the CAIP. Additionally, gamma spectrometry analysis results for soil samples are not considered to be statistically different from their respective established background levels and, therefore, are below PALs.

- All concentrations of total RCRA metals in soil samples were below PALs established in the CAIP, except for arsenic. Although the concentrations of arsenic exceeded the PAL of $2.7 \mathrm{mg} / \mathrm{kg}$, the concentrations are considered representative of ambient conditions for the TTR.

- The arsenic concentration at SSY ranged from $3.2 \mathrm{mg} / \mathrm{kg}$ to $7.3 \mathrm{mg} / \mathrm{kg}$. The PAL of $2.7 \mathrm{mg} / \mathrm{kg}$ is lower than the 7 to $8 \mathrm{ppm}(\mathrm{mg} / \mathrm{kg})$ mean concentration of arsenic in silt from the Nellis Air Force Range (NBMG, 1998; Moore, 1999) and lower than the concentration range of 6 to $43 \mathrm{mg} / \mathrm{kg}$ in soils from locations near the TTR (SNL, 1999). Data from previous sampling efforts in or near Area 3 also reveal arsenic concentrations as high as $24.1 \mathrm{mg} / \mathrm{kg}$ from undisturbed locations (DOE/NV, 1998).

- Total petroleum hydrocarbons exceeded the NDEP action level of $100 \mathrm{mg} / \mathrm{kg}$ for TPH-diesel in 7 of the 55 near-surface soil samples collected. The 7 samples that exceeded the action level were collected from 5 of the 26 locations. The NDEP action level for TPH-gasoline was not exceeded at any of the SSY locations.

Gun Propellant Burn Area (CAS 09-54-001-09L2)

- All concentrations of total VOCs, total SVOCs, TPH (diesel-range organics), nitroglycerine, nitroguanidine, nitroaromatics and nitoramines, and nitrocellulose in soil samples were below the PALs outlined in the CAIP. Additionally, isotopic plutonium and isotopic uranium analysis results for soil samples are not considered to be statistically different from their respective established background levels and, therefore, are below PALs.

- All concentrations of total RCRA metals in soil samples were below PALs established in the CAIP, except for arsenic. Although the concentrations of arsenic exceeded the PAL of $2.7 \mathrm{mg} / \mathrm{kg}$, the concentrations are considered representative of ambient conditions for the TTR.

- The arsenic concentration at GPBA ranged from $2.6 \mathrm{mg} / \mathrm{kg}$ to $9.2 \mathrm{mg} / \mathrm{kg}$. The PAL of $2.7 \mathrm{mg} / \mathrm{kg}$ is lower than the 7 to $8 \mathrm{ppm}(\mathrm{mg} / \mathrm{kg})$ mean concentration of arsenic in silt from the Nellis Air Force Range (NBMG, 1998; Moore, 1999) and lower than the concentration range of 6 to $43 \mathrm{mg} / \mathrm{kg}$ in soils from locations near the TTR (SNL, 1999). Data from previous sampling efforts in or near Area 3 also reveal arsenic concentrations as high as $24.1 \mathrm{mg} / \mathrm{kg}$ from undisturbed locations (DOE/NV, 1998). 
- Because of an elevated level of total chromium (140 mg/kg for sample GPB00111), the Toxicity Characteristic Leaching Procedure (TCLP) for this sample was performed. The TCLP result is nondetect.

- Analytical results from the Jet Assisted Take Off (JATO) rocket resin sample (GPB00124) collected from the exterior surface indicated detection of COPCs including: calcium; aluminum; antimony; magnesium; iron; lead; uranium-235; uranium-238; di-n-butylphthalate; 1, 4-dichlorobenzene; 1,2, 4-trichlorobenzene; 1,2-dichlorobenzene; 3-nitrotoluene; 2,4-dinitrotoluene; 2-amino-4,6-dnt; nitrobenzene; nitroglycerin; trichlorofluoromethane; acetone; diesel-range organics; selenium; zinc; chromium; copper; and manganese. The analytical results of the JATO rocket resin were inconclusive based on SVOCs analysis and were resampled (GPB00700) for TCLP SVOC analysis to determine if it was a nonhazardous material. The results were nondetect. The JATO rocket was removed from this CAS for proper disposal.

\subsection{Need for Corrective Action}

Analytes detected during the corrective action investigation were evaluated against PALs to determine contaminants of concern (COCs) for CAU 490. Five soil samples exceeded PALs for TPH-diesel at Fire Training Area (CAS 03-56-001-03BA); and seven soil samples exceeded PALs for TPH-diesel at Sandia Service Yard (CAS 03-58-001-03FN).

There were no COCs identified in soil at the Gun Propellant Burn Area (CAS 09-54-001-09L2) or the Station 44 Burn Area (CAS RG-56-001-RGBA). All subsurface debris identified as geophysical anomalies was removed. There is no need for corrective actions at these sites. 


\subsection{Evaluation of Alternatives}

The purpose of this section is to present the corrective action objectives for CAU 490, describe the general standards and decision factors used to screen the corrective action alternatives, and develop and evaluate a set of corrective action alternatives that could be used to meet the corrective action objectives.

\subsection{Corrective Action Objectives}

The corrective action objectives are media-specific goals for protecting human health and the environment. Based on the potential exposure pathways (see Section 3.1.2), the following corrective action objectives have been identified for the FTA and SSY at CAU 490:

- Prevent or mitigate exposure to surface and near-surface soil containing COCs at concentrations exceeding PALs as defined in the CAIP (DOE/NV, 2000).

- Prevent spread of COCs beyond the CAU.

- Reduce potential exposure to current and future site workers and reduce the risk to human health and the environment.

\subsubsection{Contaminants of Concern}

Contaminants of potential concern were determined in the Data Quality Objectives (DQO) process as listed in the CAIP (DOE/NV, 2000). Analytical results obtained from the corrective action investigation were evaluated to determine if COPCs were detected above PALs, and identify COCs for CAU 490 that must be addressed by corrective action. Based on the results of this evaluation, the PALs were exceeded in soil samples for TPH (diesel range) at FTA and SSY. No other COCs were identified at CAU 490.

\subsubsection{Potential Exposure Pathways}

As identified in the CAIP, the future use for the CAU is assumed to be similar to current use (industrial). As part of the CAIP (DOE/NV, 2000), a conceptual model was developed which identified the potential exposure mechanism as disturbance (excavation) of contaminated soil by 
site workers. This implies a potential exposure pathway through ingestion, inhalation, and dermal contact with contaminated soil under industrial scenarios. Depth to groundwater beneath the Area 3 compound is estimated at 360 to 394 feet (ft) below ground surface (bgs). The groundwater flow direction is generally to the north-northwest at Area 3 (DOE/NV, 1996a). These factors, along with others presented in Section 3.3, support the determination that contaminant migration to groundwater is not considered to be an exposure pathway.

\subsection{Screening Criteria}

The screening criteria used to evaluate and select the preferred corrective action alternatives are identified in the U.S. Environmental Protection Agency (EPA) Guidance on RCRA Corrective Action Decision Documents (EPA, 1991) and the Final RCRA Corrective Action Plan (EPA, 1994).

Corrective action alternatives will be evaluated based on four general corrective action standards and five remedy selection decision factors. All corrective action alternatives must meet the general standards to be selected for evaluation using the remedy selection decision factors.

The general corrective action standards are as follows:

- Protection of human health and the environment

- Compliance with media cleanup standards

- Control the source(s) of the release

- Compliance with applicable federal, state, and local standards for waste management

The remedy selection decision factors are as follows:

- Short-term reliability and effectiveness

- Reduction of toxicity, mobility, and/or volume

- Long-term reliability and effectiveness

- Feasibility

- Cost

\subsubsection{Corrective Action Standards}

The following text describes the corrective action standards used to evaluate the corrective action alternatives. 


\section{Protection of Human Health and the Environment}

Protection of human health and the environment is a general mandate of the RCRA statute (EPA, 1994). This mandate requires that the corrective action include any protective measures that are necessary. These measures may or may not be directly related to media cleanup, source control, or management of wastes. The corrective action alternatives are evaluated for the ability to meet corrective action objectives as defined in Section 3.1.

\section{Compliance with Media Cleanup Standards}

Each corrective action alternative must have the ability to meet the proposed media cleanup standards as set forth in applicable state and federal regulations, and as specified in the CAIP (DOE/NV, 2000). For this CAU, the EPA's Region 9 Preliminary Remediation Goals (PRGs), which are derived from the Integrated Risk Information System, are the basis for establishing the PALs for chemical contaminants under Nevada Administrative Code (NAC) 445A.2272 (NAC, 1998b). The PAL for petroleum substances in soil is $100 \mathrm{mg} / \mathrm{kg}$ in accordance with NAC 445A.2272 (NAC, 1998b). The PALs for radiological contaminants are based on background concentrations. Laboratory results above PALs indicate the presence of COPCs at levels that may require corrective action.

\section{Control the Source(s) of the Release}

An objective of a corrective action remedy is to stop further environmental degradation by controlling or eliminating additional releases that may pose a threat to human health and the environment. Unless source control measures are taken, efforts to clean up releases may be ineffective or, at best, will essentially involve a perpetual cleanup. Therefore, each corrective action alternative must use an effective source control program to ensure the long-term effectiveness and protectiveness of the corrective action.

\section{Comply with Applicable Federal, State, and Local Standards for Waste Management}

During implementation of any corrective action alternative, all waste management activities must be conducted in accordance with applicable state and federal regulations (e.g., Nevada Revised Statutes [NRS] 459.400 - 459.600, "Disposal of Hazardous Waste” [NRS, 1995]; 40 Code of Federal Regulations [CFR] 260 - 282, "RCRA Regulations" [CFR, 1998]; NAC 444, "Sanitation" 
[NAC, 1998a]; and NAC 459.9974, "Disposal and Evaluation of Contaminated Soil"

[NAC, 1998c]). The requirements for management of the waste, if any, derived from the corrective action will be determined based on applicable state and federal regulations, field observations, process knowledge, characterization data, and data collected and analyzed during corrective action implementation. Administrative controls (e.g., decontamination procedures and corrective action strategies) will minimize waste generated during site corrective action activities. Decontamination activities will be performed in accordance with approved procedures and will be designated according to the COCs present at the CAU.

\subsubsection{Remedy Selection Decision Factors}

The following text describes the remedy selection decision factors used to evaluate the corrective action alternatives.

\section{Short-Term Reliability and Effectiveness}

Each corrective action alternative must be evaluated with respect to its effects on human health and the environment during implementation of the corrective action. The following factors will be addressed for each alternative:

- Protection of the community from potential risks associated with implementation, such as fugitive dusts, transportation of hazardous materials, and explosion

- Protection of remediation workers during implementation

- Environmental impacts that may result from implementation

- The amount of time until the corrective action objectives are achieved

\section{Reduction of Toxicity, Mobility, and/or Volume}

Each corrective action alternative must be evaluated for its ability to reduce the toxicity, mobility, and/or volume of the contaminated media. Reduction in toxicity, mobility, and/or volume refers to changes in one or more characteristics of the contaminated media by the use of corrective measures that decrease the inherent threats associated with that media. 


\section{Long-Term Reliability and Effectiveness}

Each corrective action alternative must be evaluated in terms of risk remaining at the CAU after the corrective action alternative has been implemented. The primary focus of this evaluation is on the extent and effectiveness of the controls that may be required to manage the risk posed by treatment residuals and/or untreated wastes.

\section{Feasibility}

The feasibility criterion addresses the technical and administrative feasibility of implementing a corrective action alternative and the availability of services and materials needed during implementation. Each corrective action alternative must be evaluated for the following criteria:

- Construction and Operation. Refers to the feasibility of implementing a corrective action alternative given the existing set of waste and site-specific conditions.

- Administrative Feasibility. Refers to the administrative activities needed to implement the corrective action alternative (e.g., permits, public acceptance, rights of way, off-site approval).

- Availability of Services and Materials. Refers to the availability of adequate off-site and on-site treatment, storage capacity, disposal services, necessary technical services and materials, and prospective technologies for each corrective action alternative.

\section{Cost}

Costs for each alternative are estimated for comparison purposes only. The cost estimate for each corrective action alternative includes both capital and operation and maintenance costs, as applicable. The following is a brief description of each component:

- Capital Costs - these costs include both direct and indirect costs. Direct costs may consist of materials, labor, mobilization, demobilization, site preparation, construction materials, equipment purchase and rental, sampling and analysis, waste disposal, and health and safety measures. Indirect costs include such items as engineering design, permits and/or fees, start-up costs, and any contingency allowances.

- Operation and Maintenance - these costs include labor, training, sampling and analysis, maintenance materials, utilities, and health and safety measures.

Cost summaries for this CADD are provided in Appendix C. 


\subsection{Development of Corrective Action Alternatives}

This section identifies and briefly describes the viable corrective action technologies and the corrective action alternatives considered for the affected media. Based on the review of existing data, future use, and current operations at the TTR, the following alternatives have been developed for consideration at CAU 490:

- Alternative 1 - No Further Action

- Alternative 2 - Closure In Place - With Administrative Controls

- Alternative 3 - Clean Closure by Excavation and Disposal

Other technologies, such as bioremediation and a surface cap, were considered. A surface cap will not be necessary because the remaining COCs are located beneath the surface at the FTA and at relatively low concentrations. Bioremediation was also considered; however, it would not be necessary because of the limited volume and concentrations of contaminated material. These alternatives will not receive further consideration in this CADD.

The following evaluation of NAC 445A.227 (2) (a-k) (NAC, 1998b) supports the protection of groundwater from COCs at CAU 490:

a. The depth to groundwater is 360 to $394 \mathrm{ft}$ around the Area 3 Compound (DOE/NV, 1996b). Activities at FTA and SSY have ceased; therefore, no driving force exists to contribute to contaminant migration. The precipitation for the area (5 to 6 inches [in.] annually) (DOE/NV, 1996a) does not significantly influence the movement of the contaminants. Field screening and analytical data indicate that COCs are confined primarily from the surface to $13.0 \mathrm{ft}$ bgs at FTA and to $4.0 \mathrm{ft}$ bgs at SSY. This indicates minimal vertical migration has occurred in the past and will be negligible in the future.

b. The distance to the nearest drinking water well (Sandia 6) is approximately 2,000 ft southeast of the center of the Area 3 Compound. Groundwater generally flows to the northwest (DOE/NV, 1996b). Contaminants would be required to travel the vertical distance to the groundwater and travel through the groundwater in a direction opposite normal groundwater flow to the radius of influence of the well. Based on the concentrations and volumes of contamination, the likelihood of any impacts to the well is minimal.

c. Geotechnical analysis of soil samples was not performed at any of the CASs.

d. Annual precipitation averages 5 to 6 in. and annual evaporation is between 58 and 66 in. (DOE/NV, 1996b). The high evaporation and low precipitation rates create a negative water 
balance for the area; therefore, no driving force associated with precipitation is available to mobilize COCs vertically.

e. The types of regulated substances released are diesel-range petroleum hydrocarbons. Downward migration of COCs is slowed by the following parameters:

- Volume of release - small volumes of COCs were released over a long period of time rather than a large volume over a short duration.

- Soil saturation - the soil tends to be very dry, especially near the surface where the COCs are concentrated.

- Soil particle adsorption/desorption - contaminants tend to adsorb to the soil particles with little desorption as suggested by the limited vertical migration of COCs.

f. The dimensions of petroleum hydrocarbon-impacted soil at FTA are approximately $15 \times 15 \times 15 \mathrm{ft}$. The dimensions of the petroleum hydrocarbon-impacted soil at the three SSY locations are approximately $60 \times 30 \times 4 \mathrm{ft}, 65 \times 45 \times 2 \mathrm{ft}$, and $25 \times 25 \times 4 \mathrm{ft}$.

g. Presently, the FTA and SSY are located on a government-controlled facility. The TTR is a restricted area that is guarded on a 24-hour, 365-day per year basis; unauthorized personnel are not admitted to the facility. The future use for the FTA and SSY are expected to be similar to current industrial, administrative, and research-related activities.

h. Preferred routes of vertical migration are nonexistent since the sources have been eliminated and driving forces are not viable due to the static conditions at this CAU. Inadvertent intrusion is the only pathway from the contaminants to potential receptors.

i. Operations at the CAU have been terminated. Activities were last conducted at FTA in the mid-1980s and SSY in the early 1990s.

j. The potential for a hazard related to fire, vapor, or explosion is nonexistent for the COCs at the CAU.

k. No other site-specific factors are known at this time.

Based on this evaluation, impacts to groundwater are not expected. Therefore, groundwater monitoring is not proposed for this CAU and is not considered an element of the alternatives. 


\subsubsection{Alternative 1 - No Further Action}

Under the No Further Action Alternative, no corrective action activities will be implemented. This alternative is a baseline case with which to compare and assess the other corrective action alternatives and their ability to meet the corrective action standards. This alternative does not meet the corrective action objectives for CAU 490 because no actions are taken to prevent exposure to the COC. This alternative will not be compared to the other alternatives using the selection decision factors for these CASs.

\subsubsection{Alternative 2 - Closure in Place with Administrative Controls}

Alternative 2 does not include the removal or disposal of soil and no verification sampling will be performed. Four areas will be fenced, one at FTA and three at SSY. Appropriate signage will be installed. Alternative 2 will utilize administrative controls to prevent inadvertent contact with COCs. These controls would consist of use restrictions to prevent unauthorized intrusive activities. The future use of the CAU would be restricted from any activity that would alter or modify the containment control unless appropriate concurrence was obtained from NDEP.

\subsubsection{Alternative 3 - Clean Closure by Excavation and Disposal}

Alternative 3 includes excavating and disposing of contaminated soil from FTA and SSY with diesel-range petroleum hydrocarbon concentrations greater than PALs. Four areas will be excavated, one at FTA and three at SSY. At FTA, TPH-impacted soil that does not extend into the CAU 424 Use Restriction Area, Landfill A3-8, CAS 03-08-002-038 will be excavated. The estimated volume of TPH-impacted soil to be excavated is approximately 125 cubic yards (see Figure A.2-1 in Appendix A for a graphic representation). The estimated volume of TPH-impacted soil to be excavated at the three SSY sites is approximately 275 cubic yards, 225 cubic yards, and 100 cubic yards (see Figure A.2-3 in Appendix A for a graphic representation). All contaminated, excavated material will be disposed of at the Nevada Test Site (NTS) Hydrocarbon Landfill. Verification samples will be collected and submitted for TPH analyses. This will ensure complete removal of contaminated soil at concentrations exceeding the PALs. The four excavations will be backfilled with clean soil from the Area 3 Borrow Pit. No fencing or signage will be posted. Details of the plans for Clean Closure by Excavation and Disposal activities to be performed therein 
will be addressed in the Corrective Action Plan. The results of these activities, as well as other closure activities, will be addressed in detail in the Closure Report.

The CAU 490 site will be closed in accordance with NAC 445A (NAC, 1998b), as described in this section.

\subsubsection{CAU 424 Use Restriction Area}

A limited amount of TPH-impacted soil extends into the CAU 424 Use Restriction Area Landfill A3-8, CAS 03-08-002-A308. As part of the Clean Closure by Excavation and Disposal alternative for FTA, the Use Restriction Area will not be accessed. If TPH-impacted soils are found at the boundary of the closed CAU 424 Use Restriction Area, a Record of Technical Change for the CAU 424 Closure Report will be required.

\subsection{Evaluation and Comparison of Alternatives}

The general corrective action standards and remedy selection decision factors described in Section 3.2 were used to conduct detailed and comparative analyses of each corrective action alternative. The advantages and disadvantages of each alternative were assessed to select a preferred alternative for CAU 490. Table 3-1 presents a summary of the detailed analysis of the alternatives. Table 3-2 presents the comparative analysis of the alternatives. Cost summaries are provided in Appendix C. 
Table 3-1

Detailed Evaluation of Alternatives

(Page 1 of 3 )

\begin{tabular}{|c|c|c|c|}
\hline Evaluation Criteria & $\begin{array}{c}\text { Alternative } 1 \\
\text { No Further Action }\end{array}$ & $\begin{array}{c}\text { Alternative } 2 \\
\text { Closure in Place with Administrative } \\
\text { Controls }\end{array}$ & $\begin{array}{c}\text { Alternative } 3 \\
\text { Clean Closure by Excavation and } \\
\text { Disposal }\end{array}$ \\
\hline \multicolumn{4}{|c|}{ Closure Standards } \\
\hline $\begin{array}{l}\text { Protection of Human Health } \\
\text { and the Environment }\end{array}$ & $\begin{array}{l}\text { Does not meet corrective action } \\
\text { objective of preventing or mitigating } \\
\text { exposure to surface and subsurface } \\
\text { soil containing COCs at } \\
\text { concentrations exceeding PALs. } \\
\text { - Does not prevent spread of COCs. } \\
\text { - NAC } 445 A .227(2)(a-k) \text { analysis } \\
\text { shows the contaminants are not } \\
\text { expected to impact groundwater. } \\
\text { No worker exposure associated with } \\
\text { implementation. }\end{array}$ & $\begin{array}{l}\text { - } \quad \text { Meets corrective action objectives. } \\
\text { - } \text { Prevents inadvertent intrusion into } \\
\text { the contaminated soil zone. } \\
\text { - } \text { ho risk to workers associated with } \\
\text { contact with impacted media during } \\
\text { excavation and transportation } \\
\text { activities. } \\
\text { - Low risk to public because of remote } \\
\text { location and controlled access to the } \\
\text { TTR. } \\
\text { NAC 445A.227 (2) (a-k) analysis } \\
\text { shows the contaminants are not } \\
\text { expected to impact groundwater. }\end{array}$ & $\begin{array}{l}\text { - } \quad \text { Meets corrective action objectives. } \\
\text { how risk to workers associated with } \\
\text { coavy equipment and potential } \\
\text { excavation and transportation } \\
\text { activities. } \\
\text { - Low risk to public due to remote } \\
\text { location and controlled access to } \\
\text { TTR. } \\
\text { Moving contaminated soil to an } \\
\text { appropriate disposal facility mitigates } \\
\text { exposure to impacted media after } \\
\text { closure. }\end{array}$ \\
\hline $\begin{array}{l}\text { Compliance with Media } \\
\text { Cleanup Standards }\end{array}$ & $\begin{array}{l}\text { Does not comply with media cleanup } \\
\text { standards because COCs remain at } \\
\text { levels above PALs. } \\
\text { NAC 445A.227 (2) (a-k) analysis } \\
\text { shows the contaminants are not } \\
\text { expected to impact groundwater. }\end{array}$ & $\begin{array}{l}\text { - Complies with media cleanup } \\
\text { standards by eliminating exposure } \\
\text { pathways. } \\
\text { NAC } 445 A .227(2)(a-k) \text { analysis } \\
\text { shows the contaminants are not } \\
\text { expected to impact groundwater. }\end{array}$ & $\begin{array}{l}\text { - Complies with media cleanup } \\
\text { standards because soil containing } \\
\text { COCs at concentrations exceeding } \\
\text { PALs will be excavated and disposed } \\
\text { of at an appropriate facility. } \\
\text { - Removal of COC concentrations } \\
\text { exceeding PALs will be verified with } \\
\text { confirmation sampling. }\end{array}$ \\
\hline $\begin{array}{l}\text { Control the Source(s) of } \\
\text { Release }\end{array}$ & $\begin{array}{l}\text { The contaminant sources to CAU } 490 \\
\text { have been discontinued. }\end{array}$ & $\begin{array}{l}\text { The contaminant sources to CAU } 490 \\
\text { have been discontinued. }\end{array}$ & $\begin{array}{l}\text { The contaminant sources to CAU } 490 \\
\text { have been discontinued. }\end{array}$ \\
\hline
\end{tabular}


Table 3-1

Detailed Evaluation of Alternatives

(Page 2 of 3 )

\begin{tabular}{|c|c|c|c|}
\hline Evaluation Criteria & $\begin{array}{c}\text { Alternative } 1 \\
\text { No Further Action }\end{array}$ & $\begin{array}{c}\text { Alternative } 2 \\
\text { Closure in Place with Administrative } \\
\text { Controls }\end{array}$ & $\begin{array}{c}\text { Alternative } 3 \\
\text { Clean Closure by Excavation and } \\
\text { Disposal }\end{array}$ \\
\hline $\begin{array}{l}\text { Comply with Applicable } \\
\text { Federal, State, and Local } \\
\text { Standards for Waste } \\
\text { Management }\end{array}$ & No waste generated & No additional waste will be generated. & $\begin{array}{l}\text { All waste (primarily contaminated soil } \\
\text { and disposable personal protective } \\
\text { equipment) will be handled and disposec } \\
\text { of in accordance with applicable } \\
\text { standards. }\end{array}$ \\
\hline \multicolumn{4}{|c|}{ Remedy Selection Decision Factors } \\
\hline $\begin{array}{l}\text { Short-Term Reliability and } \\
\text { Effectiveness }\end{array}$ & Not evaluated & $\begin{array}{l}\text { Public protected by remote location } \\
\text { and TTR site access controls. } \\
\text { Implementation should not require an } \\
\text { extended period of time. }\end{array}$ & $\begin{array}{l}\text { - Low risk to workers associated with } \\
\text { heavy equipment and potential } \\
\text { contact with impacted media during } \\
\text { excavation and transportation } \\
\text { activities. } \\
\text { - } \quad \text { Public protected by remote location } \\
\text { and TTR site access controls. } \\
\text { Environmental impacts are not } \\
\text { anticipated due to implementation. } \\
\text { Appropriate measures will be taken } \\
\text { at the CAU to protect desert } \\
\text { tortoises. } \\
\text { Implementation should not require an } \\
\text { extended period of time. }\end{array}$ \\
\hline $\begin{array}{l}\text { Reduction of Toxicity, } \\
\text { Mobility, and/or Volume }\end{array}$ & Not evaluated & $\begin{array}{l}\text { The mobility of the remaining } \\
\text { subsurface COCs is effectively } \\
\text { eliminated by administrative controls } \\
\text { and lack of viable driving forces. }\end{array}$ & $\begin{array}{l}\text { Clean closure would effectively } \\
\text { eliminate associated toxicity, } \\
\text { mobility, and volume of wastes at } \\
\text { CAU } 490 \text {. } \\
\text { Proper disposal of the waste will } \\
\text { result in an ultimate reduction of } \\
\text { mobility. }\end{array}$ \\
\hline
\end{tabular}


Table 3-1

Detailed Evaluation of Alternatives

(Page 3 of 3 )

\begin{tabular}{|c|c|c|c|}
\hline Evaluation Criteria & $\begin{array}{c}\text { Alternative } 1 \\
\text { No Further Action }\end{array}$ & $\begin{array}{c}\text { Alternative } 2 \\
\text { Closure in Place with Administrative } \\
\text { Controls }\end{array}$ & $\begin{array}{c}\text { Alternative } 3 \\
\text { Clean Closure by Excavation and } \\
\text { Disposal }\end{array}$ \\
\hline $\begin{array}{l}\text { Long-Term Reliability and } \\
\text { Effectiveness }\end{array}$ & Not evaluated & $\begin{array}{l}\text { - Controls inadvertent intrusion to } \\
\text { remaining COCs. } \\
\text { - Administrative controls must be } \\
\text { maintained. }\end{array}$ & $\begin{array}{l}\text { - All risk will be eliminated upon } \\
\text { completion. } \\
\text { - No maintenance required } \\
\text { - } \text { CAU } 490 \text { clean closed. } \\
\text { Moving contaminated soil to an } \\
\text { appropriate disposal facility } \\
\text { addresses the persistent adsorption } \\
\text { of contaminants to the soil. }\end{array}$ \\
\hline Feasibility & Not evaluated & $\begin{array}{l}\text { - Easily implemented. } \\
\text { necressary to ensure compliance with } \\
\text { administrative controls to prevent } \\
\text { intrusion into contaminated soil } \\
\text { zones. }\end{array}$ & - Easily implemented. \\
\hline Cost & $\$ 0$ & $\$ 38,018$ & $\$ 295,109$ \\
\hline
\end{tabular}


Table 3-2

Comparative Evaluation of Alternatives

\begin{tabular}{|c|c|}
\hline Evaluation Criteria & Comparative Evaluation \\
\hline \multicolumn{2}{|r|}{ Closure Standards } \\
\hline $\begin{array}{l}\text { Protection of Human Health and } \\
\text { the Environment }\end{array}$ & $\begin{array}{l}\text { Alternatives } 2 \text { and } 3 \text { meet corrective action objectives; Alternative } 1 \text { does not. No worker exposure to risks is associated } \\
\text { with Alternatives } 1 \text { and } 2 \text {. Low risks are associated with Alternative 3. NAC 445A.227 (2) (a-k) analysis shows the } \\
\text { contaminants are not threatening groundwater. }\end{array}$ \\
\hline $\begin{array}{l}\text { Compliance with Media Cleanup } \\
\text { Standards }\end{array}$ & $\begin{array}{l}\text { Alternative } 1 \text { does not comply with media cleanup standards. Alternative } 2 \text { controls access to contaminants, effectively } \\
\text { eliminating exposure pathways. Alternative } 3 \text { meets media cleanup standards by removing soil containing COCs at } \\
\text { concentrations exceeding PALs and eliminating exposure pathways at the CAU. }\end{array}$ \\
\hline $\begin{array}{l}\text { Control the Source(s) of the } \\
\text { Release }\end{array}$ & The sources to CAU 490 have been discontinued. \\
\hline $\begin{array}{l}\text { Comply with Applicable Federal, } \\
\text { State, and Local Standards for } \\
\text { Waste Management }\end{array}$ & $\begin{array}{l}\text { Alternatives } 1 \text { and } 2 \text { do not generate waste. Alternative } 3 \text { will generate large volumes of waste that will be handled in } \\
\text { accordance with applicable standards. }\end{array}$ \\
\hline \multicolumn{2}{|r|}{ Remedy Selection Decision Factors } \\
\hline $\begin{array}{l}\text { Short-Term Reliability and } \\
\text { Effectiveness }\end{array}$ & No risks are associated with Alternatives 1 and 2. Risks are associated with Alternative 3. \\
\hline $\begin{array}{l}\text { Reduction of Toxicity, Mobility, } \\
\text { and/or Volume }\end{array}$ & $\begin{array}{l}\text { Alternative } 2 \text { results in a reduction of mobility of the subsurface COCs. Alternative } 3 \text { results in a reduction of all three } \\
\text { characteristics at CAU } 490 \text {. }\end{array}$ \\
\hline $\begin{array}{l}\text { Long-Term Reliability and } \\
\text { Effectiveness }\end{array}$ & $\begin{array}{l}\text { Residual risk at CAU } 490 \text { is low for Alternative } 2 \text { and nonexistent for Alternative } 3 \text {. Alternative } 2 \text { requires some } \\
\text { administrative measures to control intrusive activities. }\end{array}$ \\
\hline Feasibility & Alternatives 2 and 3 are feasible; however, Alternative 3 will be more resource intensive. \\
\hline Cost & $\begin{array}{l}\text { The cost for Alternative } 1 \text { is } \$ 0 \text {. Alternative } 2 \text { is estimated to cost } \$ 38,018 \text {. The estimated cost for Alternative } 3 \text { is } \\
\$ 295,109 \text {. }\end{array}$ \\
\hline
\end{tabular}




\subsection{Recommended Alternative}

Based on the results of the corrective action investigation discussed in Appendix A and the detailed and comparative analysis of the potential corrective action alternatives presented in this document, the preferred corrective action alternative selected for implementation at CAU 490 is Alternative 3, Clean Closure by Excavation and Disposal. Alternative 3 was chosen for the following reasons:

- Health risks are minimized by preventing public and worker access to the contaminated soil at CAU 490 by moving contaminated soil to an appropriate disposal facility.

- All waste will be managed in accordance with federal, state, and local requirements.

- It is easily implemented with standard construction equipment utilized for removal of contaminated soil. Administrative controls will not be employed at CAU 490.

- It provides a cost-effective method for achieving protection and meeting closure requirements.

The preferred corrective action alternative was evaluated on its technical merits, focusing on performance, reliability, feasibility, and safety. The alternative was judged to meet all requirements for the technical components evaluated. The alternative meets all applicable state and federal regulations for closure of the $\mathrm{CAU}$ and will eliminate future exposure pathways to the contaminated soil at CAU 490.

During corrective action implementation, this alternative may potentially present low risks to site workers. Therefore, appropriate health and safety procedures will be developed and implemented.

Based on the evaluation in this CADD, the preferred closure method for CAU 490 is Clean Closure by Excavation and Disposal. 


\subsection{References}

CFR, see Code of Federal Regulations.

Code of Federal Regulations. 1998. Title 40 CFR Parts 260 - 282, "RCRA Regulations." Washington, DC: U.S. Government Printing Office.

Code of Federal Regulations. 1999. Title 40 CFR Parts 261.24, "Toxicity Characteristic." Washington, DC: U.S. Government Printing Office.

DOE/NV, see U.S. Department of Energy, Nevada Operations Office.

EPA, see U.S. Environmental Protection Agency.

FFACO, see Federal Facility Agreement and Consent Order.

Federal Facility Agreement and Consent Order. 1996 (as amended). Agreed to by the State of Nevada, the U.S. Department of Energy, and the U.S. Department of Defense.

Moore, J., Science Applications International Corporation. 1999. Memorandum to M. Todd (SAIC) entitled, "Background Concentrations for NTS and TTR Soil Samples," 3 February. Las Vegas, NV: ITLV.

NAC, see Nevada Administrative Code.

Nevada Administrative Code. 1998a. NAC 444, "Sanitation." Carson City, NV.

Nevada Administrative Code. 1998b. NAC 445A, "Water Controls." Carson City, NV.

Nevada Administrative Code. 1998c. NAC 459, "Hazardous Materials." Carson City, NV.

NRS, see Nevada Revised Statutes.

NBMG, see Nevada Bureau of Mines and Geology.

Nevada Bureau of Mines and Geology. 1998. Mineral and Energy Resource Assessment of the Nellis Air Force Range, Open-File Report 98-1. Reno, NV.

Nevada Revised Statutes. 1995. NRS 459.400-459.600, “Disposal of Hazardous Waste." Carson City, NV.

SNL, see Sandia National Laboratories. 
Sandia National Laboratories. 1999. 1998 Annual Site Environmental Report, Tonopah Test Range, Nevada, SAND99-2279. Albuquerque, NM.

U.S. Department of Energy, Nevada Operations Office. 1994. Project Management Plan, Rev. 0. Las Vegas, NV.

U.S. Department of Energy, Nevada Operations Office. 1996a. Corrective Action Unit Work Plan, Tonopah Test Range, Nevada, Rev. 0, DOE/NV--443. Las Vegas, NV.

U.S. Department of Energy, Nevada Operations Office. 1996b. Final Environmental Impact Statement for the Nevada Test Site and Offsite Locations in the State of Nevada, DOE/EIS 0243. Las Vegas, NV.

U.S. Department of Energy, Nevada Operations Office. 1996c. Industrial Sites Quality Assurance Project Plan, Nevada Test Site, Nevada, Rev. 1, DOE/NV--372. Las Vegas, NV.

U.S. Department of Energy, Nevada Operations Office. 1998. Corrective Action Decision Document for the Area 3 Landfill Complex, Tonopah Test Range, Nevada, Corrective Action Unit 424, Rev. 0, DOE/NV--496. Las Vegas, NV.

U.S. Department of Energy, Nevada Operations Office. 1999. Closure Report for Corrective Action Unit 424: Area 3 Landfill Complex, Tonopah Test Range, Nevada, Rev. 0, DOE/NV/11718--283. Las Vegas, NV.

U.S. Department of Energy, Nevada Operations Office. 2000. Corrective Action Investigation Plan (CAIP) for Corrective Action Unit 490: Station 44 Burn Area, Tonopah Test Range, Nevada, Rev. 0, DOE/NV--613. Las Vegas, NV.

U.S. Environmental Protection Agency. 1991. Guidance on RCRA Corrective Action Decision Documents, EPA/540/G-91/011. Washington, DC: Office of Research and Development.

U.S. Environmental Protection Agency. 1994. Final RCRA Corrective Action Plan, EPA/520-R-94-004. Washington, DC: Office of Solid Waste and Emergency Response. 


\section{Appendix A}

Corrective Action Investigation Report for CAU 490: Station 44 Burn Area Tonopah Test Range, Nevada 


\section{A.1.0 Introduction}

This appendix presents the investigation activities and analytical results from the corrective action investigation conducted at CAU 490, Station 44 Burn Area at the TTR. Corrective Action Unit 490 consists of four CASs: the Fire Training Area (CAS 03-56-001-03BA) located southwest of Area 3, Station 44 Burn Area (CAS RG-56-001-RGBA) located west of Main Lake, Sandia Service Yard (CAS 03-58-001-03FN) located north of the northwest corner of Area 3, and the Gun Propellant Burn Area (CAS 09-54-001-09L2) located south of the Area 9 Compound on the TTR. The corrective action investigation was conducted in accordance with the requirements set forth in the Corrective Action Investigation Plan for Corrective Action Unit 490: Station 44 Burn Area, Tonopah Test Range, Nevada (DOE/NV, 2000), as developed under the Federal Facility Agreement and Consent Order (1996).

Historically, the FTA was used for training exercises where tires and wood were ignited with diesel fuel only. Material burning was confined to an area demarcated by a steel ring approximately $15 \mathrm{ft}$ in diameter. The Station 44 Burn Area (STA44) was used for fire training exercises and consisted of two wooden structures. Tires, wood, and the structures were ignited with diesel fuel, and water was used as the only extinguishing agent. The Sandia Service Yard (SSY) was used to store items including: wood, tires, metal, electronic and office equipment, construction debris, and drums of oil/grease. The Gun Propellant Burn Area (GPBA) was used to burn excess artillery gun propellant, solid-fuel rocket motors, black powder, and deteriorated explosives (Comp C-4).

The four CASs were investigated because process knowledge indicated that surface and subsurface soils in the vicinity of the CASs may have been impacted by releases of COPCs from various operations at the TTR. Additional information relating to the site history, planning, and scope of the investigation is presented in the CAIP (DOE/NV, 2000) and will not be repeated in this report.

\section{A.1.1 Project Objectives}

The following were the primary objectives for this project:

- Determine if COPCs are present at each CAS. 
- $\quad$ Determine if COPC concentrations exceed field-screening levels (FSLs).

- Determine if COPC concentrations exceed PALs.

- Identify the vertical and lateral extent of the COPCs.

- Determine the nature and extent of contamination with enough certainty to support selection of corrective action alternatives for each CAS.

The soil sample collection locations were based on site conditions at each CAS and the strategy devised in the DQO process, as outlined in the CAIP (DOE/NV, 2000).

\section{A.1.2 Report Content}

This report contains information and data in sufficient detail to support the selection of a preferred corrective action alternative in the CADD. The contents of this report are as follows:

- Section A.1.0 describes the investigation background, objectives, and the report content.

- Section A.2.0 provides information regarding the field activities and sampling methods.

- Section A.3.0 summarizes the results of the laboratory analyses from the investigation sampling.

- Section A.4.0 discusses the quality assurance (QA) and quality control (QC) procedures that were followed and the results of the QA and QC activities.

- Section A.5.0 is a summary of the investigation results.

- Section A.6.0 cites the references.

The complete field documentation and laboratory data, including Field Activity Daily Logs, Sample Collection Logs, Analysis Request/Chain-of-Custody Forms, soil sample descriptions, laboratory certificates of analyses, analytical results, and surveillance results are not contained in this report. These documents are retained in project files. 


\section{A.2.0 Field Investigation and Sampling Activities}

The field investigation and sampling activities were conducted between July 19 and August 17, 2000. Direct-push and excavation techniques were utilized during the investigation of CAU 490.

The investigation and sampling program was managed in accordance with the requirements set forth in the CAIP (DOE/NV, 2000). The field activities were performed in accordance with an approved Site-Specific Health and Safety Plan (IT, 2000). The samples were collected by following approved protocols and procedures for sample collection, decontamination, chain of custody, shipping, and radiation screening as indicated in the CAIP (DOE/NV, 2000) and documented using Field Activity Daily Logs and sample collection logs. Quality control samples (e.g., field blanks, equipment rinsate blanks, trip blanks, and sample duplicates) were collected as required by the Industrial Sites Quality Assurance Project Plan (QAPP) (DOE/NV, 1996b) and approved procedures. During field activities, waste minimization practices were followed according to approved procedures, including segregation of the waste by waste stream.

The following is a brief summary of the corrective action investigation activities performed at each CAS at CAU 490:

- $\quad$ Fire Training Area, CAS 03-56-001-03BA

- Excavated two linear trenches utilizing a backhoe.

- Field screened soil samples for VOCs (using a PID) and TPH (using the Hanby test kit).

- Collected surface and subsurface soil samples for laboratory analyses.

- Analyzed all environmental samples for total VOCs, total SVOCs, total RCRA metals and zinc, and TPH (diesel-range organics). Additionally, 25 percent of the samples were submitted for gamma spectrometry analysis for waste management purposes.

- $\quad$ Station 44 Burn Area, CAS RG-56-001-RGBA

- Utilized direct-push (Geoprobe $\left.{ }^{\circledR}\right)$ at four locations. 
- Field screened soil samples for VOCs (using a PID) and TPH (using the Hanby test kit).

- Collected surface and subsurface soil samples for laboratory analyses.

- Analyzed all environmental samples for total VOCs, total SVOCs, total RCRA metals and zinc, and TPH (diesel-range organics). Additionally, 25 percent of samples were submitted for gamma spectrometry analysis for waste management purposes.

- Sandia Service Yard, CAS 03-58-001-03FN

- Utilized direct-push (Geoprobe $\left.{ }^{\circledR}\right)$ at twenty-six locations.

- Field screened soil samples for VOCs (using a PID) and TPH (using the Hanby test kit).

- Collected surface and subsurface soil samples for laboratory analyses.

- Analyzed all environmental samples for total VOCs, total SVOCs, total RCRA metals, total pesticides, total PCBs, and TPH (gasoline- and diesel-range organics). Additionally, 25 percent of samples were submitted for gamma spectrometry analysis for waste management purposes.

- Gun Propellant Burn Area, CAS 09-54-001-09L2

- Excavated to sample at 24 locations utilizing a backhoe.

- Field screened soil samples for VOCs (using a PID): nitroglycerine, nitroguanidine, RDX, and nitrocellulose using an immunnoassay field test kit; and alpha/beta emitters using an Electra.

- Collected surface and subsurface soil samples for laboratory analyses. Collected soil for geotechnical analyses. (Note: The geotechnical samples were not submitted for laboratory analysis).

- Analyzed all environmental samples for total VOCs, total SVOCs, total RCRA metals, TPH (diesel-range organics), nitroglycerine, nitroguanidine, RDX, nitrocellulose, and the radionuclides plutonium and uranium.

\section{A.2.1 Site Description and Conditions}

Investigation activities for CAU 490 were conducted near Area 3 and Area 9 of the TTR. The TTR is approximately $140 \mathrm{mi}$ northwest of Las Vegas, Nevada. Initial investigation locations were based on engineering drawings, historical aerial photos, and interviews with current and former TTR 
employees. Access to the investigation sites at this CAU is restricted to authorized personnel. Weather conditions at the CAS were mostly sunny to partly cloudy and hot, and no time was lost due to adverse weather conditions. The soils investigated at these CASs were suitable for sampling, and no problems were encountered. The subsurface investigation was restricted at the FTA due to a use restriction area to the north.

\section{A.2.2 Investigation Logistics}

This section describes the sample collection and investigation activities for each CAS included in CAU 490. The investigation activities at each CAS were conducted in accordance with the CAIP (DOE/NV, 2000). Some sample locations vary slightly from those planned because of field observations or conditions encountered during the investigation. Figure 1-2 shows the general locations of the CASs in Areas 3 and 9. Actual sampling and investigation activity locations for each CAS are shown in Figures: A.2-3, A.2-4, A.2-5, and A.2-6.

\section{A.2.2.1 Utility Clearances}

Utility clearances for both overhead and underground utilities were performed by Westinghouse Government Services, formerly Westinghouse Electric Company (WEC), personnel prior to the start of intrusive activities at each CAS. The utility clearance checklists were completed by both a WEC representative and the Site Supervisor, and currently reside in project files. A Schonstedt metal detector was used extensively on conductive utilities. All identified utilities were marked on the ground surface. No underground utilities were breached during the investigation.

\section{A.2.2.2 Excavation Sampling}

Excavation sampling was used at the FTA and GPBA. Excavations are designated by "E" at the FTA, followed by the actual sampling location within the excavation "E1, E2," and so on. At the GPBA, excavation sampling locations are designated by "T3-15" where T3 is the trench (excavation), and 15 represents the number of feet horizontally from the start of the trench.

The purpose of these excavations was to collect environmental samples to submit for analyses. A backhoe and excavator was used to excavate the trenches at both locations. Field screening was 
conducted on soil buckets that were submitted for analyses. Surface and near-surface samples were collected and submitted for laboratory analyses. All spoils were staged on plastic and were backfilled to the location of removal.

\section{A.2.2.3 Direct-Push}

Direct-push (Geoprobe ${ }^{\circledR}$ ) was utilized at SSY and STA44. Direct-push holes are designated at SSY by " $\mathrm{R}$ " for random sampling location and " $\mathrm{B}$ " for biased sampling location, followed by the number of the hole (B7). At STA44, direct-push holes are designated by "S" for station followed by the number of the hole (S4) that was pushed.

The direct-push method produced continuous soil cores that were used for field observations, visual classification of soils, field screening, and sampling of the surface and near-surface soil at specified depth intervals. Surface and near-surface samples were submitted for laboratory analyses. Soil samples were collected using a 2.2-in. diameter Macrocore ${ }^{\circledR}$ sampler with polyvinyl chloride (PVC) liners. Extra soil remaining after sample collection was returned to its associated sample location.

Field-screening results were used to guide the lateral and vertical extent of the investigation in the field. Sampling intervals and sample submission frequency were based on minimum requirements established during the DQO process (DOE/NV, 2000), field-screening results, waste management needs, and the discretion of the Site Supervisor.

\section{A.2.3 Fire Training Area, CAS 03-56-001-03BA Investigation}

The investigation of the FTA consisted of excavation activities to collect environmental samples to determine the presence and extent of COPCs. Table A.3-1 in Section A.3.0 lists associated sample locations, sample numbers, sample depths collected, and analyses performed for those samples submitted to the laboratory.

As prescribed in the CAIP, the sampling locations were placed along east-west and north-south trending trenches within the fire training ring. The samples were collected for field screening from 0 to $1 \mathrm{ft}, 3$ to $4 \mathrm{ft}, 8$ to $9 \mathrm{ft}, 9$ to $10 \mathrm{ft}, 12$ to $13 \mathrm{ft}, 14$ to $15 \mathrm{ft}$, and 15 to $16 \mathrm{ft}$ bgs using excavation sampling. Field-screening results were used to select the 18 environmental soil samples that were 
collected and submitted for laboratory analyses from 5 separate locations (E1, E3, E4, E6, and E8). Samples with the highest field-screening result as well as one sample with the lowest field-screening result were selected to be submitted to the laboratory. Due to the depth of contamination, an excavator with extended reach capability was utilized at this CAS. Refer to Figure A.2-1 for sample locations. Due to the CAU 424 use restriction immediately to the north of this CAS, excavation activities were not performed in a northerly direction.

Step-out sampling was conducted at five-foot intervals using the backhoe to lengthen the trenches as field-screening levels were exceeded, and visual observations indicated the presence of contamination. Extensive hydrocarbon odors were present at some locations in the dark-brown stained soil. Hanby test kit results at E4 from 8 to $9 \mathrm{ft}$ bgs indicated the highest level of diesel fuel and fuel oil contamination at $500 \mathrm{mg} / \mathrm{kg}$. Headspace field screening indicated 132.0 parts per million (ppm) at this location.

The final east-west excavation dimensions were approximately 15-ft deep, 30-ft long, and 4-ft wide. Step-out sampling was also performed by trenching ten feet to the south of the east-west trench starting at E1. An abrupt change in staining and odor was observed at about $12 \mathrm{ft}$ bgs. Additionally, at E3 and E6 and E8, the FSLs were not exceeded at any of the sample depths, so confirmatory samples were sent to the lab for analyses from these locations to define lateral extent.

In accordance with the CAIP (DOE/NV, 2000), environmental samples were analyzed for total VOCs, total SVOCs, total RCRA metals and zinc, and TPH (diesel-range organics). Additionally, 25 percent of samples were submitted for gamma spectrometry analysis for waste management purposes. QA samples were also collected at this CAS. Geotechnical and bioassessment samples were not collected. Soil descriptions of the trenches can be found on the sample collection logs which are located in project files.

\section{A.2.4 Station 44 Burn Area, CAS RG-56-001-RGBA Investigation}

The investigation of the STA44 (which was identified as 31 DAME in the field) consisted of direct-push (Geoprobe ${ }^{\circledR}$ ) activities to collect environmental samples to determine the presence and extent of the COPCs. Table A.3-1 in Section A.3.0 lists associated sample locations, sample 


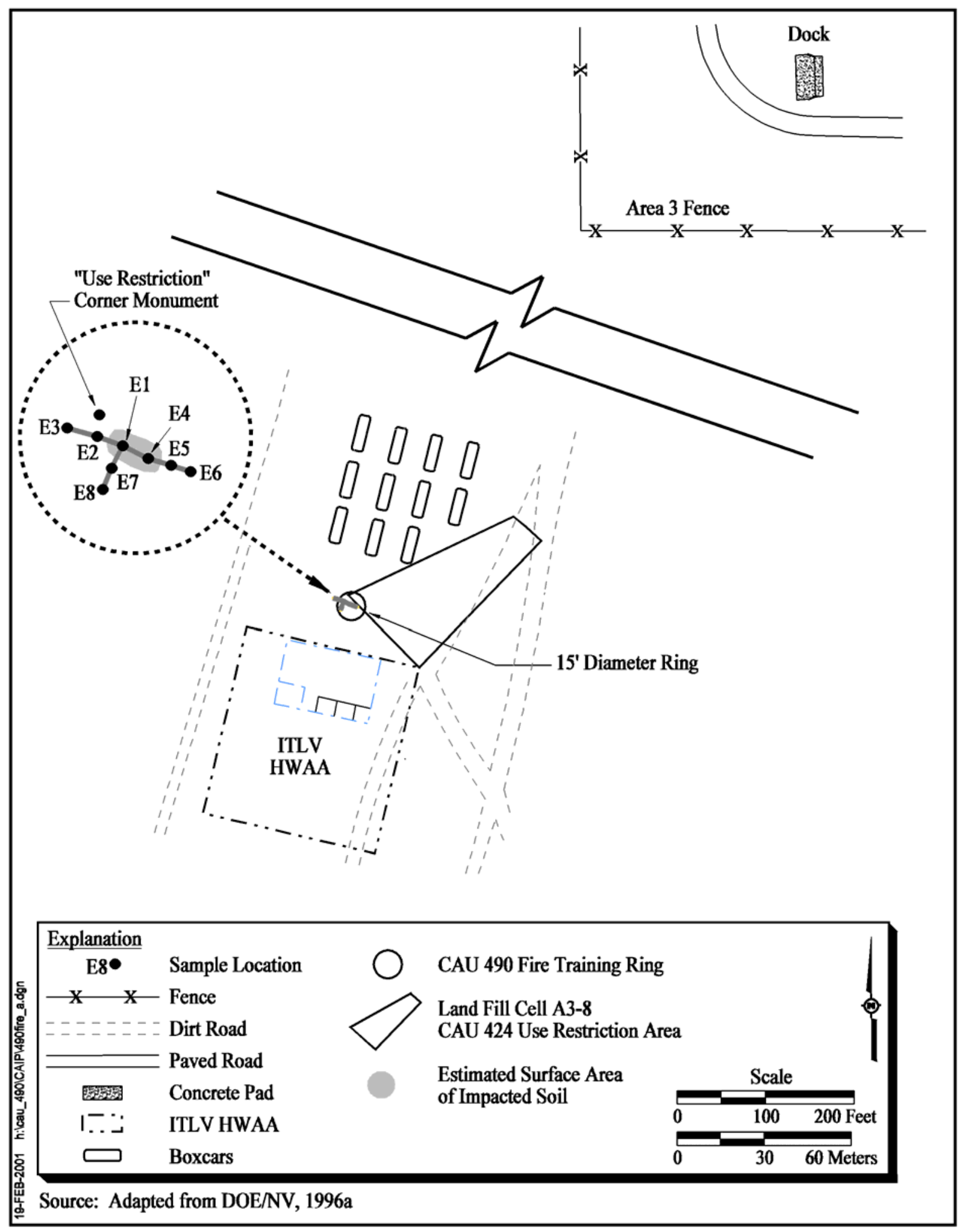

Figure A.2-1

Fire Training Area Sampling Locations, Tonopah Test Range 
numbers, sample depths collected, and analyses performed for those samples submitted to the laboratory.

Ten environmental soil samples were collected from biased surface and near-surface sample depths, and submitted for laboratory analyses from four separate locations (S1, S2, S3, and S4) using the direct-push. Refer to Figure A.2-2 for sample locations. Dark-blackish soil and pieces of burned debris (wood and floor tile) were observed at the surface of these locations. At locations S1 and S2, unexploded ordnance (UXO) was discovered to be in close proximity to sampling locations. An ordnance specialist inspected the area prior to intrusive investigation activities. The area was cleared for intrusive activities at the four known sampling locations because no evidence of live ordnance was seen at these locations.

As prescribed in the CAIP, the locations of the direct-push holes were selected within the suspected former location of the burned wooden structures. The samples were collected 0 to $1 \mathrm{ft}$ and 3 to $4 \mathrm{ft}$ bgs. Field-screening levels were not exceeded in any of the direct-push samples.

No step-out sampling was conducted as FSLs were not exceeded. No odors were present, even in the dark, stained soil. Field screening was performed using a Hanby test kit and PID. All samples were sent to the laboratory for analyses.

In accordance with the CAIP (DOE/NV, 2000), environmental samples were analyzed for total VOCs, total SVOCs, total RCRA metals and zinc, and TPH (diesel-range organics). Additionally, 25 percent of samples were submitted for gamma spectrometry analysis for waste management purposes. QA samples were also collected at this CAS. Geotechnical and bioassessment samples were not collected. Soil descriptions of the pushes can be found on the sample collections logs which are located in project files.

\section{A.2.5 Sandia Service Yard, CAS 03-58-001-03FN Investigation}

The investigation of the SSY consisted of direct-push (Geoprobe ${ }^{\circledR}$ ) activities to collect surface and near-surface environmental soil samples to determine the presence and extent of COPCs. Table A.3-1 in Section A.3.0 lists associated sample locations, sample numbers, sample depths collected, and analyses performed for those samples submitted to the laboratory. 


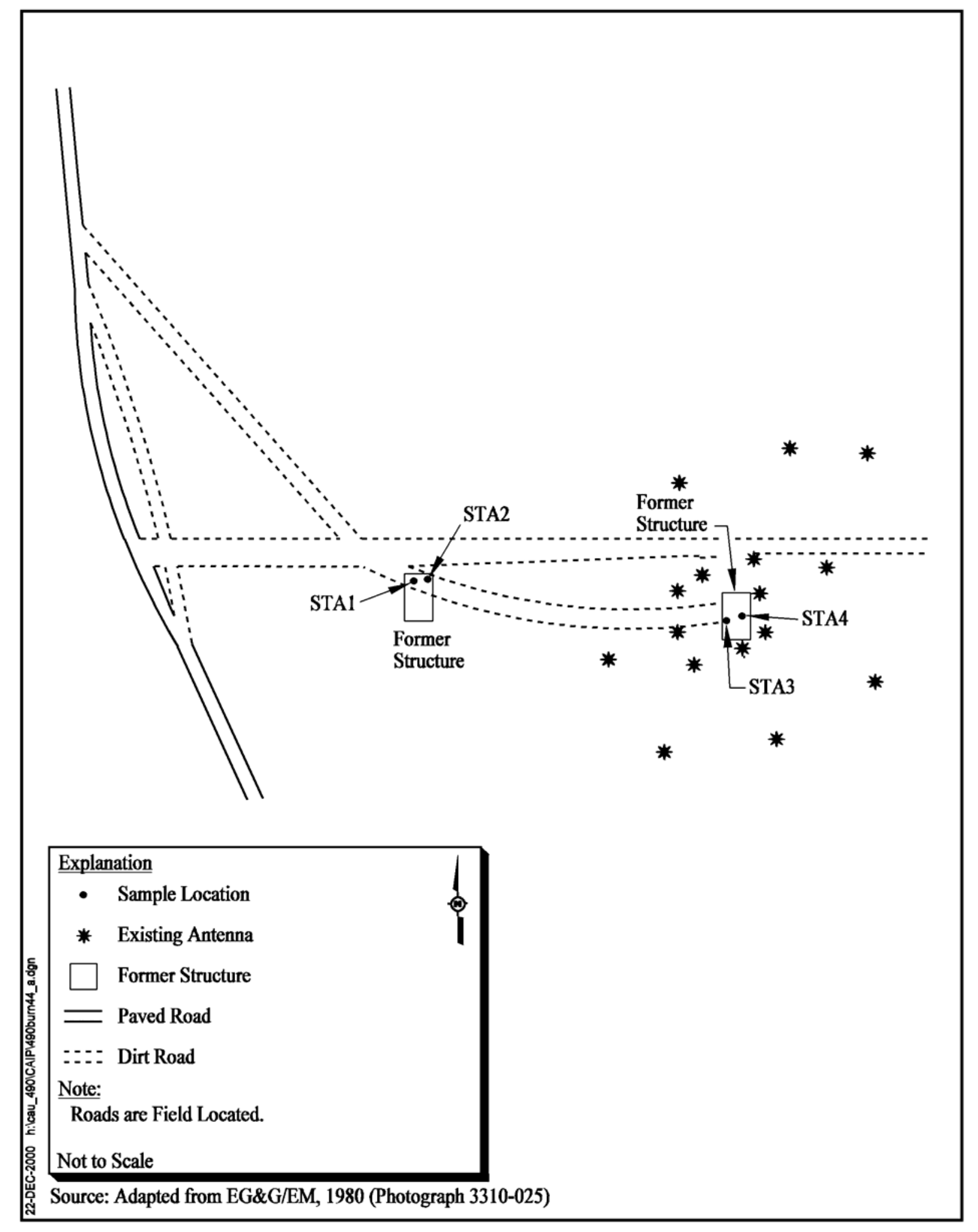

Figure A.2-2

Station 44 Burn Area Sampling Locations, Tonopah Test Range 
Fifty-five environmental soil samples were collected and submitted for laboratory analyses from 26 separate locations using direct-push sampling. As prescribed in the CAIP, the sampling locations were both biased and random. The samples were collected from 0 to $1 \mathrm{ft}$ and 3 to $4 \mathrm{ft}$ bgs. Refer to Figure A.2-3 for sample locations. Aerial photographs revealed discrepancies between site markers and historical site boundaries. Several random sampling locations were originally sited over the landfill cell A3-2 Use Restriction Area from CAU 424, located immediately to the west of SSY. As a result, the 15 random sample locations were regenerated and moved east, away from landfill cell A3-2. The eight biased sample locations were based on surface staining and aerial photographs indicating areas of possible contamination accumulation. None of the eight biased sample locations had to be moved.

Step-out sampling (5 ft from original sample locations) was conducted at three locations (B6SO, B8SO, and R12SO) as FSLs were exceeded at B6 and B8 from 0 to $1 \mathrm{ft}$ bgs for Hanby, and at R12 from 0-1 ft bgs for PID. Additionally, visual observations indicated stained soil (contamination) at B8. A slight hydrocarbon odor was observed at location B8; however, none of the other biased sample locations indicated odors present. Dark-brown soil staining was observed at other biased sample locations, and ranged from 1 to 3 in bgs; however, FSLs were not exceeded.

Hanby test kit results at B6 and B8 from 0-1 ft bgs indicated contamination at $200 \mathrm{mg} / \mathrm{kg}$; B8 showed evidence (coloration) of oil contamination. At R12, the PID measured $26.2 \mathrm{ppm}$ from 0-1 ft bgs. The presence of surface contamination did not complicate efforts to collect "clean" confirmatory samples using direct-push because the contamination was confined to the surface and the Geoprobe ${ }^{\circledR}$ was able to penetrate deep enough to acquire two consecutive clean field-screening results. Additionally, at the stepout locations B6SO, B8SO, and R12SO, the FSLs were not exceeded at any of the sample depths, and confirmatory samples were sent to the laboratory for analyses.

In accordance with the CAIP (DOE/NV, 2000), environmental samples were analyzed for total VOCs, total SVOCs, total RCRA metals, TPH (diesel-range and gasoline-range organics), PCBs, and pesticides. In additional, 25 percent of samples were submitted for gamma spectrometry analysis for waste management purposes. QA samples were also collected at this CAS. 


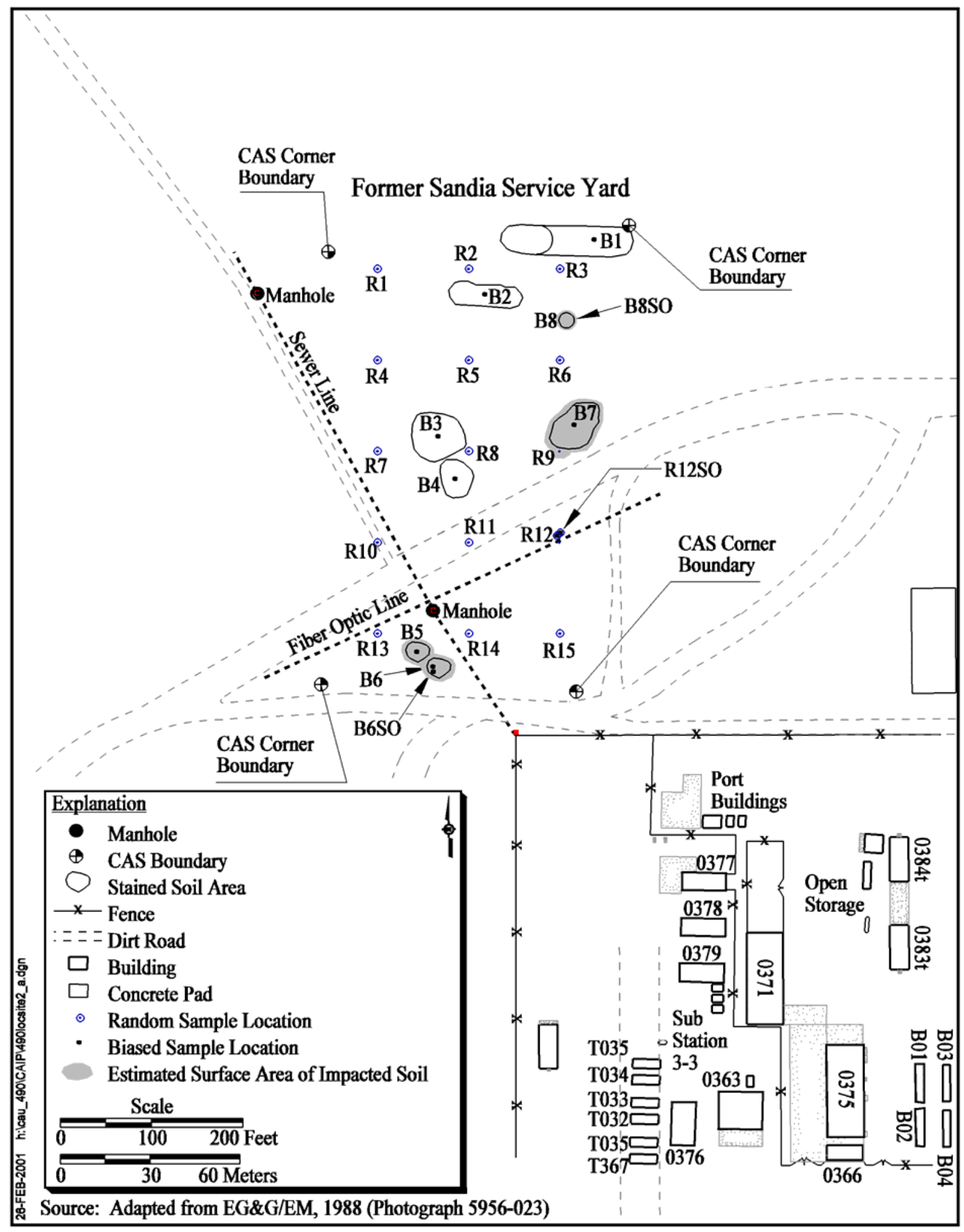

Figure A.2-3

Sandia Service Yard Sampling Locations, Tonopah Test Range 
Geotechnical and bioassessment samples were not collected. Soil descriptions of the pushes can be found on the sample collection logs which are located in project files.

\section{A.2.6 Gun Propellant Burn Area, CAS 09-54-001-09L2 Investigation}

The investigation of the GPBA consisted of excavation activities to collect surface and subsurface environmental soil samples to determine the presence and extent of COPCs. Table A.3-1 in Section A.3.0 lists associated sample locations, sample numbers, sample depths collected, and analyses performed for those samples submitted to the laboratory.

Forty-seven environmental soil samples were submitted for laboratory analyses from 26 separate locations using excavation sampling. As prescribed in the CAIP, the sampling locations were biased and the depth intervals collected were from 0 to $1 \mathrm{ft}, 3$ to $4 \mathrm{ft}, 5$ to $6 \mathrm{ft}$, and 20 to $22 \mathrm{ft}$ bgs. Figure A.2-4 shows the sample locations. The biased sample locations were chosen based on surface and subsurface visual observations, aerial photographs, and magnetic surveys.

A magnetometer survey revealed several locations to be further investigated by either hand digging or backhoe if the ground was too hard. Some of the items discovered were pieces of plastic, styrofoam, plastic silverware, soda bottles and cans, empty oil cans, an empty one-gallon kerosene can, nuts, bolts, nails, and scrap metal. This waste was transported for disposal or recycling at TTR. During the investigation, previously identified anomalies including rockets and other debris were unearthed and removed for disposal. No explosives were found either by field screening or visually. A firewire was found leading into two pits, confirming the use of the pits for burning. However, no unused or residual explosives were found at these pits.

A limited surface radiological walkover survey was conducted at GPBA. This survey revealed no radiological contamination present at the surface.

Twenty background soil samples were collected by hand from the area surrounding GPBA (Figure A.2-5). The samples were collected from the surface to a depth of $0.5 \mathrm{ft}$ and were used to establish FSLs for alpha- and beta-emitting radionuclides. The FSLs for radiation monitoring were established as the average activity of 20 background samples plus two times the standard deviation 


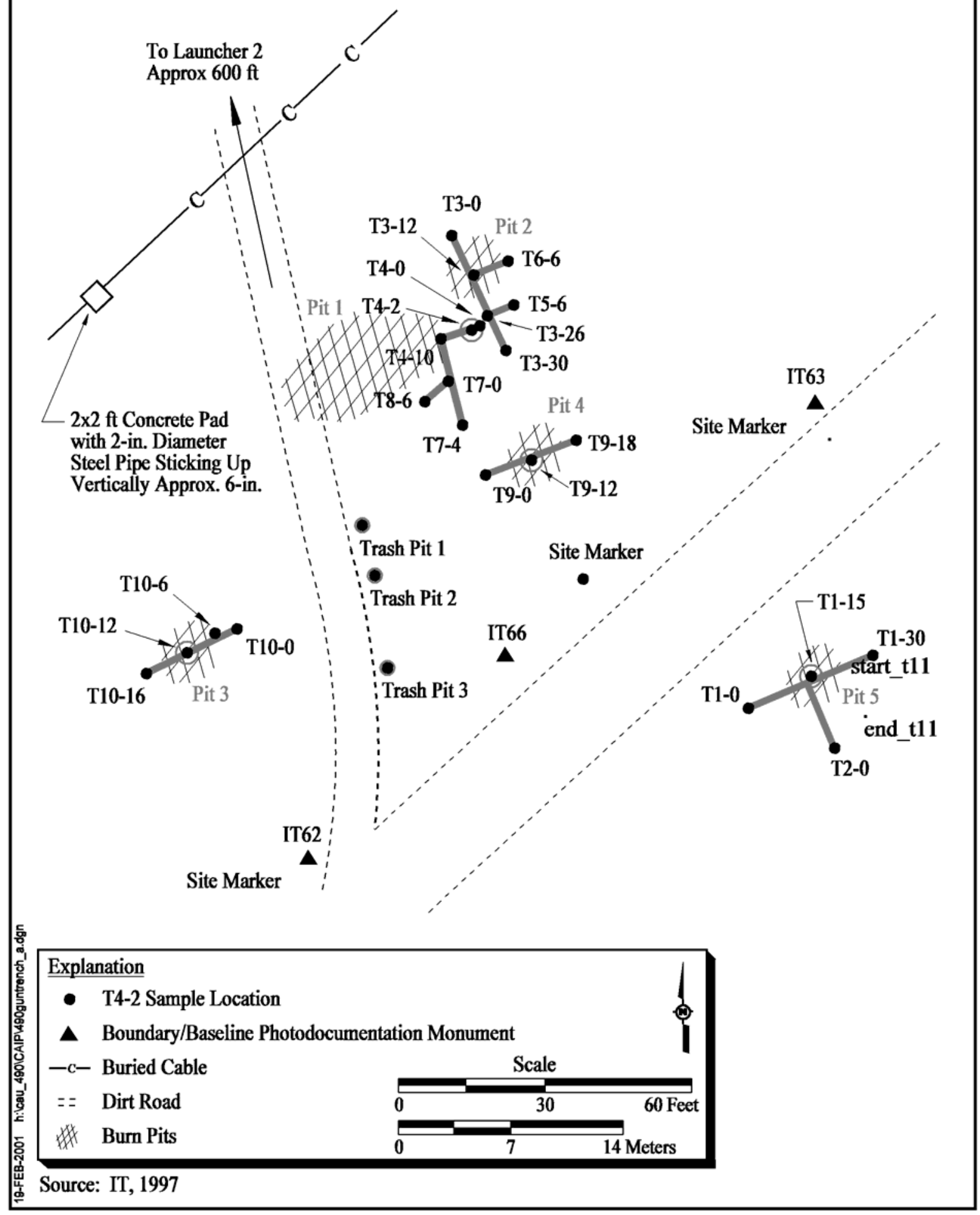

Figure A.2-4

Gun Propellant Burn Area Showing Sampling Locations, Tonopah Test Range 


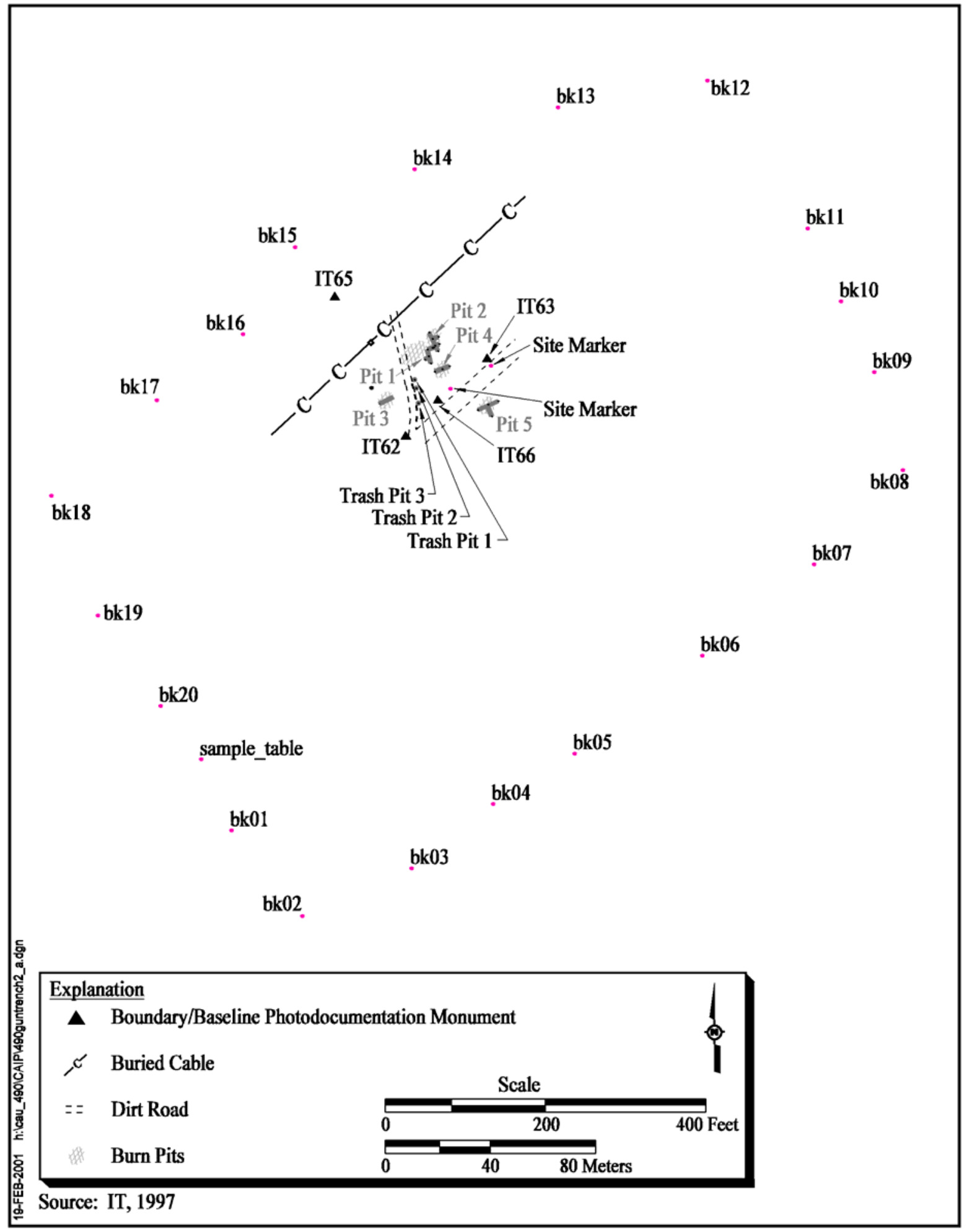

Figure A.2-5

Gun Propellant Burn Area Showing Location of Background Radiological Soils Samples, Tonopah Test Range 
of the average activity of the 20 background samples. The FSL for alpha was established at 78 disintegrations per minute $(\mathrm{dpm}) / 100$ square centimeters $\left(\mathrm{cm}^{2}\right)$ and $1,983 \mathrm{dpm} / 100 \mathrm{~cm}^{2}$ for beta.

No horizontal step-out sampling was conducted; however, FSLs were exceeded for VOCs at location T1-0 at the 3 to $4 \mathrm{ft}$ depth (42.6 ppm), and at location T10-0 at the 3-4 ft depth (36.0 ppm). Results from confirmatory samples sent to the laboratory for analysis were nondetect at both locations. Additionally, visual observations indicated no stained soil, and no odors were observed at any of the sample locations.

In accordance with the CAIP (DOE/NV, 2000), environmental samples were analyzed for total VOCs, total SVOCs, total metals, TPH (diesel-range organics), nitroaromatics and nitramines (including nitoglycerine), nitroguanidine, and nitrocellulose. Samples were also submitted for isotopic plutonium and isotopic uranium analysis. Quality Assurance samples were also collected at this CAS. A geotechnical sample was also collected; however, it was not submitted for laboratory analysis. Soil descriptions of the trench sample locations can be found on the sample collection logs which are located in project files.

\section{A.2.7 Field Screening}

All soil samples were screened for staining or odor. The sample collection logs were used to record these observations. Field-screening activities were performed as specified in the CAIP (DOE/NV, 2000). Established FSLs were used to guide sample collection both laterally and vertically and to provide a basis for the selection of additional environmental samples for laboratory analyses. The field-screening level for VOCs (established with the headspace method using a photoionization detector) at each of the CASs was $20 \mathrm{ppm}$. Field-screening levels were determined for TPH (using the Hanby test kit) at STA44, FTA, and SSY. The FSL for TPH was established at $100 \mathrm{ppm}$. Field-screening levels were determined for radiation (for alpha and beta using an Electra) at GPBA. The radiological FSL at GPBA was defined as the mean background activity level plus two times the standard deviation of 20 background sample readings. The FSL for alpha was established at $78 \mathrm{dpm} / 100 \mathrm{~cm}^{2}$ and $1,983 \mathrm{dpm} / 100 \mathrm{~cm}^{2}$ for beta. The radiological FSL was determined prior to the start of field activities at GPBA. Additionally at GPBA, field-screening levels were established for nitroglycerine, nitroguanidine, RDX, and nitrocellulose. Even though 
the field test kit detected all the required constituents (nitroglycerine, nitroguanidine, RDX, and nitrocellulose), the test kits could not differentiate between the different constituents; therefore, the constituent with the lowest FSL (RDX at $5.0 \mathrm{ppm}$ ) was used for this investigation. The Hanby test kit was not used to field screen for TPH at GPBA due to the potential to generate mixed waste.

\section{A.2.8 Sample Collection}

Samples were collected in accordance with procedures specified in the CAIP (DOE/NV, 2000). The following sequence was used in collecting soil samples at CAU 490. The CAS-specific soils were screened for VOCs, TPH (except GPBA), explosives (GPBA only), and alpha/beta-emitting radionuclides (GPBA only) prior to collection of soil samples. Total VOCs, TPH gasoline, TPH and VOC headspace screening samples were collected immediately after health and safety screening and directly from the backhoe bucket or Geoprobe ${ }^{\circledR}$ PVC sleeve. Remaining required soil sample volumes were transferred from the backhoe bucket or PVC sleeve into a clean stainless-steel bowl using clean scoops and homogenized. Samples from the GPBA were collected using nonsparking tools and were placed in appropriate containers for storage and transport. Total SVOCs and metals, TPH diesel, PCBs, total pesticides, isotopic plutonium, gamma spectrometry, and isotopic uranium samples were collected from the homogenized soil and placed in appropriate containers, temporarily labeled, and sealed with custody tape.

After samples were identified as laboratory samples, labels printed with the sample number, sample collection date/time, sampling team members, preservative, sample matrix, and requested analyses were attached to each of the containers. Each sample container was then wrapped in protective bubble wrap (if applicable), placed into a sealable bag, and stored in either an iced cooler or refrigerator with a trip blank (if applicable). Sample media collected but not submitted to the laboratory was returned to the collection site.

One geotechnical sample was collected to assess geological and hydrological parameters of the native soil at GPBA. This sample was not submitted for analyses because the geotechnical data was determined to not assist in alternative selection or site closure at this CAS. A geotechnical sample was not collected at any of the other CASs. 


\section{A.2.9 Waste Management}

Investigation-derived waste that came in contact with potentially contaminated media was segregated into the following five waste streams:

- $\quad$ Personal protective equipment (PPE) and sampling equipment

- Decontamination rinsate

- Hanby waste

- $\quad(\mathrm{RDX})$ test kit waste

- Plastic or other material (e.g., decontamination pad liner, plastic sheeting placed under trenched spoils)

Soil incidental to sample collection was placed back into the associated trench or boring.

Hazardous waste generated from Hanby and RDX test kits during site operations were labeled as such and placed in the Hazardous Waste Accumulation Area (HWAA). All other waste was managed as potentially hazardous in the HWAA. The HWAAs were located within the boundaries of each CAS investigation area. Satellite Accumulation Areas (SAAs) were established inside the HWAA to manage hazardous waste streams.

Information regarding each container of investigation-derived waste (IDW) was documented in a project-specific waste management logbook. As discussed in the CAIP (DOE/NV, 2000), IDW generated at each individual CAS was transferred to appropriate disposal facilities after sample analyses and waste class determinations had been performed. Rinsate was disposed of at a sanitary lagoon at the NTS. The solid, sanitary, and hydrocarbon waste (both PPE and plastic) were disposed of at the permitted NTS Solid Waste Management Units. Hazardous waste (Hanby and RDX test kit) was shipped from the SSA to an off-site, permitted treatment, storage, and disposal facility for treatment and disposal. Miscellaneous sanitary debris, as discussed in Section A.2.6, was disposed of or recycled at TTR. 


\section{A.2.10 Geology}

Surface soils around each CAS consist of sand, gravel, and cobbles with sparse vegetation. Fill material, when identified, typically consisted of sands and gravels. Native soil in Area 3 and Station 44 Burn Area was typically poorly-graded silty to gravelly sand. Native soil in Area 9 consists of alternating layers of poorly graded sands to silty sands. Detailed field descriptions were not performed at any of the CASs; however, the sample collection logs provide a brief description of the soil of each sample collected and are located in project files.

\section{A.2.11 Hydrology}

Depth to groundwater beneath the Area 3 compound is estimated at 360 to $394 \mathrm{ft}$ bgs. Depth to groundwater beneath Area 9 is estimated at $131 \mathrm{ft}$ bgs. The groundwater flow direction is generally to the north-northwest at Area 3 and to the southwest at Area 9 (DOE/NV, 1996a). Overall topography slopes gently to the northwest with surface drainage flowing in the same direction for most of the Area 3 CASs. Station 44 Burn Area has a gentle south to southeastward sloping gradient which may cause surface drainage to flow in that direction. The surface drainage flow at Area 9 is variable but ultimately flows to the northwest toward the dry lake bed. No saturated zones were found in the subsurface at any of the CASs. 


\section{A.3.0 Investigation Results}

The analytical results of samples collected from each CAS at CAU 490 have been compiled and evaluated to determine the presence and/or extent of contamination. The analytical results are summarized in the following subsections. The complete laboratory result data packages are retained in project files.

During direct-push and excavation activities, a total of 129 soil samples were collected and submitted for laboratory analyses. Additionally, 52 liquid samples and 1 resin sample were collected for quality control and submitted for laboratory analyses. A list of the samples collected at all four CAS and the parameters analyzed for are presented in Table A.3-1. The analytical parameters and laboratory analytical methods used for these investigations are presented in Table A.3-2. Samples collected for chemical and radiological analyses were submitted to Paragon Analytical Services, in Fort Collins, Colorado, for laboratory analysis.

The analytical parameters were selected through the application of site process knowledge according to the Guidance for the Data Quality Objectives Process (EPA, 2000) and agreed upon during the DQO meeting. Preliminary action levels for off-site laboratory analytical methods were determined during the DQO process and are based on NDEP Corrective Action Regulations (NAC, 1997) and the EPA is PRGs (EPA, 1998) for chemical parameters under the industrial scenario. The PALs for laboratory radiological methods are isotope-specific and are defined as the maximum activity for that isotope found in previously analyzed environmental samples taken from undisturbed background locations from Area 3 and Area 9 at TTR, as well as the NTS. The results of the DQO process are documented in the CAIP (DOE/NV, 2000) with the remainder of the documentation retained in the project files. Sampling activities were designed to detect contaminants of potential concern and conducted to either confirm or disprove the assumptions made in the DQO process.

\section{A.3.1 Total Volatile Organic Compounds}

All total VOC analytical results for soil samples collected at FTA and Sta44 were below minimum reporting limits as established in the CAIP (DOE/NV, 2000). The total VOC analytical results for 
Table A.3-1

CAU 490, Station 44 Burn Area, Tonopah Test Range Sampling Locations and Analyses

(Page 1 of 7 )

\begin{tabular}{|c|c|c|c|c|c|c|}
\hline Location & $\begin{array}{l}\text { Sample } \\
\text { Number }\end{array}$ & $\begin{array}{c}\text { Date } \\
\text { Collected }\end{array}$ & $\begin{array}{c}\text { Depth } \\
\text { (feet bgs) }\end{array}$ & $\begin{array}{l}\text { Sample } \\
\text { Matrix }\end{array}$ & Sample Type & Analyses \\
\hline \multicolumn{7}{|c|}{ Fire Training Area (FTA) } \\
\hline E1 & FTA00101 & $7 / 27 / 2000$ & $0-1$ & Soil & Environmental & $1,2,3,4$ \\
\hline $\mathrm{E} 1$ & FTA00102 & $7 / 27 / 2000$ & $3-4$ & Soil & Environmental & $1,2,3,4$ \\
\hline E1 & FTA00103 & $7 / 27 / 2000$ & $9-10$ & Soil & $\begin{array}{c}\text { Environmental \& } \\
\text { MS/MSD }\end{array}$ & $1,2,3,4,10$ \\
\hline E1 & FTA00104 & $7 / 27 / 2000$ & $14-15$ & Soil & Environmental & $1,2,3,4$ \\
\hline E3 & FTA00105 & $7 / 27 / 2000$ & $0-1$ & Soil & Environmental & $1,2,3,4$ \\
\hline E3 & FTA00106 & $7 / 27 / 2000$ & $3-4$ & Soil & Environmental & $1,2,3,4$ \\
\hline E3 & FTA00107 & $7 / 27 / 2000$ & $8-9$ & Soil & Environmental & $1,2,3,4$ \\
\hline E3 & FTA00108 & $7 / 27 / 2000$ & $14-15$ & Soil & Environmental & $1,2,3,4$ \\
\hline E6 & FTA00109 & $7 / 27 / 2000$ & $0-1$ & Soil & Environmental & $1,2,3,4,10$ \\
\hline E6 & FTA00110 & $7 / 27 / 2000$ & $3-4$ & Soil & Environmental & $1,2,3,4$ \\
\hline E6 & FTA00111 & $7 / 27 / 2000$ & $8-9$ & Soil & Environmental & $1,2,3,4$ \\
\hline E6 & FTA00112 & $7 / 27 / 2000$ & $14-15$ & Soil & Environmental & $1,2,3,4$ \\
\hline E8 & FTA00113 & $8 / 1 / 2000$ & $0-1$ & Soil & Environmental & $1,2,3,4,10$ \\
\hline E8 & FTA00114 & $8 / 1 / 2000$ & $8-9$ & Soil & Environmental & $1,2,3,4$ \\
\hline E8 & FTA00115 & $8 / 1 / 2000$ & $8-9$ & Soil & FD of FTA00114 & $1,2,3,4$ \\
\hline $\mathrm{E} 4$ & FTA00116 & $8 / 17 / 2000$ & $8-9$ & Soil & Environmental & $1,2,3,4$ \\
\hline E4 & FTA00117 & $8 / 17 / 2000$ & $12-13$ & Soil & Environmental & $1,2,3,4$ \\
\hline E4 & FTA00118 & $8 / 17 / 2000$ & $15-16$ & Soil & Environmental & $1,2,3,4$ \\
\hline \multicolumn{7}{|c|}{ Gun Propellant Burn Area (GPBA) ${ }^{a}$} \\
\hline $\mathrm{T} 1-0$ & GPB00101 & $7 / 31 / 2000$ & $0-1$ & Soil & Environmental & $1,2,3,4,8,9,11,12,13$ \\
\hline T1-0 & GPB00102 & $7 / 31 / 2000$ & $3-4$ & Soil & Environmental & $1,2,3,4,8,9,11,12,13$ \\
\hline $\mathrm{T} 1-15$ & GPB00103 & $8 / 2 / 2000$ & $0-1$ & Soil & Environmental & $1,2,3,4,8,9,11,12,13$ \\
\hline $\mathrm{T} 1-15$ & GPB00104 & $8 / 2 / 2000$ & $3-4$ & Soil & Environmental & $1,2,3,4,8,9,11,12,13$ \\
\hline $\mathrm{T} 1-30$ & GPB00105 & $8 / 2 / 2000$ & $0-1$ & Soil & Environmental & $1,2,3,4,8,9,11,12,13$ \\
\hline $\mathrm{T} 1-30$ & GPB00106 & $8 / 2 / 2000$ & $3-4$ & Soil & Environmental & $1,2,3,4,8,9,11,12,13$ \\
\hline T2-0 & GPB00107 & $8 / 2 / 2000$ & $0-1$ & Soil & Environmental & $1,2,3,4,8,9,11,12,13$ \\
\hline T2-0 & GPB00108 & $8 / 2 / 2000$ & $3-4$ & Soil & Environmental & $1,2,3,4,8,9,11,12,13$ \\
\hline
\end{tabular}


Table A.3-1

CAU 490, Station 44 Burn Area, Tonopah Test Range Sampling Locations and Analyses

(Page 2 of 7 )

\begin{tabular}{|c|c|c|c|c|c|c|}
\hline Location & $\begin{array}{l}\text { Sample } \\
\text { Number }\end{array}$ & $\begin{array}{c}\text { Date } \\
\text { Collected }\end{array}$ & $\begin{array}{c}\text { Depth } \\
\text { (feet bgs) }\end{array}$ & $\begin{array}{l}\text { Sample } \\
\text { Matrix }\end{array}$ & Sample Type & Analyses \\
\hline T3-0 & GPB00109 & $8 / 8 / 2000$ & $0-1$ & Soil & Environmental & $1,2,3,4,8,9,11,12,13$ \\
\hline T3-0 & GPB00110 & $8 / 8 / 2000$ & $3-4$ & Soil & Environmental & $1,2,3,4,11,12,13$ \\
\hline T3-12 & GPB00111 & $8 / 9 / 2000$ & $0-1$ & Soil & Environmental & $1,2,3,4,8,9,11,12,13$ \\
\hline T3-26 & GPB00112 & $8 / 9 / 2000$ & $0-1$ & Soil & Environmental & $1,2,3,4,8,9,11,12,13$ \\
\hline T3-26 & GPB00113 & $8 / 9 / 2000$ & $3-4$ & Soil & Environmental & $1,2,3,4,8,9,11,12,13$ \\
\hline T3-30 & GPB00114 & $8 / 9 / 2000$ & $0-1$ & Soil & Environmental & $1,2,3,4,8,9,11,12,13$ \\
\hline T3-30 & GPB00115 & $8 / 9 / 2000$ & $3-4$ & Soil & Environmental & $1,2,3,4,8,9,11,12,13$ \\
\hline $\mathrm{T} 4-0$ & GPB00116 & $8 / 9 / 2000$ & $0-1$ & Soil & Environmental & $1,2,3,4,8,9,11,12,13$ \\
\hline $\mathrm{T} 4-0$ & GPB00117 & $8 / 9 / 2000$ & $3-4$ & Soil & Environmental & $1,2,3,4,8,9,11,12,13$ \\
\hline $\mathrm{T} 4-2$ & GPB00118 & $8 / 10 / 2000$ & $20-22$ & Soil & Environmental & $1,2,3,4,8,9,11,12,13$ \\
\hline $\mathrm{T} 4-2$ & GPB00119 & $8 / 10 / 2000$ & $20-22$ & Soil & FD of GPB00118 & $1,2,3,4,8,9,11,12,13$ \\
\hline $\mathrm{T} 4-10$ & GPB00120 & $8 / 10 / 2000$ & $0-1$ & Soil & $\begin{array}{c}\text { Environmental \& } \\
\text { MS/MSD }\end{array}$ & $1,2,3,4,8,9,11,12,13$ \\
\hline $\mathrm{T} 4-10$ & GPB00121 & $8 / 10 / 2000$ & $3-4$ & Soil & Environmental & $1,2,3,4,8,9,11,12,13$ \\
\hline T5-6 & GPB00122 & $8 / 10 / 2000$ & $0-1$ & Soil & Environmental & $1,2,3,4,8,9,11,12,13$ \\
\hline T5-6 & GPB00123 & $8 / 10 / 2000$ & $3-4$ & Soil & Environmental & $1,2,3,4,8,9,11,12,13$ \\
\hline Pit Rocket & GPB00124 & $8 / 10 / 2000$ & NA & Resin & Environmental & $1,2,3,4,8,9,11,12,13,15$ \\
\hline T6-6 & GPB00125 & $8 / 10 / 2000$ & $0-1$ & Soil & Environmental & $1,2,3,4,8,9,11,12,13$ \\
\hline T6-6 & GPB00126 & $8 / 10 / 2000$ & $3-4$ & Soil & Environmental & $1,2,3,4,8,9,11,12,13$ \\
\hline T7-0 & GPB00127 & $8 / 10 / 2000$ & $0-1$ & Soil & Environmental & $1,2,3,4,8,9,11,12,13$ \\
\hline T7-0 & GPB00128 & $8 / 10 / 2000$ & $5-6$ & Soil & Environmental & $1,2,3,4,8,9,11,12,13$ \\
\hline T7-4 & GPB00129 & $8 / 10 / 2000$ & $0-1$ & Soil & Environmental & $1,2,3,4,8,9,11,12,13$ \\
\hline$T 7-4$ & GPB00130 & $8 / 10 / 2000$ & $3-4$ & Soil & Environmental & $1,2,3,4,8,9,11,12,13$ \\
\hline T8-6 & GPB00131 & $8 / 10 / 2000$ & $0-1$ & Soil & Environmental & $1,2,3,4,8,9,11,12,13$ \\
\hline T8-6 & GPB00132 & $8 / 10 / 2000$ & $3-4$ & Soil & Environmental & $1,2,3,4,8,9,11,12,13$ \\
\hline T9-0 & GPB00133 & $8 / 15 / 2000$ & $0-1$ & Soil & Environmental & $1,2,3,4,8,9,11,12,13$ \\
\hline T9-0 & GPB00134 & $8 / 15 / 2000$ & $3-4$ & Soil & Environmental & $1,2,3,4,8,9,11,12,13$ \\
\hline T9-12 & GPB00135 & $8 / 15 / 2000$ & $0-1$ & Soil & Environmental & $1,2,3,4,8,9,11,12,13$ \\
\hline T9-12 & GPB00136 & $8 / 15 / 2000$ & $3-4$ & Soil & Environmental & $1,2,3,4,8,9,11,12,13$ \\
\hline
\end{tabular}


Table A.3-1

CAU 490, Station 44 Burn Area, Tonopah Test Range Sampling Locations and Analyses

(Page 3 of 7 )

\begin{tabular}{|c|c|c|c|c|c|c|}
\hline Location & $\begin{array}{l}\text { Sample } \\
\text { Number }\end{array}$ & $\begin{array}{c}\text { Date } \\
\text { Collected }\end{array}$ & $\begin{array}{c}\text { Depth } \\
\text { (feet bgs) }\end{array}$ & $\begin{array}{c}\text { Sample } \\
\text { Matrix }\end{array}$ & Sample Type & Analyses \\
\hline T9-18 & GPB00137 & $8 / 15 / 2000$ & $0-1$ & Soil & Environmental & $1,2,3,4,8,9,11,12,13$ \\
\hline T9-18 & GPB00138 & $8 / 15 / 2000$ & $3-4$ & Soil & Environmental & $1,2,3,4,8,9,11,12,13$ \\
\hline $\mathrm{T} 10-0$ & GPB00139 & $8 / 15 / 2000$ & $0-1$ & Soil & Environmental & $1,2,3,4,8,9,11,12,13$ \\
\hline $\mathrm{T} 10-0$ & GPB00140 & $8 / 15 / 2000$ & $0-1$ & Soil & FD of GPB00139 & $1,2,3,4,8,9,11,12,13$ \\
\hline $\mathrm{T} 10-0$ & GPB00141 & $8 / 15 / 2000$ & $3-4$ & Soil & $\begin{array}{c}\text { Environmental \& } \\
\text { MS/MSD }\end{array}$ & $1,2,3,4,8,9,11,12,13$ \\
\hline $\mathrm{T} 10-12$ & GPB00142 & $8 / 15 / 2000$ & $0-1$ & Soil & Environmental & $1,2,3,4,8,9,11,12,13$ \\
\hline T10-12 & GPB00143 & $8 / 15 / 2000$ & $3-4$ & Soil & Environmental & $1,2,3,4,8,9,11,12,13$ \\
\hline T10-16 & GPB00144 & $8 / 15 / 2000$ & $0-1$ & Soil & Environmental & $1,2,3,4,8,9,11,12,13$ \\
\hline $\mathrm{T} 10-16$ & GPB00145 & $8 / 15 / 2000$ & $3-4$ & Soil & Environmental & $1,2,3,4,8,9,11,12,13$ \\
\hline T10-6 & GPB00146 & $8 / 15 / 2000$ & $3-4$ & Soil & Environmental & $1,2,3,4,8,9,11,12,13$ \\
\hline T10-6 & GPB00147 & $8 / 15 / 2000$ & $5-6$ & Soil & Environmental & $1,2,3,4,8,9,11,12,13$ \\
\hline \multicolumn{7}{|c|}{ Sandia Service Yard (SSY) } \\
\hline B1 & SSY00101 & $7 / 19 / 2000$ & $0-1$ & Soil & Environmental & $1,2,3,4,6,7,10,14$ \\
\hline $\mathrm{B} 1$ & SSY00101A & $7 / 19 / 2000$ & $3-4$ & Soil & Environmental & $1,2,3,4,6,7,10,14$ \\
\hline B2 & SSY00102 & $7 / 19 / 2000$ & $0-1$ & Soil & Environmental & $1,2,3,4,6,7,10,14$ \\
\hline B2 & SSY00102A & $7 / 19 / 2000$ & $3-4$ & Soil & Environmental & $1,2,3,4,6,7,10,14$ \\
\hline B3 & SSY00103 & $7 / 19 / 2000$ & $0-1$ & Soil & Environmental & $1,2,3,4,6,7,10,14$ \\
\hline B3 & SSY00103A & $7 / 19 / 2000$ & $3-4$ & Soil & Environmental & $1,2,3,4,6,7,10,14$ \\
\hline B4 & SSY00104 & $7 / 19 / 2000$ & $0-1$ & Soil & Environmental & $1,2,3,4,6,7,10,14$ \\
\hline B4 & SSY00104A & $7 / 19 / 2000$ & $3-4$ & Soil & Environmental & $1,2,3,4,6,7,10,14$ \\
\hline B5 & SSY00105 & $7 / 19 / 2000$ & $0-1$ & Soil & Environmental & $1,2,3,4,6,7,10,14$ \\
\hline B5 & SSY00105A & $7 / 19 / 2000$ & $3-4$ & Soil & Environmental & $1,2,3,4,6,7,10,14$ \\
\hline B6 & SSY00106 & $7 / 19 / 2000$ & $0-1$ & Soil & Environmental & $1,2,3,4,6,7,14$ \\
\hline B6 & SSY00106A & $7 / 19 / 2000$ & $3-4$ & Soil & Environmental & $1,2,3,4,6,7,14$ \\
\hline B7 & SSY00107 & $7 / 20 / 2000$ & $0-1$ & Soil & Environmental & $1,2,3,4,6,7,14$ \\
\hline B7 & SSY00107A & $7 / 20 / 2000$ & $3-4$ & Soil & Environmental & $1,2,3,4,6,7,14$ \\
\hline B8 & SSY00108 & $7 / 20 / 2000$ & $0-1$ & Soil & Environmental & $1,2,3,4,6,7,14$ \\
\hline B8 & SSY00108A & $7 / 20 / 2000$ & $3-4$ & Soil & Environmental & $1,2,3,4,6,7,14$ \\
\hline
\end{tabular}


Table A.3-1

CAU 490, Station 44 Burn Area, Tonopah Test Range Sampling Locations and Analyses

(Page 4 of 7 )

\begin{tabular}{|c|c|c|c|c|c|c|}
\hline Location & $\begin{array}{l}\text { Sample } \\
\text { Number }\end{array}$ & $\begin{array}{c}\text { Date } \\
\text { Collected }\end{array}$ & $\begin{array}{c}\text { Depth } \\
\text { (feet bgs) }\end{array}$ & $\begin{array}{l}\text { Sample } \\
\text { Matrix }\end{array}$ & Sample Type & Analyses \\
\hline $\mathrm{R} 1$ & SSY00109 & $7 / 24 / 2000$ & $0-1$ & Soil & Environmental & $1,2,3,4,6,7,14$ \\
\hline $\mathrm{R} 1$ & SSY00109A & $7 / 24 / 2000$ & $3-4$ & Soil & Environmental & $1,2,3,4,6,7,14$ \\
\hline $\mathrm{R} 2$ & SSY00110 & $7 / 24 / 2000$ & $0-1$ & Soil & $\begin{array}{c}\text { Environmental \& } \\
\text { MS/MSD }\end{array}$ & $1,2,3,4,6,7,14$ \\
\hline $\mathrm{R} 2$ & SSY00110A & $7 / 24 / 2000$ & $3-4$ & Soil & Environmental & $1,2,3,4,6,7,10,14$ \\
\hline $\mathrm{R} 2$ & SSY00110B & $7 / 24 / 2000$ & $3-4$ & Soil & FD of SSY00110A & $1,2,3,4,6,7,10,14$ \\
\hline R3 & SSY00111 & $7 / 24 / 2000$ & $0-1$ & Soil & Environmental & $1,2,3,4,6,7,14$ \\
\hline R3 & SSY00111A & $7 / 24 / 2000$ & $3-4$ & Soil & Environmental & $1,2,3,4,6,7,14$ \\
\hline $\mathrm{R} 4$ & SSY00112 & $7 / 24 / 2000$ & $0-1$ & Soil & Environmental & $1,2,3,4,6,7,14$ \\
\hline $\mathrm{R} 4$ & SSY00112A & $7 / 24 / 2000$ & $3-4$ & Soil & Environmental & $1,2,3,4,6,7,14$ \\
\hline $\mathrm{R} 5$ & SSY00113 & $7 / 24 / 2000$ & $0-1$ & Soil & Environmental & $1,2,3,4,6,7,14$ \\
\hline $\mathrm{R} 5$ & SSY00113A & $7 / 24 / 2000$ & $3-4$ & Soil & Environmental & $1,2,3,4,6,7,14$ \\
\hline $\mathrm{R} 6$ & SSY00114 & $7 / 24 / 2000$ & $0-1$ & Soil & Environmental & $1,2,3,4,6,7,14$ \\
\hline $\mathrm{R} 6$ & SSY00114A & $7 / 24 / 2000$ & $3-4$ & Soil & Environmental & $1,2,3,4,6,7,14$ \\
\hline $\mathrm{R} 7$ & SSY00115 & $7 / 24 / 2000$ & $0-1$ & Soil & Environmental & $1,2,3,4,6,7,14$ \\
\hline $\mathrm{R} 7$ & SSY00115A & $7 / 24 / 2000$ & $3-4$ & Soil & Environmental & $1,2,3,4,6,7,14$ \\
\hline $\mathrm{R} 8$ & SSY00116 & $7 / 25 / 2000$ & $0-1$ & Soil & Environmental & $1,2,3,4,6,7,14$ \\
\hline $\mathrm{R} 8$ & SSY00116A & $7 / 25 / 2000$ & $3-4$ & Soil & Environmental & $1,2,3,4,6,7,14$ \\
\hline $\mathrm{R} 9$ & SSY00117 & $7 / 25 / 2000$ & $0-1$ & Soil & Environmental & $1,2,3,4,6,7,14$ \\
\hline $\mathrm{R} 9$ & SSY00117A & $7 / 25 / 2000$ & $3-4$ & Soil & Environmental & $1,2,3,4,6,7,14$ \\
\hline $\mathrm{R} 10$ & SSY00118 & $7 / 25 / 2000$ & $0-1$ & Soil & Environmental & $1,2,3,4,6,7,14$ \\
\hline $\mathrm{R} 10$ & SSY00118A & $7 / 25 / 2000$ & $3-4$ & Soil & Environmental & $1,2,3,4,6,7,14$ \\
\hline R11 & SSY00119 & $7 / 25 / 2000$ & $0-1$ & Soil & Environmental & $1,2,3,4,6,7,14$ \\
\hline R11 & SSY00119A & $7 / 26 / 2000$ & $3-4$ & Soil & Environmental & $1,2,3,4,6,7,14$ \\
\hline $\mathrm{R} 12$ & SSY00120 & $7 / 25 / 2000$ & $0-1$ & Soil & $\begin{array}{c}\text { Environmental \& } \\
\text { MS/MSD }\end{array}$ & $1,2,3,4,6,7,10,14$ \\
\hline $\mathrm{R} 12$ & SSY00120A & $7 / 25 / 2000$ & $3-4$ & Soil & Environmental & $1,2,3,4,6,7,10,14$ \\
\hline $\mathrm{R} 12$ & SSY00120B & $7 / 25 / 2000$ & $3-4$ & Soil & FD of SSY00120 & $1,2,3,4,6,10,7,14$ \\
\hline $\mathrm{R} 13$ & SSY00121 & $7 / 25 / 2000$ & $0-1$ & Soil & Environmental & $1,2,3,4,6,7,14$ \\
\hline $\mathrm{R} 13$ & SSY00121A & $7 / 25 / 2000$ & $3-4$ & Soil & Environmental & $1,2,3,4,6,7,14$ \\
\hline
\end{tabular}


Table A.3-1

CAU 490, Station 44 Burn Area, Tonopah Test Range Sampling Locations and Analyses

(Page 5 of 7 )

\begin{tabular}{|c|c|c|c|c|c|c|}
\hline Location & $\begin{array}{l}\text { Sample } \\
\text { Number }\end{array}$ & $\begin{array}{c}\text { Date } \\
\text { Collected }\end{array}$ & $\begin{array}{c}\text { Depth } \\
\text { (feet bgs) }\end{array}$ & $\begin{array}{l}\text { Sample } \\
\text { Matrix }\end{array}$ & Sample Type & Analyses \\
\hline $\mathrm{R} 14$ & SSY00122 & $7 / 25 / 2000$ & $0-1$ & Soil & Environmental & $1,2,3,4,6,7,14$ \\
\hline $\mathrm{R} 14$ & SSY00122A & $7 / 25 / 2000$ & $3-4$ & Soil & Environmental & $1,2,3,4,6,7,14$ \\
\hline R15 & SSY00123 & $7 / 25 / 2000$ & $0-1$ & Soil & Environmental & $1,2,3,4,6,7,14$ \\
\hline $\mathrm{R} 15$ & SSY00123A & $7 / 25 / 2000$ & $3-4$ & Soil & Environmental & $1,2,3,4,6,7,14$ \\
\hline B6SO & SSY00124 & $7 / 25 / 2000$ & $0-1$ & Soil & Environmental & $1,2,3,4,6,7,14$ \\
\hline B6so & SSY00124A & $7 / 25 / 2000$ & $3-4$ & Soil & Environmental & $1,2,3,4,6,7,14$ \\
\hline R12SO & SSY00125 & $7 / 26 / 2000$ & $0-1$ & Soil & Environmental & $1,2,3,4,6,7,14$ \\
\hline R12SO & SSY00125A & $7 / 26 / 2000$ & $3-4$ & Soil & Environmental & $1,2,3,4,6,7,14$ \\
\hline B8SO & SSY00126 & $7 / 26 / 2000$ & $0-1$ & Soil & $\begin{array}{c}\text { Environmental \& } \\
\text { MS/MSD }\end{array}$ & $1,2,3,4,6,7,10,14$ \\
\hline B8SO & SSY00126A & $7 / 26 / 2000$ & $3-4$ & Soil & Environmental & $1,2,3,4,6,7,10,14$ \\
\hline B8SO & SSY00126B & $7 / 26 / 2000$ & $3-4$ & Soil & FD of SSY00126A & $1,2,3,4,6,7,10,14$ \\
\hline \multicolumn{7}{|c|}{ Station 44 Burn Area (ST44) } \\
\hline STA1 & ST44SB001 & $7 / 17 / 2000$ & $0-1$ & Soil & Environmental & $1,2,3,4,10$ \\
\hline STA1 & ST44SB002 & $7 / 17 / 2000$ & $3-4$ & Soil & Environmental & $1,2,3,4,10$ \\
\hline STA 2 & ST44SB003 & $7 / 17 / 2000$ & $0-1$ & Soil & Environmental & $1,2,3,4,10$ \\
\hline STA2 & ST44SB004 & $7 / 17 / 2000$ & $3-4$ & Soil & Environmental & $1,2,3,4,10$ \\
\hline STA3 & ST44SB005 & $7 / 18 / 2000$ & $0-1$ & Soil & Environmental & $1,2,3,4,10$ \\
\hline STA3 & ST44SB006 & $7 / 18 / 2000$ & $3-4$ & Soil & Environmental & $1,2,3,4,10$ \\
\hline STA4 & ST44SB007 & $7 / 18 / 2000$ & $0-1$ & Soil & Environmental & $1,2,3,4,10$ \\
\hline STA4 & ST44SB008 & $7 / 18 / 2000$ & $3-4$ & Soil & Environmental & $1,2,3,4,10$ \\
\hline STA4 & ST44SB009 & $7 / 18 / 2000$ & $0-1$ & Soil & FD of ST44SB007 & $1,2,3,4,10$ \\
\hline STA4 & ST44SB010 & $7 / 18 / 2000$ & $3-4$ & Soil & FD of ST44SB008 & $1,2,3,4,10$ \\
\hline \multicolumn{7}{|c|}{ Quality Control Water Samples } \\
\hline FTA & FTA00200 & $7 / 27 / 2000$ & NA & Water & Trip Blank & 1 \\
\hline FTA & FTA00201 & $7 / 27 / 2000$ & NA & Water & Field Blank & $1,2,3,4,10$ \\
\hline $\begin{array}{l}\text { FTA-Deconed } \\
\text { Backhoe }\end{array}$ & FTA00202 & $7 / 27 / 2000$ & NA & Water & $\begin{array}{c}\text { Equipment } \\
\text { Rinsate Blank }\end{array}$ & $1,2,3,4,10$ \\
\hline * & FTA00203 & $7 / 27 / 2000$ & NA & Water & Trip Blank & 1 \\
\hline * & FTA00001 & $7 / 27 / 2000$ & NA & Water & Trip Blank & 1 \\
\hline
\end{tabular}


Table A.3-1

CAU 490, Station 44 Burn Area, Tonopah Test Range
Sampling Locations and Analyses

(Page 6 of 7)

\begin{tabular}{|c|c|c|c|c|c|c|}
\hline Location & $\begin{array}{l}\text { Sample } \\
\text { Number }\end{array}$ & $\begin{array}{c}\text { Date } \\
\text { Collected }\end{array}$ & $\begin{array}{c}\text { Depth } \\
\text { (feet bgs) }\end{array}$ & $\begin{array}{l}\text { Sample } \\
\text { Matrix }\end{array}$ & Sample Type & Analyses \\
\hline * & FTA00299 & $8 / 1 / 2000$ & NA & Water & Trip Blank & 1 \\
\hline * & FTA00298 & $8 / 17 / 2000$ & NA & Water & Trip Blank & 1 \\
\hline * & GPB00201 & $7 / 31 / 2000$ & NA & Water & Trip Blank & 1 \\
\hline * & GPB00202 & $8 / 2 / 2000$ & NA & Water & Trip Blank & 1 \\
\hline * & GPB00203 & 8/8/2000 & NA & Water & Trip Blank & 1 \\
\hline GPBA & GPB00203A & $8 / 9 / 2000$ & NA & Water & Trip Blank & 1 \\
\hline GPBA & GPB00204 & $8 / 9 / 2000$ & NA & Water & Trip Blank & 1 \\
\hline GPBA & GPB00205 & $8 / 10 / 2000$ & NA & Water & Trip Blank & 1 \\
\hline GPBA & GPB00206 & $8 / 10 / 2000$ & NA & Water & Trip Blank & 1 \\
\hline GPBA & GPB00207 & $8 / 10 / 2000$ & NA & Water & Trip Blank & 1 \\
\hline GPBA & GPB00208 & $8 / 15 / 2000$ & NA & Water & Trip Blank & 1 \\
\hline GPBA & GPB00209 & $8 / 15 / 2000$ & NA & Water & Trip Blank & 1 \\
\hline GPBA & GPB00210 & $8 / 15 / 2000$ & NA & Water & Trip Blank & 1 \\
\hline GPBA & GPB00211 & $8 / 16 / 2000$ & NA & Water & Field Blank & $1,2,3,4,8,9,11,12,13$ \\
\hline $\begin{array}{l}\text { GPBA-Disposal } \\
\text { Plastic Tools }\end{array}$ & GPB00212 & $8 / 16 / 2000$ & NA & Water & Source Blank & $1,2,3,4,8,9,11,12,13$ \\
\hline GPBA & GPB00213 & $8 / 16 / 2000$ & NA & Water & Trip Blank & 1 \\
\hline GPBA & GPB00214 & $8 / 16 / 2000$ & NA & Water & Field Blank & $1,2,3,4,8,9,11,12,13$ \\
\hline GPBA & GPB00215 & $8 / 16 / 2000$ & NA & Water & Trip Blank & 1 \\
\hline GPBA & GPB00216 & $8 / 16 / 2000$ & NA & Water & Trip Blank & 1 \\
\hline $\begin{array}{c}\text { GPBA-Deconed } \\
\text { Backhoe }\end{array}$ & GPB00217 & $8 / 16 / 2000$ & NA & Water & $\begin{array}{c}\text { Equipment } \\
\text { Rinsate Blank }\end{array}$ & $1,2,3,4,8,9,11,12,13$ \\
\hline SSY & SSY00204 & $7 / 24 / 2000$ & NA & Water & Trip Blank & 1 \\
\hline $\begin{array}{l}\text { SSY-Geoprobe } \\
\text { Liners }\end{array}$ & SSY00205 & $7 / 24 / 2000$ & NA & Water & Source Blank & $1,2,3,4,6,7,10,14$ \\
\hline SSY & SSY00206 & $7 / 24 / 2000$ & NA & Water & Trip Blank & 1 \\
\hline SSY & SSY00207 & $7 / 24 / 2000$ & NA & Water & Field Blank & $1,2,3,4,6,7,10,14$ \\
\hline SSY & SSY00208 & $7 / 25 / 2000$ & NA & Water & Trip Blank & 1 \\
\hline SSY & SSY00209 & $7 / 25 / 2000$ & NA & Water & Field Blank & $1,2,3,4,6,7,10,14$ \\
\hline SSY & SSY00210 & $7 / 26 / 2000$ & NA & Water & Trip Blank & 1 \\
\hline
\end{tabular}


Table A.3-1

CAU 490, Station 44 Burn Area, Tonopah Test Range
Sampling Locations and Analyses

(Page 7 of 7 )

\begin{tabular}{|c|c|c|c|c|c|c|}
\hline Location & $\begin{array}{l}\text { Sample } \\
\text { Number }\end{array}$ & $\begin{array}{c}\text { Date } \\
\text { Collected }\end{array}$ & $\begin{array}{c}\text { Depth } \\
\text { (feet bgs) }\end{array}$ & $\begin{array}{l}\text { Sample } \\
\text { Matrix }\end{array}$ & Sample Type & Analyses \\
\hline $\begin{array}{l}\text { SSY-Geoprobe } \\
\text { Liner }\end{array}$ & SSY00211 & $7 / 26 / 2000$ & NA & Water & Source Blank & $1,2,3,4,6,7,10,14$ \\
\hline SSY & SSY00201 & $7 / 19 / 2000$ & NA & Water & Field Blank & $1,2,3,4,6,7,10,14$ \\
\hline SSY & SSY00202 & $7 / 20 / 2000$ & NA & Water & Trip Blank & 1 \\
\hline $\begin{array}{l}\text { SSY-Deconed } \\
\text { Geoprobe Parts } \\
\text { \& Steel Bowl }\end{array}$ & SSY00203 & $7 / 20 / 2000$ & NA & Water & $\begin{array}{c}\text { Equipment } \\
\text { Rinsate Blank }\end{array}$ & $1,2,3,4,5,6,7,10,14$ \\
\hline SSY & SSY00001 & $7 / 20 / 2000$ & NA & Water & Trip Blank & 1 \\
\hline SSY & SSY00002 & $7 / 24 / 2000$ & NA & Water & Trip Blank & 1 \\
\hline SSY & SSY00003 & $7 / 24 / 2000$ & NA & Water & Trip Blank & 1 \\
\hline SSY & SSY00004 & $7 / 25 / 2000$ & NA & Water & Trip Blank & 1 \\
\hline SSY & SSY00005 & $7 / 25 / 2000$ & NA & Water & Trip Blank & 1 \\
\hline SSY & SSY00006 & $7 / 26 / 2000$ & NA & Water & Trip Blank & 1 \\
\hline SSY & SSY00100 & $7 / 19 / 2000$ & NA & Water & Trip Blank & 1 \\
\hline ST44 & ST4400200 & $7 / 17 / 2000$ & NA & Water & Trip Blank & 1 \\
\hline ST44 & ST4400201 & $7 / 17 / 2000$ & NA & Water & Field Blank & $1,2,3,4,10$ \\
\hline ST44 & ST4400202 & $7 / 17 / 2000$ & NA & Water & Trip Blank & 1 \\
\hline $\begin{array}{l}\text { ST44-Stainless } \\
\text { Steel Bowl }\end{array}$ & ST4400203 & $7 / 17 / 2000$ & NA & Water & $\begin{array}{c}\text { Equipment } \\
\text { Rinsate Blank }\end{array}$ & $1,2,3,4,10$ \\
\hline ST44 & ST4400204 & $7 / 18 / 2000$ & NA & Water & Trip Blank & 1 \\
\hline $\begin{array}{l}\text { ST44-Fire } \\
\text { Hydrant }\end{array}$ & ST4400205 & $7 / 18 / 2000$ & NA & Water & Source Blank & $\begin{array}{c}1,2,3,4,5,7,8,9,10,11 \\
12,14\end{array}$ \\
\hline ST44 & ST4400100 & $7 / 17 / 2000$ & NA & Water & Trip Blank & 1 \\
\hline ST44 & ST4400101 & $7 / 18 / 2000$ & NA & Water & Trip Blank & 1 \\
\hline ST44 & ST4400102 & $7 / 18 / 2000$ & NA & Water & Trip Blank & 1 \\
\hline
\end{tabular}

aTrench 1-10 indicates sample collected 10 feet from the start of Trench 1.

1 - Total VOCs

8 - Isotopic Plutonium

2 - Total SVOCs

3 - TPH (Diesel-Range Organics)

4 - Total RCRA Metals

9 - Isotopic Uranium

10 - Gamma Spectrometry

11 - Nitrocellulose (Paragon-Specific)

5 - TCLP RCRA Metals

12 - Nitroguanidine CRREL 89-35

13 - Nitroaromatics \& Nitramines (to include Nitroglycerine)

7 - Total Pesticides

14 - TPH (Gasoline-Range Organics)

*Prepackaged by off-site laboratory

15 - TCKO VOCs

bgs $=$ Below ground surface (in feet)

$\mathrm{BH}$ - Borehole

N/A - Not applicable

MS/MSD - Matrix spike/matrix spike duplicate

FD = Field Duplicate 


\section{Table A.3-2}

\section{Laboratory Analytical Methods Used for Samples Collected at CAU 490, Station 44 Burn Area, Tonopah Test Range}

\begin{tabular}{|c|c|}
\hline Analytical Parameter & Analytical Method \\
\hline Total volatile organic compounds & EPA $8260 B^{a}$ \\
\hline Total semivolatile organic compounds & EPA $8270 C^{a}$ \\
\hline $\begin{array}{l}\text { Total metals (including RCRA arsenic, barium, cadmium, chromium, lead, selenium, } \\
\text { silver, and mercury) }\end{array}$ & $\begin{array}{l}\text { EPA } 6010 B / 7470 A^{a} \\
\text { EPA } 6010 B / 7471 A^{a}\end{array}$ \\
\hline TCLP RCRA metals (chromium) & EPA $1311 / 6010 B^{a}$ \\
\hline Total petroleum hydrocarbons - gasoline- and diesel-range organics & EPA 8015B (modified) ${ }^{\mathrm{a}}$ \\
\hline Total Pesticides & EPA $8081 A^{a}$ \\
\hline Total PCBs & EPA $8082^{a}$ \\
\hline Nitroglycerine & SW8332a \\
\hline Nitroguanidine & SW8000B $^{a}$, CREL89-35 \\
\hline Nitroaromatics and Nitramines & SW8330a \\
\hline Nitrocellulose & Paragon specific ${ }^{g, h}$ \\
\hline Isotopic Uranium & $\begin{array}{l}\text { ASTM } 3972-97^{b} \\
\text { ASTM C } 1000-90^{b}\end{array}$ \\
\hline Isotopic Plutonium & $\begin{array}{l}\text { ASTM } 3865-97^{c} \\
\text { ASTM C1001-90 }\end{array}$ \\
\hline Gamma Spectrometry & $\begin{array}{l}\text { EPA } 901.1^{\mathrm{e}} \\
\text { HASL } 300^{\mathrm{f}}\end{array}$ \\
\hline
\end{tabular}

aU.S. Environmental Protection Agency. 1996. Test Methods for Evaluation Solid Waste, Physical/Chemical Methods, SW-846, CD ROM PB97-501928GEI, which contains updates for 1986, 1992, 1994, and 1996. Washington, DC.

${ }^{\mathrm{b}}$ American Society for Testing and Materials. 1997a. Standard Test Method for Isotopic Uranium in Water by Radiochemistry, D-3973-97. Philadelphia, PA.

${ }^{\mathrm{C}}$ American Society for Testing and Materials. 1997b. Standard Test Method for Plutonium in Water by Radiochemistry, D-3865. Philadelphia, PA.

dAmerican Society for Testing and Materials. 1997c. Standard Test Method for Strontium-90 in Water by Radiochemistry, D5811-95. Philadelphia, PA.

eU.S. Environmental Protection Agency. 1980. Prescribed Procedures for Measurement of Radioactivity in Drinking Water, EPA-600/4-80-032. Washington, DC.

fU.S. Department of Energy. 1997. The Procedures Manual of the Environmental Measurements Laboratory, Vol. 1, 28th Edition, HASL-300. Washington, DC.

${ }^{9}$ Paragon Analytical Laboratory. 1983. Indiana Army Ammunition Plant Contamination Survey: Analytical Procedure for Nitrocellulose. Fort Collins, CO.

${ }^{\mathrm{h}}$ Paragon Analytical Laboratory. 2000. Nitrocellulose in Water Procedure provided by ERDC, Cold Regions Research and Engineering Laboratory, Hanover, New Hampshire. Fort Collins, CO.

'U.S. Army Corps of Engineers. 2000. Cold Region Research and Engineering Laboratory Special Report: Analytical Methods for Determining Nitroguanidine in Soil and Water. Hanover, New Hampshire. 
soil samples collected at SSY and GPBA detected above minimum reporting limits as specified in the CAIP (DOE/NV, 2000) and the associated PALs are presented in Table A.3-3. None of the soil results exceed the PALs.

\section{A.3.2 Total Semivolatile Organic Compounds}

All SVOC results for soil samples collected at all four CASs were below minimum reporting limits as established in the CAIP (DOE/NV, 2000). Therefore, SVOCs were not detected in soil samples at concentrations exceeding PALs (EPA, 1999).

\section{A.3.3 Total Petroleum Hydrocarbons}

All TPH-gasoline analytical results for soil samples collected at SSY were below minimum reporting limits as established in the CAIP (DOE/NV, 2000).

All TPH-diesel analytical results for soil samples collected at GPBA and STA44 were below minimum reporting limits as established in the CAIP (DOE/NV, 2000). The TPH-diesel analytical results for soil samples detected above minimum reporting limits as specified in the CAIP (DOE/NV, 2000) and the associated PAL are presented in Table A.3-4. Samples from SSY and FTA exceeded the NDEP regulatory action level of $100 \mathrm{mg} / \mathrm{kg}$ for TPH diesel (DOE/NV, 2000; NAC, 1997).

Soil samples collected from SSY at locations B5, B6, B7, B8, and R9 (SSY00105, SSY00106, SSY00106A, SSY00107, SSY00108, SSY00108A, and SSY00117), had concentrations ranging from $110 \mathrm{mg} / \mathrm{kg}$ to $12,000 \mathrm{mg} / \mathrm{kg}$ in the TPH diesel-range. These samples were collected from 0-1 ft bgs, except SSY00106A and SSY00108A were collected at 3-4 ft bgs.

Soil samples collected from FTA at locations E1 and E4 at various depths (FTA00101, FTA00102, FTA00103, FTA00116, and FTA00117) had concentrations ranging from $520 \mathrm{mg} / \mathrm{kg}$ to 6,300 mg/kg in the TPH diesel-range, which also exceeds the NDEP regulatory action level of $100 \mathrm{mg} / \mathrm{kg}$. 
Table A.3-3

Soil Sample Results for Total Volatile Organic Compounds Detected Above Minimum Reporting Limits, CAU 490, Station 44 Burn Area

(Page 1 of 2)

\begin{tabular}{|c|c|c|c|c|c|c|c|c|c|}
\hline \multirow[b]{2}{*}{$\begin{array}{l}\text { Sample } \\
\text { Location }\end{array}$} & \multirow[b]{2}{*}{$\begin{array}{l}\text { Sample } \\
\text { Number }\end{array}$} & \multirow[b]{2}{*}{$\begin{array}{c}\text { Start Depth } \\
\text { (ft) }\end{array}$} & \multirow[b]{2}{*}{$\begin{array}{c}\text { End Depth } \\
\text { (ft) }\end{array}$} & \multicolumn{6}{|c|}{ Contaminants of Potential Concern $(\mu \mathrm{g} / \mathrm{kg})$} \\
\hline & & & & $\begin{array}{l}\text { さ } \\
\stackrel{0}{0} \\
\stackrel{0}{0}\end{array}$ & 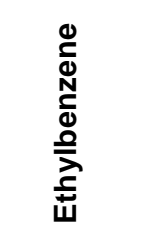 & 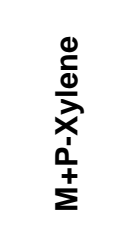 & 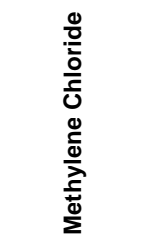 & 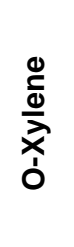 & 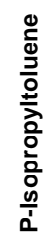 \\
\hline \multicolumn{4}{|c|}{ Preliminary Action Levels ${ }^{a}$} & $6,200,000$ & 230,000 & 210,000 & 21,000 & 210 & NI \\
\hline B3 & SSY00103 & 0 & 1 & $27(\mathrm{~J})^{\mathrm{d}}$ & -- & -- & -- & -- & $\overline{--}$ \\
\hline \multirow{2}{*}{$\mathrm{R} 1$} & SSY00109 & 0 & 1 & -- & -- & -- & $25(\mathrm{~J})^{\mathrm{c}, \mathrm{d}, \mathrm{e}}$ & -- & -- \\
\hline & SSY00109A & 3 & 4 & $24(J)^{d}$ & -- & -- & $25(\mathrm{~J})^{\mathrm{c}, \mathrm{d}, \mathrm{e}}$ & -- & -- \\
\hline $\mathrm{R} 2$ & SSY00110B & 3 & 4 & -- & -- & -- & $34(\mathrm{~J})^{\mathrm{c}, \mathrm{d}, \mathrm{e}}$ & -- & - \\
\hline \multirow{2}{*}{ R3 } & SSY00111 & 0 & 1 & $21(\mathrm{~J})^{\mathrm{d}}$ & -- & -- & $31(\mathrm{~J})^{\mathrm{c}, \mathrm{d}, \mathrm{e}}$ & -- & -- \\
\hline & SSY00111A & 3 & 4 & -- & -- & -- & $26(\mathrm{~J})^{\mathrm{c}, \mathrm{d}, \mathrm{e}}$ & -- & - \\
\hline \multirow{2}{*}{$\mathrm{R} 4$} & SSY00112 & 0 & 1 & -- & -- & -- & $28(J)^{c, d, e}$ & -- & -- \\
\hline & SSY00112A & 3 & 4 & -- & -- & -- & $25(\mathrm{~J})^{\mathrm{c}, \mathrm{d}, \mathrm{e}}$ & -- & -- \\
\hline Trench 3-12 & GPB00111 & 0 & 1 & 46 & -- & 19 & -- & 6.4 & 18 \\
\hline Trench 3-26 & GPB00112 & 0 & 1 & 25 & 6.4 & 25 & -- & 8 & -- \\
\hline Trench 3-30 & GPB00114 & 0 & 1 & 35 & 13 & 51 & -- & 17 & -- \\
\hline Trench 4-0 & GPB00116 & 0 & 1 & 23 & -- & -- & -- & -- & -- \\
\hline Trench 5-6 & GPB00123 & 3 & 4 & 26 & -- & -- & -- & -- & -- \\
\hline Trench 6-6 & GPB00125 & 0 & 1 & 22 & -- & -- & -- & -- & -- \\
\hline Trench 7-0 & GPB00128 & 5 & 6 & 25 & -- & -- & -- & -- & - \\
\hline Trench 7-4 & GPB00129 & 0 & 1 & 53 & -- & -- & -- & -- & -- \\
\hline
\end{tabular}


Table A.3-3

Soil Sample Results for Total Volatile Organic Compounds Detected Above Minimum Reporting Limits, CAU 490, Station 44 Burn Area

(Page 2 of 2)

\begin{tabular}{|c|c|c|c|c|c|c|c|c|c|}
\hline \multirow[b]{2}{*}{$\begin{array}{l}\text { Sample } \\
\text { Location }\end{array}$} & \multirow[b]{2}{*}{$\begin{array}{l}\text { Sample } \\
\text { Number }\end{array}$} & \multirow[b]{2}{*}{$\begin{array}{c}\text { Start Depth } \\
\text { (ft) }\end{array}$} & \multirow[b]{2}{*}{$\begin{array}{l}\text { End Depth } \\
\text { (ft) }\end{array}$} & \multicolumn{6}{|c|}{ Contaminants of Potential Concern $(\mu \mathrm{g} / \mathrm{kg})$} \\
\hline & & & & 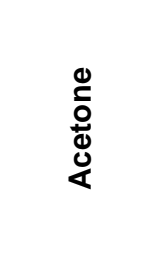 & 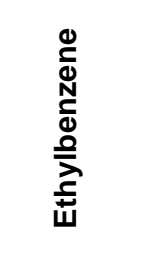 & 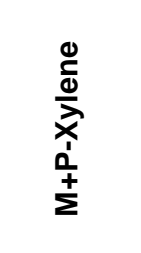 & 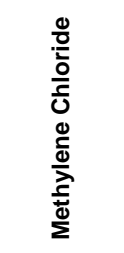 & 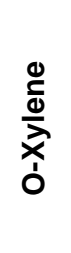 & $\begin{array}{l}\text { ¿ } \\
\frac{0}{0} \\
\frac{0}{0} \\
\frac{1}{2} \\
\frac{0}{0} \\
\frac{0}{0} \\
\frac{0}{1} \\
0\end{array}$ \\
\hline \multicolumn{4}{|c|}{ Preliminary Action Levels ${ }^{a}$} & $6,200,000$ & 230,000 & 210,000 & 21,000 & 210 & NI \\
\hline Trench 8-6 & GPB00131 & 0 & 1 & 150 & -- & $\overline{--}$ & $\overline{--}$ & $\overline{--}$ & -- \\
\hline \multirow{2}{*}{ Trench 9-0 } & GPB00133 & 0 & 1 & $66(\mathrm{~J})^{\mathrm{b}}$ & -- & -- & -- & -- & -- \\
\hline & GPB00134 & 3 & 4 & $33(\mathrm{~J})^{\mathrm{C}}$ & -- & -- & -- & -- & -- \\
\hline \multirow{2}{*}{ Trench 9-12 } & GPB00135 & 0 & 1 & $86(J)^{c}$ & -- & -- & -- & -- & -- \\
\hline & GPB00136 & 3 & 4 & $24(\mathrm{~J})^{\mathrm{C}}$ & -- & -- & -- & -- & -- \\
\hline Trench 9-18 & GPB00137 & 0 & 1 & 27 & -- & -- & -- & -- & -- \\
\hline \multirow{2}{*}{ Trench $10-0$} & GPB00139 & 0 & 1 & 36 & -- & -- & -- & -- & -- \\
\hline & GPB00140 & 0 & 1 & 30 & -- & -- & -- & -- & -- \\
\hline Trench 10-12 & GPB00142 & 0 & 1 & $58(\mathrm{~J})^{\mathrm{C}}$ & -- & -- & -- & -- & -- \\
\hline Trench 10-16 & GPB00144 & 0 & 1 & 23 & -- & -- & -- & -- & -- \\
\hline
\end{tabular}

${ }^{\mathrm{a} E n v i r o n m e n t a l}$ Protection Agency Region 9 Industrial Preliminary Remediation Goals (PRGs) (EPA, 1998)

${ }^{b}$ Internal standard area count exceeded the QC limits

${ }^{\mathrm{C} C o n t i n u i n g ~ C a l i b r a t i o n ~ V e r i f i c a t i o n ~ p e r c e n t ~}>25 \%$

d Sample temperature not documented during storage

${ }^{e}$ Percent Relative Standard Deviation exceeded 30\%

$\mathrm{J}=$ Estimated value

$\mu \mathrm{g} / \mathrm{kg}=$ Micrograms per kilogram

- = Not detected above minimum reporting limit 
Table A.3-4

Soil Sample Results for Total Petroleum Hydrocarbons at CAU 490, Station 44 Burn Area

\begin{tabular}{|c|c|c|c|c|}
\hline \multirow{2}{*}{$\begin{array}{l}\text { Sample } \\
\text { Location }\end{array}$} & \multirow{2}{*}{$\begin{array}{l}\text { Sample } \\
\text { Number }\end{array}$} & \multirow{2}{*}{$\begin{array}{c}\text { Start Depth } \\
\text { (ft) }\end{array}$} & \multirow{2}{*}{$\begin{array}{l}\text { End Depth } \\
\text { (ft) }\end{array}$} & \multirow{2}{*}{$\begin{array}{c}\text { Contaminants of Potential Concern } \\
(\mathrm{mg} / \mathrm{kg})\end{array}$} \\
\hline & & & & \\
\hline \multicolumn{4}{|c|}{ Preliminary Action Level $^{\mathrm{a}}$} & 100 \\
\hline$\overline{\mathrm{B} 1}$ & SSY00101 & 0 & $\overline{11}$ & $24(\mathrm{~J})^{0}$ \\
\hline B2 & SSY00102 & 0 & 1 & $93(\mathrm{~J})^{\mathrm{b}}$ \\
\hline B3 & SSY00103 & 0 & 1 & $45(J)^{b}$ \\
\hline B4 & SSY00104 & 0 & 1 & $70(\mathrm{~J})^{\mathrm{b}}$ \\
\hline \multirow{2}{*}{ B5 } & SSY00105 & 0 & 1 & $560(J)^{b}$ \\
\hline & SSY00105A & 3 & 4 & -- \\
\hline \multirow{2}{*}{ B6 } & SSY00106 & 0 & 1 & $410(\mathrm{~J})^{\mathrm{b}}$ \\
\hline & SSY00106A & 3 & 4 & $110(\mathrm{~J})^{\mathrm{b}}$ \\
\hline \multirow{2}{*}{ B7 } & SSY00107 & 0 & 1 & $220(J)^{b}$ \\
\hline & SSY00107A & 3 & 4 & -- \\
\hline \multirow{2}{*}{ B8 } & SSY00108 & 0 & 1 & $12,000(\mathrm{~J})^{\mathrm{b}, \mathrm{c}, \mathrm{d}}$ \\
\hline & SSY00108A & 3 & 4 & $160(J)^{b}$ \\
\hline \multirow{2}{*}{ R9 } & SSY00117 & 0 & 1 & $910(\mathrm{~J})^{\mathrm{b}}$ \\
\hline & SSY00117A & 3 & 4 & -- \\
\hline \multirow{4}{*}{$\mathrm{E} 1$} & FTA00101 & 0 & 1 & $6,300(J)^{e, f, g}$ \\
\hline & FTA00102 & 3 & 4 & $1,200(J)^{e, f, g}$ \\
\hline & FTA00103 & 9 & 10 & $500(J)^{e, f, g}$ \\
\hline & FTA00104 & 14 & 15 & -- \\
\hline E8 & FTA00113 & 0 & $\overline{1}$ & $55(\mathrm{~J})^{\mathrm{b}}$ \\
\hline \multirow{3}{*}{ E4 } & FTA00116 & 8 & 9 & 910 \\
\hline & FTA00117 & 12 & 13 & 520 \\
\hline & FTA00118 & 15 & 16 & -- \\
\hline
\end{tabular}

${ }^{a}$ Nevada Division of Environmental Protection regulatory action level for total petroleum hydrocarbons (NAC, 1999)

${ }^{\mathrm{b}}$ Sample temperature not documented during storage

${ }^{\mathrm{C}}$ The reported value is from the dilution run

${ }^{d}$ Surrogates diluted out

${ }^{\text {e}}$ Spike recovery was outside of control limits

fLaboratory Control Sample/Laboratory Control Sample Duplicate recovery was below the control limits

${ }^{9}$ Results taken from non-homogeneous sample

$\mathrm{J}=$ Estimated value

-- = Not detected above minimum reporting limit

$\mathrm{mg} / \mathrm{kg}=$ Milligrams per kilogram 


\section{A.3.4 Pesticides}

Pesticide analysis was only performed at SSY. The laboratory results from SSY indicate that pesticide contaminants were not present in soil above the minimum reporting limits as established in the CAIP (DOE/NV, 2000) except for 4,4'-DDT, which was present at $0.55 \mathrm{mg} / \mathrm{kg}$ in sample SSY00120. This sample was "J" qualified because the sample temperature was not documented during storage during characterization. None of the soil results from SSY exceed the PALs.

\section{A.3.5 Total RCRA Metals}

The total RCRA metals for soil samples collected at all four CASs detected above the minimum reporting limits (DOE/NV, 2000) are presented in Table A.3-5. Except for arsenic, all the total RCRA metal results were below PALs (EPA, 1998).

Arsenic was detected above the PAL of $2.7 \mathrm{mg} / \mathrm{kg}$ in most of the samples analyzed. The arsenic concentrations for the samples analyzed ranged from $2.6 \mathrm{mg} / \mathrm{kg}$ to $10.0 \mathrm{mg} / \mathrm{kg}$. The highest concentrations of arsenic $(10 \mathrm{mg} / \mathrm{kg})$ were detected in samples collected from the FTA at a depth of 9-10 ft bgs in sample FTA00103.

The PAL of $2.7 \mathrm{mg} / \mathrm{kg}$ is lower than the 7 to $8 \mathrm{ppm}(\mathrm{mg} / \mathrm{kg})$ mean concentration of arsenic in silt from the Nellis Air Force Range (NBMG, 1998; Moore, 1999) and lower than the range of concentrations of 6 to $43 \mathrm{mg} / \mathrm{kg}$ in soils from locations near the TTR (SNL, 1999). Data from previous sampling efforts in or near Area 3 also reveal arsenic concentrations as high as $24.1 \mathrm{mg} / \mathrm{kg}$ from undisturbed locations (DOE/NV, 1998). Although several arsenic concentrations presented in Table A.3-5 exceed the PAL, these levels are considered representative of ambient conditions at these CASs.

The soil sample (GPB00111) from GPBA had an elevated level of total chromium at $140 \mathrm{mg} / \mathrm{kg}$. This result was estimated because the inductively coupled plasma (ICP) serial dilution recovery was not met. The TCLP for this sample was run for waste management purposes to clarify if it is a RCRA concern for D007 (regulatory limit is $5 \mathrm{mg} / \mathrm{kg}$ from TCLP). The TCLP total chromium result is nondetect. 
Table A.3-5

Soil Sample Results for Total RCRA Metals Detected Above Minimum Reporting Limits, CAU 490, Station 44 Burn Area

(Sheet 1 of 5)

\begin{tabular}{|c|c|c|c|c|c|c|c|c|c|c|c|c|c|c|c|c|c|c|c|c|c|c|}
\hline \multirow[b]{2}{*}{$\begin{array}{l}\text { Sample } \\
\text { Location }\end{array}$} & \multirow[b]{2}{*}{$\begin{array}{l}\text { Sample } \\
\text { Number }\end{array}$} & \multirow[b]{2}{*}{$\begin{array}{c}\text { Start } \\
\text { Depth } \\
\text { (ft) }\end{array}$} & \multirow[b]{2}{*}{$\begin{array}{c}\text { End } \\
\text { Depth } \\
\text { (ft) }\end{array}$} & \multicolumn{19}{|c|}{ Contaminants of Potential Concern $(\mathrm{mg} / \mathrm{kg})$} \\
\hline & & & & $\begin{array}{l}\frac{E}{\underline{\underline{E}}} \\
\frac{\underline{\underline{E}}}{\alpha}\end{array}$ & 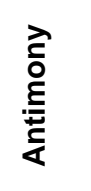 & 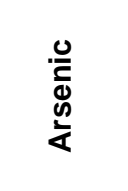 & 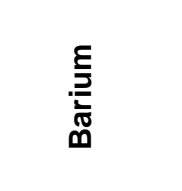 & 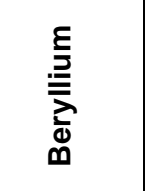 & $\frac{\xi}{\frac{\Xi}{0}}$ & 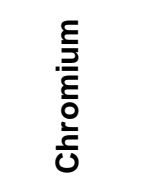 & $\begin{array}{l}\frac{5}{\pi / 0} \\
\frac{0}{0} \\
0\end{array}$ & $\begin{array}{l}\text { むò } \\
\text { 잉 }\end{array}$ & 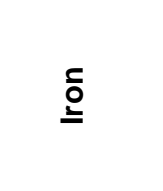 & 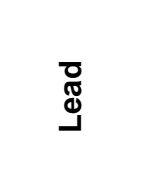 & 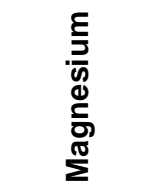 & 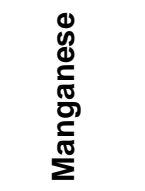 & 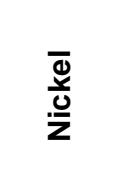 & 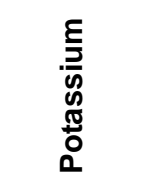 & 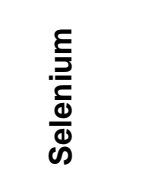 & 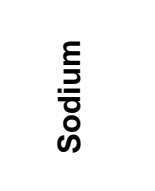 & $\begin{array}{l}\underline{E} \\
\frac{E}{\overline{5}} \\
\frac{5}{5} \\
\frac{5}{7}\end{array}$ & $\stackrel{0}{\stackrel{\underline{N}}{N}}$ \\
\hline \multicolumn{4}{|c|}{ Preliminary Action Levels ${ }^{a}$} & 100,000 & 820 & 2.7 & 100,000 & 2,200 & NI & 450 & 100,000 & 76,000 & 100,000 & 1,000 & NI & 32,000 & 41,000 & $\mathbf{N I}$ & 10,000 & NI & 14,000 & 100,000 \\
\hline \multicolumn{23}{|c|}{ Fire Training Area (CAS 03-56-001-03BA) } \\
\hline \multirow{4}{*}{ E1 } & FTA00101 & 0 & 1 & -- & -- & $5(\mathrm{~J})^{b}$ & $120(J)^{b, c}$ & -- & -- & 8.2 & -- & -- & -- & $12(J)^{b, c}$ & -- & -- & -- & -- & 0.98 & -- & -- & 33 \\
\hline & FTA00102 & 3 & 4 & -- & -- & $3.3(J)^{b}$ & $110(J)^{b, c}$ & -- & -- & 1.6 & -- & -- & -- & $3.4(J)^{b, c}$ & -- & -- & -- & -- & $-\cdot$ & -- & -- & 9.6 \\
\hline & FTA00103 & 9 & 10 & -- & -- & $10(J)^{b}$ & $500(J)^{b, c}$ & -- & -- & 3.5 & -- & -- & -- & $39(\mathrm{~J})^{\mathrm{b}, \mathrm{c}}$ & -- & -- & -- & -- & 0.94 & -- & -- & 21 \\
\hline & FTA00104 & 14 & 15 & -- & -- & $5(\mathrm{~J})^{b}$ & $72(J)^{b, c}$ & -- & -- & 3.4 & -- & -- & -- & $6.4(J)^{\mathrm{b}, \mathrm{c}}$ & -- & -- & -- & -- & $-\cdot$ & -- & -- & 17 \\
\hline \multirow{4}{*}{ E3 } & FTA00105 & 0 & 1 & -- & -- & $4.9(\mathrm{~J})^{\mathrm{b}}$ & $110(J)^{b, c}$ & -- & -- & 6.7 & -- & -- & -- & $11(J)^{b, c}$ & -- & -- & -- & -- & -- & -- & -- & 37 \\
\hline & FTA00106 & 3 & 4 & -- & -- & $8.4(J)^{b}$ & $81(J)^{b, c}$ & -- & -- & 4.6 & -- & -- & -- & $9.5(J)^{b, c}$ & -- & -- & -- & -- & -- & -- & -- & 23 \\
\hline & FTA00107 & 8 & 9 & -- & -- & $4(\mathrm{~J})^{b}$ & $80(\mathrm{~J})^{b, c}$ & -- & -- & 2.8 & -- & -- & -- & $5.5(J)^{b, c}$ & -- & -- & -- & -- & -- & -- & -- & 16 \\
\hline & FTA00108 & 14 & 15 & -- & -- & $4.9(\mathrm{~J})^{b}$ & $180(J)^{b, c}$ & -- & -- & 4.6 & -- & -- & -- & $7.8(J)^{b, c}$ & -- & -- & -- & -- & -- & -- & -- & 20 \\
\hline \multirow{4}{*}{ E6 } & FTA00109 & 0 & 1 & -- & -- & $4.8(J)^{b}$ & $110(\mathrm{~J})^{\mathrm{b}, \mathrm{c}}$ & -- & -- & 5.4 & -- & -- & -- & $10(J)^{b, c}$ & -- & -- & -- & -- & -- & -- & -- & 38 \\
\hline & FTA00110 & 3 & 4 & -- & -- & $6.4(J)^{b}$ & $66(J)^{b, c}$ & -- & -- & 1.9 & -- & -- & -- & $5(J)^{b, c}$ & -- & -- & -- & -- & -- & -- & -- & 12 \\
\hline & FTA00111 & 8 & 9 & -- & -- & $5.5(J)^{b}$ & $85(J)^{b, c}$ & -- & -- & 2.8 & -- & -- & -- & $9.3(\mathrm{~J})^{\mathrm{b}, \mathrm{c}}$ & -- & -- & -- & -- & -- & -- & -- & 18 \\
\hline & FTA00112 & 14 & 15 & -- & -- & $5.6(J)^{b}$ & $140(J)^{b, c}$ & -- & -- & 4.4 & -- & -- & -- & $9.3(\mathrm{~J})^{\mathrm{b}, \mathrm{c}}$ & -- & -- & -- & -- & -- & -- & -- & 22 \\
\hline \multirow{3}{*}{$\begin{array}{l}\text { North/South } \\
\text { Trench }\end{array}$} & FTA00113 & 0 & 1 & -- & -- & $4.6(\mathrm{~J})^{\mathrm{d}}$ & $100(J)^{d}$ & -- & -- & $6.2(\mathrm{~J})^{\mathrm{d}}$ & -- & -- & -- & $9.6(\mathrm{~J})^{\mathrm{d}}$ & -- & -- & -- & -- & -- & -- & -- & $29(J)^{d}$ \\
\hline & FTA00114 & 8 & 9 & -- & -- & $4.5(J)^{d}$ & $66(\mathrm{~J})^{\mathrm{d}}$ & -- & -- & $2.2(\mathrm{~J})^{d}$ & -- & -- & -- & $5.5(\mathrm{~J})^{\mathrm{d}}$ & -- & -- & -- & -- & -- & -- & -- & $14(\mathrm{~J})^{\mathrm{d}}$ \\
\hline & FTA00115 & 8 & 9 & -- & -- & $3.2(J)^{d}$ & $57(J)^{d}$ & -- & -- & $1.6(J)^{d}$ & -- & -- & -- & $4.3(J)^{d}$ & -- & -- & -- & -- & -- & -- & -- & $9.2(J)^{d}$ \\
\hline \multirow{3}{*}{ E4 } & FTA00116 & 8 & 9 & -- & -- & 5.4 & $160(J)^{b, c, e}$ & -- & -- & 3.4 & -- & -- & -- & 8.4 & -- & -- & -- & -- & -- & -- & -- & 18 \\
\hline & FTA00117 & 12 & 13 & -- & -- & 6 & $110(J)^{b, c, e}$ & -- & -- & 4.5 & -- & -- & -- & 7.9 & -- & -- & -- & -- & -- & -- & -- & 21 \\
\hline & FTA00118 & 15 & 16 & -- & -- & 5.1 & $72(J)^{b, c, e}$ & -- & -- & 4.1 & -- & -- & -- & 7.6 & -- & -- & -- & -- & -- & -- & -- & 20 \\
\hline \multicolumn{23}{|c|}{ Gun Propellant Burn Area (CAS 09-54-001-09L2) } \\
\hline \multirow{2}{*}{ Trench 1-0 } & GPB00101 & 0 & 1 & $11,000(J)^{d}$ & -- & $7.4(J)^{d}$ & $140(J)^{d}$ & $1.2(\mathrm{~J})^{\mathrm{d}}$ & $10,000(J)^{d}$ & $8.1(J)^{d}$ & $6.7(\mathrm{~J})^{\mathrm{d}}$ & $11(\mathrm{~J})$ & $13,000(J)^{d}$ & $11(J)^{d}$ & $5,700(J)^{d}$ & $460(J)^{d}$ & $9.3(J)^{d}$ & $4,800(J)^{d}$ & -- & $450(\mathrm{~J})^{d}$ & $20(J)^{d}$ & $37(J)^{d}$ \\
\hline & GPB00102 & 3 & 4 & $5,900(J)^{d}$ & -- & $3.9(\mathrm{~J})^{d}$ & $64(J)^{d}$ & $0.58(\mathrm{~J})^{\mathrm{d}}$ & $6,500(J)^{d}$ & $4.2(J)^{d}$ & $3(\mathrm{~J})^{d}$ & $6(\mathrm{~J})^{\mathrm{d}}$ & $6,600(J)^{d}$ & $5.4(J)^{d}$ & $3,200(J)^{d}$ & $190(\mathrm{~J})^{d}$ & $4.3(\mathrm{~J})^{\mathrm{d}}$ & $3,200(\mathrm{~J})^{d}$ & $-\cdot$ & $670(\mathrm{~J})^{d}$ & $10(J)^{d}$ & $20(J)^{d}$ \\
\hline \multirow{2}{*}{ Trench 1-15 } & GPB00103 & 0 & 1 & $7,600(J)^{d}$ & -- & $4.5(\mathrm{~J})^{\mathrm{d}}$ & $83(J)^{d}$ & $0.74(J)^{d}$ & $7,900(J)^{d}$ & $4.9(\mathrm{~J})^{\mathrm{d}}$ & $3.6(\mathrm{~J})^{\mathrm{d}}$ & $7.5(\mathrm{~J})^{\mathrm{d}}$ & $8,100(J)^{d}$ & $6.4(J)^{d}$ & $4,100(\mathrm{~J})^{\mathrm{d}}$ & $250(J)^{d}$ & $5.3(J)^{d}$ & $4,100(J)^{d}$ & $0.53(\mathrm{~J})^{\mathrm{d}}$ & $830(\mathrm{~J})^{d}$ & $12(J)^{d}$ & $24(J)^{d}$ \\
\hline & GPB00104 & 3 & 4 & $5,900(\mathrm{~J})^{\mathrm{d}}$ & -- & $4.4(\mathrm{~J})^{\mathrm{d}}$ & $65(J)^{d}$ & $0.59(\mathrm{~J})^{\mathrm{d}}$ & $7,700(\mathrm{~J})^{d}$ & $4.1(\mathrm{~J})^{\mathrm{d}}$ & $3.1(\mathrm{~J})^{\mathrm{d}}$ & $6.1(\mathrm{~J})^{\mathrm{d}}$ & $6,600(\mathrm{~J})^{d}$ & $5.3(\mathrm{~J})^{\mathrm{d}}$ & $3,300(\mathrm{~J})^{\mathrm{d}}$ & $200(\mathrm{~J})^{d}$ & $4.2(J)^{d}$ & $3,100(\mathrm{~J})^{d}$ & -- & $600(\mathrm{~J})^{d}$ & $11(J)^{d}$ & $19(J)^{d}$ \\
\hline \multirow{2}{*}{ Trench 1-30 } & GPB00105 & 0 & 1 & $7,200(J)^{d}$ & -- & $5.7(J)^{d}$ & $73(\mathrm{~J})^{\mathrm{d}}$ & $0.74(\mathrm{~J})^{\mathrm{d}}$ & $9,100(\mathrm{~J})^{\mathrm{d}}$ & $5.1(J)^{d}$ & $3.9(\mathrm{~J})^{\mathrm{d}}$ & $7.5(J)^{d}$ & $8,100(\mathrm{~J})^{\mathrm{d}}$ & $6.4(J)^{d}$ & $4,000(\mathrm{~J})^{\mathrm{d}}$ & $250(J)^{d}$ & $5.3(\mathrm{~J})^{\mathrm{d}}$ & $3,200(J)^{d}$ & -- & $420(\mathrm{~J})^{d}$ & $13(J)^{d}$ & $23(J)^{d}$ \\
\hline & GPB00106 & 3 & 4 & $2,200(\mathrm{~J})^{\mathrm{d}}$ & -- & $2.7(J)^{d}$ & $32(J)^{d}$ & -- & $1,800(\mathrm{~J})^{\mathrm{d}}$ & $1.8(\mathrm{~J})^{\mathrm{d}}$ & $1.4(\mathrm{~J})^{\mathrm{d}}$ & $2.5(J)^{d}$ & $3,400(\mathrm{~J})^{\mathrm{d}}$ & $2.6(J)^{d}$ & $1,400(\mathrm{~J})^{\mathrm{d}}$ & $79(\mathrm{~J})^{\mathrm{d}}$ & $1.6(J)^{d}$ & $1,300(J)^{d}$ & -- & $420(\mathrm{~J})^{d}$ & $6.2(\mathrm{~J})^{d}$ & $8.2(J)^{d}$ \\
\hline \multirow{2}{*}{ Trench 2-0 } & GPB00107 & 0 & 1 & $5,600(\mathrm{~J})^{d}$ & -- & $4.7(J)^{d}$ & $61(J)^{d}$ & $0.59(\mathrm{~J})^{d}$ & $9,800(J)^{d}$ & $3.8(\mathrm{~J})^{\mathrm{d}}$ & $3(\mathrm{~J})^{\mathrm{d}}$ & $6.1(\mathrm{~J})^{d}$ & $6,200(\mathrm{~J})^{d}$ & $5.3(\mathrm{~J})^{\mathrm{d}}$ & $3,400(J)^{d}$ & $220(\mathrm{~J})^{d}$ & $4.2(J)^{d}$ & $3,300(\mathrm{~J})^{d}$ & -- & $1,100(J)^{d}$ & $10(J)^{d}$ & $19(J)^{d}$ \\
\hline & GPB00108 & 3 & 4 & $5,200(\mathrm{~J})^{\mathrm{d}}$ & -- & $5.1(\mathrm{~J})^{\mathrm{d}}$ & $50(\mathrm{~J})^{\mathrm{d}}$ & -- & $25,000(\mathrm{~J})^{\mathrm{d}}$ & $3.8(J)^{d}$ & $2.6(\mathrm{~J})^{\mathrm{d}}$ & $5(J)^{d}$ & $5,700(\mathrm{~J})^{\mathrm{d}}$ & $4.4(\mathrm{~J})^{\mathrm{d}}$ & $3,200(\mathrm{~J})^{\mathrm{d}}$ & $170(J)^{d}$ & $3.6(J)^{d}$ & $3,000(\mathrm{~J})^{\mathrm{d}}$ & -- & $1,300(\mathrm{~J})^{\mathrm{d}}$ & $11(J)^{d}$ & $17(\mathrm{~J})^{\mathrm{d}}$ \\
\hline \multirow{2}{*}{ Trench 3-0 } & GPB00109 & 0 & 1 & 4,200 & -- & 2.6 & 73 & -- & 3,200 & $2.7(\mathrm{~J})^{\mathrm{e}, \mathrm{f}}$ & $2.2(\mathrm{~J})^{\mathrm{e}, \mathrm{f}}$ & 9.9 & 5,500 & 4.5 & 2,500 & 190 & 2.7 & 2,400 & -- & $140(J)^{e, f}$ & 8.4 & 15 \\
\hline & GPB00110 & 3 & 4 & 3,100 & -- & 3.4 & 40 & -- & 2,800 & $2.5(\mathrm{~J})^{\dagger}$ & $1.7(J)^{\dagger}$ & 4.9 & 4,500 & 2.9 & 1,700 & 93 & -- & 1,700 & -- & $550(\mathrm{~J})^{\dagger}$ & 11 & 11 \\
\hline
\end{tabular}


Table A.3-5

Soil Sample Results for Total RCRA Metals Detected Above Minimum Reporting Limits, CAU 490, Station 44 Burn Area

(Sheet 2 of 5)

\begin{tabular}{|c|c|c|c|c|c|c|c|c|c|c|c|c|c|c|c|c|c|c|c|c|c|c|}
\hline \multirow[b]{2}{*}{$\begin{array}{l}\text { Sample } \\
\text { Location }\end{array}$} & \multirow[b]{2}{*}{$\begin{array}{l}\text { Sample } \\
\text { Number }\end{array}$} & \multirow[b]{2}{*}{$\begin{array}{c}\text { Start } \\
\text { Depth } \\
\text { (ft) }\end{array}$} & \multirow[b]{2}{*}{$\begin{array}{c}\text { End } \\
\text { Depth } \\
\text { (ft) }\end{array}$} & \multicolumn{19}{|c|}{ Contaminants of Potential Concern $(\mathrm{mg} / \mathrm{kg})$} \\
\hline & & & & 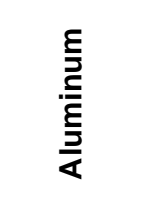 & 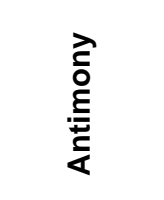 & 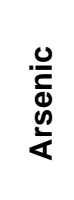 & 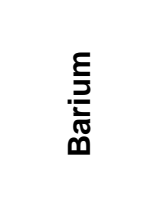 & 趇 & $\begin{array}{l}\frac{E}{\overline{0}} \\
\frac{\overline{0}}{\bar{\delta}} \\
0\end{array}$ & 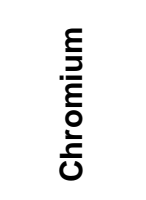 & 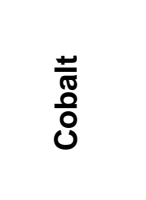 & 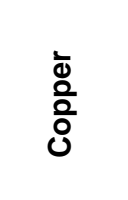 & $\underline{\underline{\underline{\sigma}}}$ & $\stackrel{\square}{\Xi}$ & 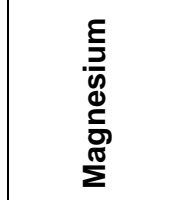 & 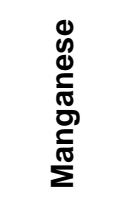 & $\begin{array}{l}\overline{\mathbb{\Phi}} \\
\stackrel{\grave{\iota}}{z}\end{array}$ & 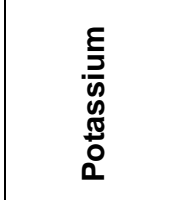 & 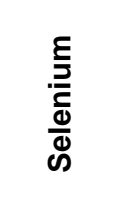 & 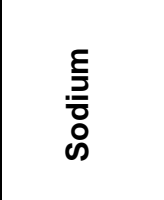 & 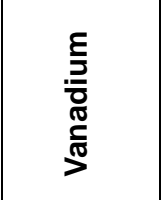 & $\stackrel{\mathscr{I}}{N}$ \\
\hline \multicolumn{4}{|c|}{ Preliminary Action Levels $^{a}$} & 100,000 & 820 & 2.7 & 100,000 & 2,200 & NI & 450 & 100,000 & 76,000 & 100,000 & 1,000 & $\mathrm{NI}$ & 32,000 & 41,000 & $\mathrm{NI}$ & 10,000 & $\mathbf{N I}$ & 14,000 & 100,000 \\
\hline \multicolumn{23}{|c|}{$\frac{1}{2 \text { Gun Propellant Burn Area (CAS 09-54-001-09L2) }}$} \\
\hline Trench 3-12 & GPB00111 & 0 & 1 & 3,800 & -- & 4.5 & 66 & -- & 5,200 & $140(J)^{f}$ & $3.1(\mathrm{~J})^{\dagger}$ & 19 & 21,000 & 12 & 2,200 & 230 & 7.6 & 2,200 & -- & $290(\mathrm{~J})^{\dagger}$ & 9.2 & 24 \\
\hline \multirow{2}{*}{ Trench 3-26 } & GPB00112 & 0 & 1 & 4,600 & -- & 3.7 & 70 & -- & 11,000 & $3.1(\mathrm{~J})^{\dagger}$ & $2.4(\mathrm{~J})^{\mathrm{t}}$ & 11 & 5,800 & 8 & 2,900 & 190 & 3.1 & 3,000 & -- & $480(\mathrm{~J})^{\dagger}$ & 9.1 & 17 \\
\hline & GPB00113 & 3 & 4 & 4,000 & -- & 3.7 & 49 & -- & 13,000 & $3.2(\mathrm{~J})^{t}$ & $2.1(\mathrm{~J})^{t}$ & 3.9 & 5,200 & 3.7 & 2,600 & 120 & 2.7 & 2,400 & -- & $1,100(\mathrm{~J})^{\dagger}$ & 9.6 & 13 \\
\hline \multirow{2}{*}{ Trench 3-30 } & GPB00114 & 0 & 1 & 4,000 & -- & 3.1 & 75 & -- & 6,400 & $2.6(\mathrm{~J})^{t}$ & $2.1(\mathrm{~J})^{\mathrm{f}}$ & 5.6 & 5,200 & 6.3 & 2,400 & 180 & 2.5 & 2,600 & -- & $330(\mathrm{~J})^{\dagger}$ & 8.4 & 15 \\
\hline & GPB00115 & 3 & 4 & 5,600 & -- & 3.7 & 85 & $0.56(J)^{f}$ & 7,500 & $3.7(\mathrm{~J})^{\dagger}$ & $2.9(\mathrm{~J})^{\mathrm{f}}$ & 8.1 & 6,700 & 11 & 3,200 & 220 & 3.8 & 3,200 & -- & $690(\mathrm{~J})^{\mathrm{f}}$ & 10 & 20 \\
\hline \multirow{2}{*}{ Trench 4-0 } & GPB00116 & 0 & 1 & 5,900 & -- & 4.1 & 78 & $0.57(\mathrm{~J})^{f}$ & 9,400 & $4.3(\mathrm{~J})$ & $3.2(J)^{f}$ & 14 & 7,100 & 17 & 3,400 & 240 & 4.1 & 3,400 & -- & $580(\mathrm{~J})^{\dagger}$ & 11 & 33 \\
\hline & GPB00117 & 3 & 4 & 3,200 & -- & 2.6 & 69 & -- & 4,200 & $2.4(\mathrm{~J})^{\mathrm{f}}$ & $1.7(\mathrm{~J})^{\mathrm{f}}$ & 4.3 & 4,500 & 4.1 & 2,000 & 160 & 2.2 & 2,100 & -- & $390(\mathrm{~J})^{\mathrm{f}}$ & 7 & 12 \\
\hline \multirow{2}{*}{ Trench 4-2 } & GPB00118 & 20 & 22 & 5,900 & -- & 8.5 & 90 & $0.68(J)^{f}$ & 6,100 & 4.4 & $4.2(J)^{t}$ & 6 & 8,200 & 8 & 3,300 & 270 & $4.7(\mathrm{~J})^{\mathrm{t}}$ & 2,900 & -- & 1,200 & 17 & 21 \\
\hline & GPB00119 & 20 & 22 & 6,700 & -- & 9.2 & 99 & $0.76(\mathrm{~J})^{t}$ & 6,400 & 4.9 & $4.5(\mathrm{~J})^{\dagger}$ & 6.4 & 9,100 & 8 & 3,600 & 280 & $5.1(\mathrm{~J})^{\mathrm{f}}$ & 3,100 & -- & 1,300 & 18 & 24 \\
\hline Trench 4-10 & GPB00121 & 3 & 4 & 4,300 & -- & 4.4 & 51 & -- & 7,400 & 3.5 & $2.5(\mathrm{~J})^{\mathrm{f}}$ & 4.1 & 5,900 & 4.4 & 2,600 & 160 & $3.3(\mathrm{~J})^{\dagger}$ & 2,500 & -- & 1,300 & 11 & 16 \\
\hline \multirow{2}{*}{ Trench 5-6 } & GPB00122 & 0 & 1 & 5,100 & -- & 3.7 & 89 & $0.51(J)^{f}$ & 6,300 & 3.5 & $2.9(\mathrm{~J})^{\mathrm{f}}$ & 6.9 & 6,600 & 7.2 & 3,100 & 240 & $3.8(\mathrm{~J})^{\mathrm{f}}$ & 3,100 & 0.61 & 400 & 10 & 19 \\
\hline & GPB00123 & 3 & 4 & 7,400 & -- & 8.9 & 100 & $0.71(J)^{f}$ & 51,000 & 5.5 & $3.7(\mathrm{~J})^{\mathrm{f}}$ & 6.4 & 8,900 & 6.5 & 4,800 & 280 & $5.4(\mathrm{~J})^{f}$ & 4,700 & -- & 1,900 & 22 & 26 \\
\hline \multirow{2}{*}{ Trench 6-6 } & GPB00125 & 0 & 1 & 6,400 & -- & 5 & 95 & $0.68(J)^{\dagger}$ & 18,000 & 4.4 & $3.3(\mathrm{~J})^{f}$ & 6.2 & 7,600 & 6 & 3,800 & 230 & $4.6(J)^{t}$ & 4,000 & -- & 630 & 12 & 21 \\
\hline & GPB00126 & 3 & 4 & 6,800 & -- & 7.9 & 96 & $0.69(J)^{t}$ & 59,000 & 5.1 & $3.3(\mathrm{~J})^{\mathrm{f}}$ & 5.9 & 8,000 & 6.5 & 4,600 & 270 & $4.9(\mathrm{~J})^{\dagger}$ & 4,700 & -- & 1,400 & 17 & 23 \\
\hline \multirow{2}{*}{ Trench 7-0 } & GPB00127 & 0 & 1 & 5,500 & -- & 4.1 & 87 & $0.6(\mathrm{~J})^{t}$ & 11,000 & 4.2 & $3.2(\mathrm{~J})^{t}$ & 8.5 & 7,100 & 9.2 & 3,300 & 230 & $4.3(\mathrm{~J})^{\dagger}$ & 3,500 & -- & 600 & 11 & 26 \\
\hline & GPB00128 & 5 & 6 & 3,900 & -- & 3.9 & 68 & -- & 18,000 & 3.1 & $2.3(\mathrm{~J})^{\mathrm{f}}$ & 4 & 5,200 & 4.1 & 2,500 & 150 & $2.9(\mathrm{~J})^{\mathrm{f}}$ & 2,400 & -- & 1,100 & 10 & 18 \\
\hline \multirow{2}{*}{ Trench 7-4 } & \begin{tabular}{|l} 
GPB00129 \\
\end{tabular} & 0 & 1 & 5,300 & -- & 4.3 & 84 & $0.57(J)^{f}$ & 8,800 & 4.3 & $3.1(\mathrm{~J})^{t}$ & 9.2 & 7,400 & 7.6 & 3,200 & 230 & $4.4(\mathrm{~J})^{t}$ & 3,300 & -- & 710 & 12 & 21 \\
\hline & GPB00130 & 3 & 4 & 3,900 & -- & 3.9 & 47 & -- & 4,600 & 3.1 & $2(J)^{f}$ & 5.4 & 5,400 & 5.6 & 2,100 & 130 & $2.8(\mathrm{~J})^{t}$ & 2,100 & -- & 950 & 10 & 15 \\
\hline \multirow{3}{*}{ Trench 8-6 } & GPB00131 & 0 & 1 & 5,100 & -- & 3.6 & 84 & $0.54(\mathrm{~J})^{f}$ & 7,300 & 3.7 & $2.8(\mathrm{~J})^{\mathrm{f}}$ & 6.3 & 6,600 & 6.5 & 3,000 & 230 & $3.9(\mathrm{~J})^{\mathrm{f}}$ & 3,100 & -- & 530 & 11 & 19 \\
\hline & GPB00132 & 3 & 4 & 6,600 & -- & 6.6 & 99 & $0.68(\mathrm{~J})^{f}$ & 30,000 & 5.2 & $3.6(\mathrm{~J})^{\mathrm{f}}$ & 12 & 8,100 & 7.5 & 4,100 & 280 & $4.9(\mathrm{~J})^{\mathrm{f}}$ & 3,800 & -- & 1,900 & 16 & 25 \\
\hline & GPB00920 & & & 5,700 & -- & 4.5 & 89 & $0.59(J)^{\dagger}$ & 8,900 & 4.3 & $3.2(\mathrm{~J})^{\mathrm{f}}$ & 6.5 & 7,600 & 6.3 & 3,200 & 240 & $4.4(\mathrm{~J})^{\mathrm{f}}$ & 3,100 & -- & 860 & 13 & 23 \\
\hline \multirow{2}{*}{ Trench 9-0 } & GPB00133 & 0 & 1 & 5,500 & -- & 3.4 & $91(\mathrm{~J})^{\mathrm{c}, \mathrm{e}}$ & $0.59(\mathrm{~J})^{\dagger}$ & 4,400 & $3.7(\mathrm{~J})^{c, e}$ & 3.2 & 5.7 & 6,800 & 5.4 & $3,400\left(\mathrm{~J} \mathrm{~J}^{c, e}\right.$ & 240 & $4.3(\mathrm{~J})^{t}$ & $3,500(\mathrm{~J}) \mathrm{J}^{\mathrm{c}, \mathrm{e}}$ & -- & 630 & $9.8(\mathrm{~J})^{c, e}$ & $20(J)^{c, e, f}$ \\
\hline & GPB00134 & 3 & 4 & 7,400 & -- & 7.3 & $97(\mathrm{~J})^{\mathrm{c}, \mathrm{e}}$ & $0.82(J)^{f}$ & 32,000 & $5.7(J)^{c, e}$ & 4.1 & 6.4 & 9,100 & 7.1 & $4,300\left(J J^{c, e}\right.$ & 310 & $5.5(J)^{t}$ & $3,900(\mathrm{~J})^{\mathrm{c}, e}$ & -- & 2,300 & $18(J)^{c, e}$ & $26\left(J^{c}\right)^{c, e, f}$ \\
\hline \multirow{2}{*}{ Trench 9-12 } & GPB00135 & 0 & 1 & 6,300 & -- & 4.7 & $99(\mathrm{~J})^{\mathrm{c}, \mathrm{e}}$ & $0.71(\mathrm{~J})^{f}$ & 8,700 & $4.8(\mathrm{~J})^{\mathrm{c}, \mathrm{e}}$ & 3.9 & 6.7 & 8,100 & 6.4 & $3,800\left(\mathrm{~J} \mathrm{~J}^{c, e}\right.$ & 250 & $5.1(\mathrm{~J})^{t}$ & $3,800(\mathrm{~J})^{\mathrm{c}, \mathrm{e}}$ & $-\cdot$ & 970 & $13(J)^{c, e}$ & $23(J)^{c, e, f}$ \\
\hline & GPB00136 & 3 & 4 & 5,200 & -- & 4.5 & $81(J)^{c, e}$ & $0.55(J)^{\dagger}$ & 13,000 & $4.1(J)^{c, e}$ & 2.9 & 5.2 & 6,600 & 5 & $3,200(\mathrm{~J} J)^{c, e}$ & 200 & $3.9(\mathrm{~J})^{\mathrm{f}}$ & $2,800(\mathrm{~J})^{\mathrm{c}, \mathrm{e}}$ & -- & 890 & $11(\mathrm{~J})^{\mathrm{c}, \mathrm{e}}$ & $19(J)^{c, e, f}$ \\
\hline \multirow{2}{*}{ Trench 9-18 } & GPB00137 & 0 & 1 & 8,000 & -- & 4.1 & $100(J)^{c, e}$ & $0.86(\mathrm{~J})^{\dagger}$ & 7,600 & $5.4(\mathrm{~J})^{\mathrm{c}, \mathrm{e}}$ & 4.5 & 8 & 9,400 & 7.4 & $4,600\left(\mathrm{~J} J^{c, e}\right.$ & 300 & $6.3(\mathrm{~J})^{t}$ & $4,600(\mathrm{~J} J)^{c, e}$ & -- & 600 & $13(J)^{c, e}$ & $27\left(J J^{c}, e, f\right.$ \\
\hline & GPB00138 & 3 & 4 & 6,900 & -- & 6.3 & $84(\mathrm{~J})^{\mathrm{c}, \mathrm{e}}$ & $0.73(\mathrm{~J})^{f}$ & 24,000 & $5.1(J)^{\mathrm{c}, \mathrm{e}}$ & 3.7 & 6.2 & 8,300 & 6.3 & $4,300(\mathrm{~J})^{c, e}$ & 260 & $5.3(\mathrm{~J})^{\mathrm{f}}$ & $3,800(\mathrm{~J})^{\mathrm{c}, \mathrm{e}}$ & -- & 1,500 & $15(J)^{\mathrm{c}, \mathrm{e}}$ & $24(J)^{c, e, f}$ \\
\hline \multirow{3}{*}{ Trench 10-0 } & GPB00139 & 0 & 1 & 5,900 & -- & 3.7 & $86(J)^{c, e}$ & $0.63(J)^{f}$ & 7,500 & $4(J)^{c, e}$ & 3.2 & 5.6 & 7,300 & 5.6 & $3,800(J)^{c, e}$ & 220 & $4.4(\mathrm{~J})^{\mathrm{f}}$ & $3,600(\mathrm{~J})^{\mathrm{c}, \mathrm{e}}$ & 0.53 & 220 & $11(J)^{c, e}$ & $21(\mathrm{~J})^{\mathrm{c}, \mathrm{e}, \mathrm{f}}$ \\
\hline & GPB00140 & 0 & 1 & 5,600 & $2.1(\mathrm{~J})^{\mathrm{c}, \mathrm{e}}$ & 3.7 & $87(\mathrm{~J})^{\mathrm{c}, \mathrm{e}}$ & $0.6(J)^{t}$ & 7,700 & $3.8(\mathrm{~J})^{\mathrm{c}, \mathrm{e}}$ & 3.2 & 5.4 & 6,900 & 5.2 & $3,700(\mathrm{~J})^{\mathrm{c}, \mathrm{e}}$ & 220 & $4.3(\mathrm{~J})^{\mathrm{f}}$ & $3,500(\mathrm{~J})^{\mathrm{c}, \mathrm{e}}$ & -- & 210 & $10(J)^{c, e}$ & $20(J)^{c, e, f}$ \\
\hline & GPB00141 & 3 & 4 & 8,200 & -- & 6.9 & $100(J)^{\mathrm{c}, ~ e}$ & $0.85(J)^{\dagger}$ & 52,000 & $6.7(\mathrm{~J})^{\mathrm{c}, \mathrm{e}}$ & 4.3 & 6.5 & 10,000 & 7.4 & $5,200(\mathrm{~J})^{\mathrm{c}, \mathrm{e}}$ & 350 & $6(\mathrm{~J})^{t}$ & $5,300(\mathrm{~J})^{\mathrm{c}, \mathrm{e}}$ & -- & 2,900 & $19(\mathrm{~J})^{c, e}$ & $30(\mathrm{~J})^{\mathrm{c}, \mathrm{e}, \mathrm{f}}$ \\
\hline
\end{tabular}


Table A.3-5

Soil Sample Results for Total RCRA Metals Detected Above Minimum Reporting Limits, CAU 490, Station 44 Burn Area

(Sheet 3 of 5)

\begin{tabular}{|c|c|c|c|c|c|c|c|c|c|c|c|c|c|c|c|c|c|c|c|c|c|c|}
\hline \multirow[b]{2}{*}{$\begin{array}{l}\text { Sample } \\
\text { Location }\end{array}$} & \multirow[b]{2}{*}{$\begin{array}{l}\text { Sample } \\
\text { Number }\end{array}$} & \multirow[b]{2}{*}{$\begin{array}{c}\text { Start } \\
\text { Depth } \\
\text { (ft) }\end{array}$} & \multirow[b]{2}{*}{$\begin{array}{c}\text { End } \\
\text { Depth } \\
\text { (ft) }\end{array}$} & \multicolumn{19}{|c|}{ Contaminants of Potential Concern $(\mathrm{mg} / \mathrm{kg})$} \\
\hline & & & & $\begin{array}{l}\frac{E}{\underline{\underline{E}}} \\
\frac{\bar{E}}{\overline{\underline{E}}}\end{array}$ & 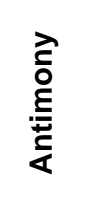 & 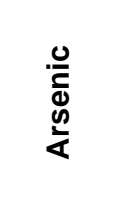 & 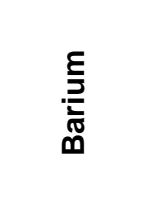 & 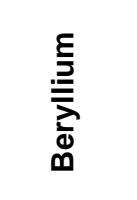 & $\begin{array}{l}\frac{E}{\bar{U}} \\
\frac{\bar{U}}{\delta} \\
0\end{array}$ & 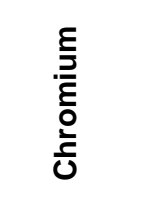 & $\begin{array}{l}\frac{ \pm}{\overline{0}} \\
\text { ŏ } \\
0\end{array}$ & $\begin{array}{l}\text { ळे } \\
\frac{0}{0} \\
0\end{array}$ & $\underline{\underline{\underline{o}}}$ & $\stackrel{乛}{\Xi}$ & 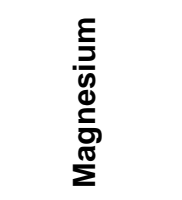 & 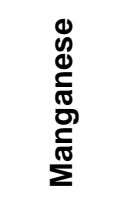 & 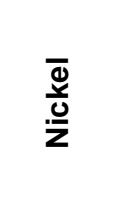 & 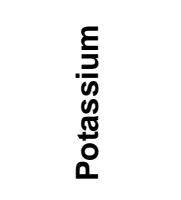 & 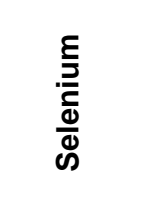 & 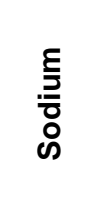 & 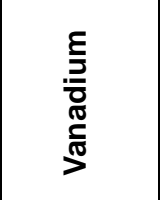 & $\stackrel{0}{\bar{N}}$ \\
\hline \multicolumn{4}{|c|}{ Preliminary Action Levels ${ }^{\mathrm{a}}$} & 100,000 & 820 & 2.7 & 100,000 & 2,200 & $\mathbf{N I}$ & 450 & 100,000 & 76,000 & 100,000 & 1,000 & $\mathbf{N I}$ & 32,000 & 41,000 & $\mathbf{N I}$ & 10,000 & NI & 14,000 & 100,000 \\
\hline \multicolumn{23}{|c|}{ Gun Propellant Burn Area (CAS 09-54-001-09L2) } \\
\hline \multirow{2}{*}{$\begin{array}{c}\text { Trench } \\
10-12\end{array}$} & GPB00142 & 0 & 1 & 3,500 & -- & 3.6 & $75(J)^{c, e}$ & -- & 5,000 & $2.6(\mathrm{~J})^{\mathrm{c}, \mathrm{e}}$ & 2.1 & 3.6 & 5,300 & 4.9 & $2,400(J)^{c, e}$ & 160 & $2.6(\mathrm{~J})^{\dagger}$ & $2,200(J)^{c, e}$ & -- & 210 & $8.6(\mathrm{~J})^{\mathrm{c}, \mathrm{e}}$ & $15(J)^{c, e, t}$ \\
\hline & GPB00143 & 3 & 4 & 7,100 & -- & 7.8 & $88(J)^{c, e}$ & $0.74(J)^{f}$ & 38,000 & $5.5(\mathrm{~J})^{\mathrm{c}, \mathrm{e}}$ & 3.7 & 5.5 & 9,000 & 6.4 & $4,200(J)^{c, e}$ & 270 & $5.1(\mathrm{~J})^{\dagger}$ & $4,200(J)^{c, e}$ & -- & 2,900 & $17(\mathrm{~J})^{\mathrm{c}, \mathrm{e}}$ & $25(J)^{c, e, t}$ \\
\hline \multirow{3}{*}{$\begin{array}{c}\text { Trench } \\
10-16 \\
\text { Trench 10-6 }\end{array}$} & GPB00144 & 0 & 1 & 4,800 & -- & 3.4 & $83(J)^{c, e}$ & -- & 8,200 & $3.5(\mathrm{~J})^{\mathrm{c}, \mathrm{e}}$ & 2.8 & 4.7 & 6,500 & 5.3 & $3,100(J)^{c, e}$ & 200 & $3.6(\mathrm{~J})^{\dagger}$ & $2,800(J)^{c, e}$ & -- & 210 & $10(\mathrm{~J})^{\mathrm{c}, \mathrm{e}}$ & $18(\mathrm{~J})^{\mathrm{c}, \mathrm{e}, \mathrm{f}}$ \\
\hline & GPB00145 & 3 & 4 & 6,900 & -- & 7.2 & $89(J)^{c, e}$ & $0.72(\mathrm{~J})^{\mathrm{f}}$ & 39,000 & $5.3(\mathrm{~J})^{\mathrm{c}, \mathrm{e}}$ & 3.7 & 5.5 & 8,600 & 6.3 & $4,300(\mathrm{~J})^{\mathrm{ce}, \mathrm{e}}$ & 260 & $5.1(J)^{t}$ & $4,400(J)^{c, e}$ & -- & 2,500 & $16(\mathrm{~J})^{c, e}$ & $25(J)^{c, e, t}$ \\
\hline & GPB00146 & 3 & 4 & 7,300 & -- & 8.1 & $100(J)^{c, e}$ & $0.77(\mathrm{~J})^{\dagger}$ & 27,000 & $5.7(\mathrm{~J})^{\mathrm{c}, \mathrm{e}}$ & 4 & 6.1 & 9,400 & 6.8 & $4,300(J)^{c, e}$ & 310 & $5.4(\mathrm{~J})^{\dagger}$ & $3,900\left(J J^{c, e}\right.$ & -- & 2,700 & $18(J)^{c, e}$ & $27(J)^{c, e, f}$ \\
\hline Trench 6-6 & GPB00147 & 5 & 6 & 6,800 & -- & 6.7 & $95\left(J J^{c, e}\right.$ & $0.72(\mathrm{~J})^{\mathrm{f}}$ & 21,000 & $5.4(J)^{c, e}$ & 3.7 & 5.6 & 8,900 & 6.6 & $3,900(\mathrm{~J} J \mathrm{c}, \mathrm{e}$ & 280 & $5.2(\mathrm{~J})^{4}$ & $3,300\left(J J^{c, e}\right.$ & $-\cdot$ & 2,700 & $18\left(\mathrm{~J} \mathrm{~J}^{\mathrm{c}, \mathrm{e}}\right.$ & $26(J)^{c, e, t}$ \\
\hline \multicolumn{23}{|c|}{ Sandia Surface Yard (CAS 03-58-001-03FN) } \\
\hline \multirow{2}{*}{ B1 } & SSY00101 & 0 & 1 & -- & -- & $4.3(\mathrm{~J})^{\mathrm{d}}$ & $93(J)^{d}$ & -- & -- & $4(J)^{d, f}$ & -- & -- & -- & $7.4(\mathrm{~J})^{\mathrm{d}}$ & -- & -- & -- & -- & -- & -- & -- & -- \\
\hline & SSY00101A & 3 & 4 & -- & -- & $4.2(J)^{d}$ & $100(\mathrm{~J})^{\mathrm{d}}$ & -- & -- & $3.6(\mathrm{~J})^{\mathrm{d}, \mathrm{f}}$ & -- & -- & -- & $6.8(\mathrm{~J})^{\mathrm{d}}$ & -- & -- & -- & -- & -- & -- & -- & -- \\
\hline \multirow{2}{*}{ B2 } & SSY00102 & 0 & 1 & -- & -- & $4(J)^{d}$ & $110(J)^{d}$ & -- & -- & $4.2(J)^{d, f f}$ & -- & -- & -- & $40(J)^{d}$ & -- & -- & -- & -- & $0.7(\mathrm{~J})^{d}$ & -- & -- & -- \\
\hline & SSY00102A & 3 & 4 & -- & -- & $3.8(\mathrm{~J})^{\mathrm{d}}$ & $63(J)^{d}$ & -- & -- & $2.6(J)^{d, f}$ & -- & -- & -- & $6.1(J)^{d}$ & -- & -- & -- & -- & -- & -- & -- & -- \\
\hline \multirow{2}{*}{ B3 } & SSY00103 & 0 & 1 & -- & -- & $4.2(J)^{d}$ & $100(J)^{d}$ & -- & -- & $4.6(\mathrm{~J})^{\mathrm{d}, \mathrm{f}}$ & -- & -- & -- & $8.6(\mathrm{~J})^{d}$ & -- & -- & -- & -- & -- & -- & -- & -- \\
\hline & SSY00103A & 3 & 4 & -- & -- & $5.3(\mathrm{~J})^{d}$ & $110(J)^{d}$ & -- & -- & $4.8(J)^{d, f}$ & -- & -- & -- & $8.5(J)^{d}$ & -- & -- & -- & -- & -- & -- & -- & -- \\
\hline \multirow{2}{*}{ B4 } & SSY00104 & 0 & 1 & -- & -- & $4.5(J)^{d}$ & $100(\mathrm{~J})^{\mathrm{d}}$ & -- & -- & $5.1(\mathrm{~J})^{\mathrm{d}, \mathrm{f}}$ & -- & -- & -- & $8.2(\mathrm{~J})^{d}$ & -- & -- & -- & -- & -- & -- & -- & -- \\
\hline & SSY00104A & 3 & 4 & -- & -- & $4.2(J)^{d}$ & $350(J)^{d}$ & -- & -- & $3(\mathrm{~J})^{\mathrm{d}, \mathrm{f}}$ & -- & -- & -- & $19(J)^{d}$ & -- & -- & $-\cdot$ & -- & $0.86(J)^{d}$ & -- & -- & -- \\
\hline \multirow{2}{*}{ B5 } & SSY00105 & 0 & 1 & -- & -- & $5(J)^{d}$ & $88(J)^{d}$ & -- & -- & $3.8(\mathrm{~J})^{\mathrm{d}, \mathrm{f}}$ & -- & -- & -- & $7.6(\mathrm{~J})^{d}$ & -- & -- & -- & -- & -- & -- & -- & -- \\
\hline & SSY00105A & 3 & 4 & -- & -- & $3.6(J)^{d}$ & $69(J)^{d}$ & -- & -- & $2.4(J)^{d, f}$ & -- & -- & -- & $5.2(\mathrm{~J})^{d}$ & -- & -- & -- & -- & -- & -- & -- & -- \\
\hline \multirow{2}{*}{ B6 } & SSY00106 & 0 & 1 & -- & -- & $5.5(J)^{d}$ & $76(J)^{d}$ & -- & -- & $3.5(\mathrm{~J}))^{\mathrm{d}, \mathrm{f}}$ & -- & -- & -- & $33(J)^{d}$ & -- & -- & -- & -- & $0.58(\mathrm{~J})^{\mathrm{d}}$ & -- & -- & -- \\
\hline & SSY00106A & 3 & 4 & -- & -- & $4.7(J)^{d}$ & $100(\mathrm{~J})^{\mathrm{d}}$ & -- & -- & $4.7(J)^{d, f}$ & -- & -- & -- & $7.4(\mathrm{~J})^{d}$ & -- & -- & -- & -- & $0.54(\mathrm{~J})^{\mathrm{d}}$ & -- & -- & -- \\
\hline \multirow{2}{*}{ B7 } & SSY00107 & 0 & 1 & -- & -- & $4.9(\mathrm{~J})^{\mathrm{d}}$ & $100(\mathrm{~J})^{d}$ & -- & -- & $3.4(J)^{d, f}$ & -- & -- & -- & $7.7(\mathrm{~J})^{\mathrm{d}}$ & -- & -- & -- & -- & -- & -- & -- & -- \\
\hline & SSY00107A & 3 & 4 & -- & -- & $4(\mathrm{~J})^{\mathrm{d}}$ & $100(J)^{d}$ & -- & -- & $3.7(\mathrm{~J})^{\mathrm{d}, \mathrm{f}}$ & -- & -- & -- & $6.1(\mathrm{~J})^{d}$ & -- & -- & -- & -- & -- & -- & -- & -- \\
\hline \multirow{2}{*}{ B8 } & SSY00108 & 0 & 1 & -- & -- & $3.2(\mathrm{~J})^{\mathrm{d}}$ & $61(J)^{d}$ & -- & -- & $4.2(J)^{d, f}$ & -- & -- & -- & $6.4(\mathrm{~J})^{\mathrm{d}}$ & -- & -- & -- & -- & -- & -- & -- & -- \\
\hline & SSY00108A & 3 & 4 & -- & -- & $4.6(\mathrm{~J})^{\mathrm{d}}$ & $94(J)^{d}$ & -- & -- & $3.9(\mathrm{~J})^{\mathrm{d}}$ & -- & -- & -- & $8.1(\mathrm{~J})^{d}$ & -- & -- & -- & -- & $0.56(\mathrm{~J})^{\mathrm{d}}$ & -- & -- & -- \\
\hline \multirow{2}{*}{ R1 } & SSY00109 & 0 & 1 & -- & -- & $5.1(\mathrm{~J})^{d}$ & $120(J)^{d}$ & -- & -- & $6.1(\mathrm{~J})^{d}$ & -- & -- & -- & $11(J)^{d}$ & -- & -- & -- & -- & -- & -- & -- & -- \\
\hline & SSY00109A & 3 & 4 & -- & -- & $5.5(J)^{d}$ & $58(J)^{d}$ & -- & -- & $2.8(J)^{\mathrm{d}}$ & -- & -- & -- & $6.2(J)^{d}$ & -- & -- & -- & -- & -- & -- & -- & -- \\
\hline \multirow{3}{*}{ R2 } & SSY00110 & 0 & 1 & -- & -- & $5.2(J)^{d}$ & $120(J)^{d}$ & -- & $-\cdot$ & $5.4(\mathrm{~J})^{d}$ & -- & -- & -- & $11(J)^{d}$ & -- & -- & $-\cdot$ & -- & $0.62(J)^{d}$ & -- & -- & -- \\
\hline & SSY00110A & 3 & 4 & -- & -- & $6.7(J)^{d}$ & $89(J)^{d}$ & -- & -- & $4.9(\mathrm{~J})^{d}$ & -- & -- & -- & $11(J)^{d}$ & $-\cdot$ & -- & -- & -- & $0.68(\mathrm{~J})^{\mathrm{d}}$ & -- & -- & -- \\
\hline & SSY00110B & 3 & 4 & -- & -- & $7.3(J)^{d}$ & $110(\mathrm{~J})^{d}$ & -- & -- & $5(J)^{d}$ & -- & -- & -- & $10(J)^{d}$ & -- & -- & -- & -- & $0.64(\mathrm{~J})^{\mathrm{d}}$ & -- & -- & -- \\
\hline \multirow{2}{*}{ R3 } & SSY00111 & 0 & 1 & -- & -- & $4.6(\mathrm{~J})^{d}$ & $130(\mathrm{~J})^{d}$ & -- & -- & $4.4(\mathrm{~J})^{d}$ & -- & -- & -- & $8.7(\mathrm{~J})^{d}$ & -- & -- & -- & -- & $0.69(\mathrm{~J})^{\mathrm{d}}$ & -- & -- & -- \\
\hline & SSY00111A & 3 & 4 & -- & -- & $4.6(\mathrm{~J})^{\mathrm{d}}$ & $96(J)^{d}$ & -- & -- & $3.5(\mathrm{~J})^{d}$ & -- & -- & -- & $6.4(\mathrm{~J})^{d}$ & -- & -- & -- & -- & -- & -- & -- & -- \\
\hline
\end{tabular}


Table A.3-5

Soil Sample Results for Total RCRA Metals Detected Above Minimum Reporting Limits, CAU 490, Station 44 Burn Area

(Sheet 4 of 5)

\begin{tabular}{|c|c|c|c|c|c|c|c|c|c|c|c|c|c|c|c|c|c|c|c|c|c|c|}
\hline \multirow[b]{2}{*}{$\begin{array}{l}\text { Sample } \\
\text { Location }\end{array}$} & \multirow[b]{2}{*}{$\begin{array}{l}\text { Sample } \\
\text { Number }\end{array}$} & \multirow[b]{2}{*}{$\begin{array}{c}\text { Start } \\
\text { Depth } \\
\text { (ft) }\end{array}$} & \multirow[b]{2}{*}{$\begin{array}{c}\text { End } \\
\text { Depth } \\
\text { (ft) }\end{array}$} & \multicolumn{19}{|c|}{ Contaminants of Potential Concern $(\mathrm{mg} / \mathrm{kg})$} \\
\hline & & & & 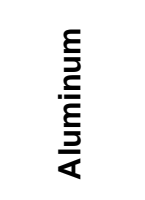 & 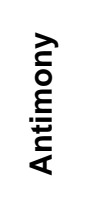 & 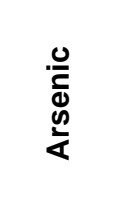 & 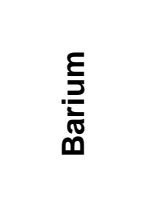 & 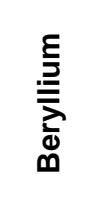 & $\frac{\xi}{\frac{\Xi}{0}}$ & 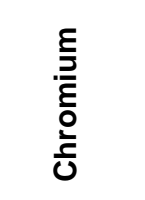 & 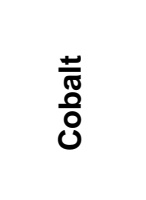 & $\begin{array}{l}\text { ¿े } \\
\text { 응 }\end{array}$ & $\stackrel{\check{\sigma}}{\underline{\underline{o}}}$ & $\stackrel{\square}{\Xi ّ}$ & 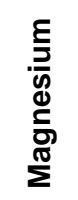 & 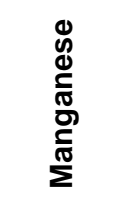 & 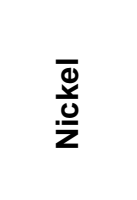 & 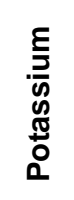 & 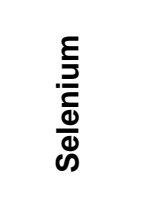 & 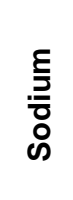 & 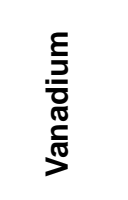 & $\stackrel{0}{\stackrel{N}{N}}$ \\
\hline \multicolumn{4}{|c|}{ Preliminary Action Levels ${ }^{\mathbf{a}}$} & 100,000 & 820 & 2.7 & 100,000 & 2,200 & $\mathrm{NI}$ & 450 & 100,000 & 76,000 & 100,000 & 1,000 & $\mathrm{NI}$ & 32,000 & 41,000 & $\mathrm{NI}$ & 10,000 & $\mathbf{N I}$ & 14,000 & 100,000 \\
\hline \multicolumn{23}{|c|}{ Sandia Surface Yard (CAS 03-58-001-03FN) } \\
\hline \multirow{2}{*}{ R4 } & SSY00112 & 0 & 1 & -- & -- & $4.3(\mathrm{~J})^{\mathrm{d}}$ & $100(J)^{d}$ & -- & -- & $4.2(\mathrm{~J})^{d}$ & -- & -- & -- & $9.4(\mathrm{~J})^{\mathrm{d}}$ & -- & -- & -- & -- & -- & -- & -- & -- \\
\hline & SSY00112A & 3 & 4 & -- & -- & $6.2(\mathrm{~J})^{d}$ & $130(\mathrm{~J})^{d}$ & -- & -- & $5(J)^{d}$ & -- & -- & -- & $10(J)^{d}$ & -- & -- & -- & -- & -- & -- & -- & -- \\
\hline \multirow{2}{*}{ R5 } & SSY00113 & 0 & 1 & -- & -- & $4.7(\mathrm{~J})^{\mathrm{d}}$ & $110(\mathrm{~J})^{d}$ & -- & -- & $7.3(\mathrm{~J})^{d}$ & -- & -- & -- & $8.8(\mathrm{~J})^{\mathrm{d}}$ & -- & -- & -- & - & -- & -- & -- & -- \\
\hline & SSY00113A & 3 & 4 & -- & -- & $4(J)^{d}$ & $80(J)^{d}$ & -- & -- & $3.6(\mathrm{~J})^{d}$ & -- & -- & -- & $7.5(J)^{d}$ & -- & -- & -- & -- & -- & -- & -- & -- \\
\hline \multirow{2}{*}{ R6 } & SSY00114 & 0 & 1 & -- & -- & $4.2(\mathrm{~J})^{\mathrm{d}}$ & $84(J)^{d}$ & -- & -- & $3.7(\mathrm{~J})^{\mathrm{d}}$ & -- & -- & -- & $8.1(\mathrm{~J})^{\mathrm{d}}$ & -- & -- & -- & -- & -- & -- & -- & -- \\
\hline & SSY00114A & 3 & 4 & -- & -- & $3.9(J)^{d}$ & $93(J)^{d}$ & -- & -- & $2.6(\mathrm{~J})^{d}$ & -- & -- & -- & $6.4(\mathrm{~J})^{d}$ & -- & -- & -- & -- & $-\cdot$ & -- & -- & -- \\
\hline \multirow{2}{*}{ R7 } & SSY00115 & 0 & 1 & -- & -- & $4.4(\mathrm{~J})^{\mathrm{d}}$ & $100(J)^{d}$ & -- & -- & $6.2(\mathrm{~J})^{d}$ & -- & -- & -- & $9.6(\mathrm{~J})^{\mathrm{d}}$ & -- & -- & -- & -- & -- & -- & -- & -- \\
\hline & SSY00115A & 3 & 4 & -- & -- & $5.9(\mathrm{~J})^{\mathrm{d}}$ & $59(J)^{d}$ & -- & -- & $3.2(J)^{d}$ & -- & -- & -- & $6.7(J)^{d}$ & -- & -- & -- & -- & -- & -- & -- & -- \\
\hline \multirow{2}{*}{ R8 } & SSY00116 & 0 & 1 & -- & -- & $5(J)^{d}$ & $120(J)^{d}$ & -- & -- & $5.1(\mathrm{~J})^{d}$ & -- & -- & -- & $10(J)^{d}$ & -- & -- & -- & -- & $0.97(\mathrm{~J})^{\mathrm{d}}$ & -- & -- & -- \\
\hline & SSY00116A & 3 & 4 & -- & -- & $5(J)^{d}$ & $91(J)^{d}$ & -- & -- & $4.2(J)^{d}$ & -- & -- & -- & $7.1(\mathrm{~J})^{\mathrm{d}}$ & -- & -- & -- & -- & $0.54(\mathrm{~J})^{\mathrm{d}}$ & -- & -- & -- \\
\hline \multirow{2}{*}{ R9 } & SSY00117 & 0 & 1 & -- & -- & $4.4(\mathrm{~J})^{\mathrm{d}}$ & $140(J)^{d}$ & -- & -- & $4(J)^{d}$ & -- & -- & -- & $9.1(J)^{d}$ & -- & -- & -- & -- & $0.57(\mathrm{~J})^{\mathrm{d}}$ & -- & -- & -- \\
\hline & SSY00117A & 3 & 4 & -- & -- & $4.8(\mathrm{~J})^{\mathrm{d}}$ & $96(J)^{d}$ & -- & -- & $3.9(\mathrm{~J})^{d}$ & -- & -- & -- & $7.4(\mathrm{~J})^{\mathrm{d}}$ & -- & -- & -- & -- & -- & -- & -- & -- \\
\hline \multirow{2}{*}{ R10 } & SSY00118 & 0 & 1 & -- & -- & $4.6(\mathrm{~J})^{\mathrm{d}}$ & $110(J)^{d}$ & -- & -- & $5(J)^{d}$ & -- & -- & -- & $10(J)^{d}$ & -- & -- & -- & -- & $0.58(\mathrm{~J})^{\mathrm{d}}$ & -- & -- & -- \\
\hline & SSY00118A & 3 & 4 & -- & -- & $5.3(\mathrm{~J})^{\mathrm{d}}$ & $98(J)^{d}$ & -- & -- & $3.9(\mathrm{~J})^{d}$ & -- & -- & -- & $7.4(\mathrm{~J})^{\mathrm{d}}$ & -- & -- & -- & -- & $0.62(J)^{d}$ & -- & -- & -- \\
\hline \multirow{2}{*}{ R11 } & SSY00119 & 0 & 1 & -- & -- & $4.7(\mathrm{~J})^{\mathrm{d}}$ & $97(J)^{d}$ & -- & -- & $5(J)^{d}$ & -- & -- & -- & $8.6(\mathrm{~J})^{d}$ &.- & -- & -- & -- & -- & -- & -- & -- \\
\hline & SSY00119A & 3 & 4 & -- & -- & $3.7(\mathrm{~J})^{b}$ & $110(J)^{d}$ & -- & -- & $2.5(\mathrm{~J})^{\mathrm{d}}$ & -- & -- & -- & $8.9(\mathrm{~J})^{\mathrm{d}}$ & -- & -- & -- & -- & -- & -- & -- & -- \\
\hline \multirow{3}{*}{$\mathrm{R} 12$} & SSY00120 & 0 & 1 & -- & -- & $4.3(J)^{d}$ & $96(J)^{d}$ & -- & -- & $3.4(\mathrm{~J})^{d}$ & -- & -- & -- & $9.8(\mathrm{~J})^{d}$ & -- & -- & -- & -- & $0.57(\mathrm{~J})^{\mathrm{d}}$ & -- & -- & -- \\
\hline & SSY00120A & 3 & 4 & -- & -- & $4.3(J)^{d}$ & $85(J)^{d}$ & -- & -- & $3.5(\mathrm{~J})^{\mathrm{d}}$ & -- & -- & -- & $6.7(\mathrm{~J})^{\mathrm{d}}$ & -- & -- & -- & -- & -- & -- & -- & -- \\
\hline & SSY00120B & 3 & 4 & -- & -- & $5.1(\mathrm{~J})^{d}$ & $75(J)^{d}$ & -- & -- & $3.2(\mathrm{~J})^{d}$ & -- & -- & -- & $6.6(\mathrm{~J})^{\mathrm{d}}$ & -- & -- & -- & -- & $0.59(J)^{d}$ & -- & -- & -- \\
\hline \multirow{2}{*}{ R13 } & SSY00121 & 0 & 1 & -- & -- & $4.7(J)^{d}$ & $100(J)^{d}$ & -- & -- & $4.5(\mathrm{~J})^{\mathrm{d}}$ & -- & -- & -- & $9.1(\mathrm{~J})^{d}$ & $-\cdot$ & -- & -- & -- & -- & $-\cdot$ & -- & -- \\
\hline & SSY00121A & 3 & 4 & -- & -- & $5.8(\mathrm{~J})^{\mathrm{d}}$ & $79(\mathrm{~J})^{d}$ & -- & -- & $3.8(\mathrm{~J})^{\mathrm{d}}$ & -- & -- & -- & $7.6(J)^{d}$ & -- & -- & -- & -- & -- & -- & -- & -- \\
\hline \multirow{2}{*}{ R14 } & SSY00122 & 0 & 1 & -- & -- & $4.7(J)^{d}$ & $92(J)^{d}$ & -- & -- & $4.7(\mathrm{~J})^{d}$ & -- & -- & -- & $10(J)^{d}$ & -- & -- & -- & -- & $0.56(\mathrm{~J})^{\mathrm{d}}$ & -- & -- & -- \\
\hline & SSY00122A & 3 & 4 & -- & -- & $5.2(J)^{d}$ & $97(J)^{d}$ & -- & -- & $4.3(\mathrm{~J})^{\mathrm{d}}$ & -- & -- & -- & $7.9(\mathrm{~J})^{\mathrm{d}}$ & -- & -- & -- & -- & -- & -- & -- & -- \\
\hline \multirow{2}{*}{ R15 } & SSY00123 & 0 & 1 & -- & -- & $4.7(\mathrm{~J})^{\mathrm{d}}$ & $95(J)^{d}$ & -- & -- & $4(J)^{d}$ & -- & -- & -- & $9.3(\mathrm{~J})^{d}$ & -- & -- & -- & -- & $-\cdot$ & -- & -- & -- \\
\hline & SSY00123A & 3 & 4 & -- & -- & $5.5(\mathrm{~J})^{d}$ & $75(J)^{d}$ & -- & -- & $2.8(\mathrm{~J})^{\mathrm{d}}$ & -- & -- & -- & $7.8(\mathrm{~J})^{\mathrm{d}}$ & -- & -- & -- & -- & -- & -- & -- & -- \\
\hline \multirow{2}{*}{ B650 } & SSY00124 & 0 & 1 & -- & -- & $4.2(J)^{d}$ & $71(J)^{d}$ & -- & -- & $3.3(\mathrm{~J})^{d}$ & -- & -- & -- & $6.6(\mathrm{~J})^{d}$ & -- & -- & -- & -- & -- & -- & -- & -- \\
\hline & SSY00124A & 3 & 4 & -- & -- & $4.9(\mathrm{~J})^{\mathrm{d}}$ & $91(J)^{d}$ & -- & -- & $4.3(\mathrm{~J})^{d}$ & -- & -- & -- & $8.2(\mathrm{~J})^{\mathrm{d}}$ & -- & -- & -- & -- & $0.54(J)^{d}$ & -- & -- & -- \\
\hline \multirow{2}{*}{ B1250 } & SSY00125 & 0 & 1 & -- & -- & $4.3(\mathrm{~J})^{\mathrm{d}}$ & $100(J)^{d}$ & -- & -- & $3.8(\mathrm{~J})^{\mathrm{d}}$ & -- & -- & -- & $11(J)^{d}$ & -- & -- & -- & -- & -- & -- & -- & -- \\
\hline & SSY00125A & 3 & 4 & -- & -- & $5.3(\mathrm{~J})^{\mathrm{d}}$ & $83(\mathrm{~J})^{\mathrm{d}}$ & -- & -- & $3.6(\mathrm{~J})^{d}$ & -- & -- & -- & $6.3(\mathrm{~J})^{\mathrm{d}}$ & -- & -- & -- & -- & -- & -- & -- & -- \\
\hline
\end{tabular}


Table A.3-5

\begin{tabular}{|c|c|c|c|c|c|c|c|c|c|c|c|c|c|c|c|c|c|c|c|c|c|c|}
\hline \multirow[b]{2}{*}{$\begin{array}{l}\text { Sample } \\
\text { Location }\end{array}$} & \multirow[b]{2}{*}{$\begin{array}{l}\text { Sample } \\
\text { Number }\end{array}$} & \multirow[b]{2}{*}{$\begin{array}{c}\text { Start } \\
\text { Depth } \\
\text { (ft) }\end{array}$} & \multirow[b]{2}{*}{$\begin{array}{c}\text { End } \\
\text { Depth } \\
\text { (ft) }\end{array}$} & \multicolumn{19}{|c|}{ Contaminants of Potential Concern $(\mathrm{mg} / \mathrm{kg})$} \\
\hline & & & & $\begin{array}{l}\underline{E} \\
\underline{\underline{\underline{E}}} \\
\frac{\underline{\underline{E}}}{\alpha}\end{array}$ & 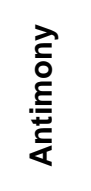 & 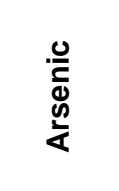 & 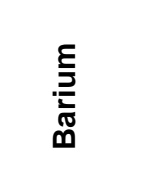 & 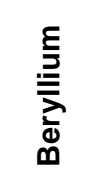 & $\frac{\xi}{\frac{E}{0}}$ & 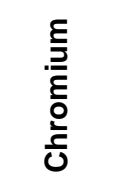 & 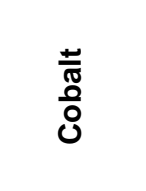 & 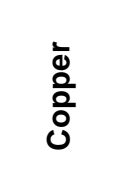 & $\underline{\underline{\underline{o}}}$ & $\stackrel{\Xi}{\Xi}$ & $\begin{array}{l}\underline{\Xi} \\
\bar{\Phi} \\
\bar{\Phi} \\
\bar{g} \\
\Sigma\end{array}$ & 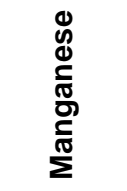 & $\begin{array}{l}\bar{\Phi} \\
\stackrel{\bar{\Xi}}{z} \\
\end{array}$ & $\begin{array}{l}\frac{E}{\bar{g}} \\
\bar{d} \\
\frac{\mathrm{J}}{0} \\
0\end{array}$ & 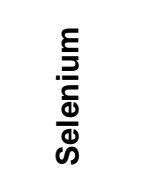 & $\begin{array}{l}\underline{\xi} \\
\text { 흥 } \\
\text { c }\end{array}$ & 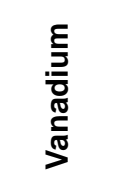 & $\stackrel{0}{\stackrel{5}{N}}$ \\
\hline \multicolumn{4}{|c|}{ Preliminary Action Levels ${ }^{a}$} & 100,000 & 820 & 2.7 & 100,000 & 2,200 & NI & 450 & 100,000 & 76,000 & 100,000 & 1,000 & NI & 32,000 & 41,000 & NI & 10,000 & NI & 14,000 & 100,000 \\
\hline \multicolumn{23}{|c|}{ Sandia Surface Yard (CAS 03-58-001-03FN) } \\
\hline \multirow{3}{*}{ B850 } & SSY00126 & 0 & 1 & -- & -- & $4.4(\mathrm{~J})^{\mathrm{d}}$ & $100(J)^{d}$ & -- & -- & $4.1(\mathrm{~J})^{d}$ & -- & -- & -- & $10(J)^{d}$ & -- & -- & -- & -- & -- & -- & -- & -- \\
\hline & SSY00126A & 3 & 4 & -- & -- & $3.9(\mathrm{~J})^{\mathrm{d}}$ & $94(J)^{d}$ & -- & -- & $2.2(\mathrm{~J})^{\mathrm{d}}$ & -- & -- & -- & $7.7(\mathrm{~J})^{\mathrm{d}}$ & -- & -- & -- & -- & $0.68(J)^{d}$ & -- & -- & -- \\
\hline & SSY00126B & 3 & 4 & -- & -- & $5(J)^{d}$ & $110(J)^{d}$ & -- & -- & $3.1(\mathrm{~J})^{d}$ & -- & -- & -- & $7(\mathrm{~J})^{\mathrm{d}}$ & -- & -- & -- & -- & $0.59(J)^{d}$ & -- & -- & -- \\
\hline \multicolumn{23}{|c|}{ Station 44 Burn Area (CAS RG-56-001-RGBA) } \\
\hline \multirow{2}{*}{ Station 1} & ST44SB001 & 0 & 1 & -- & -- & $4.5(\mathrm{~J})^{\mathrm{d}}$ & $80(\mathrm{~J})^{\mathrm{d}}$ & -- & -- & $6.6(\mathrm{~J})^{d}$ & -- & -- & -- & $8.4(\mathrm{~J})^{\mathrm{d}}$ & -- & -- & -- & -- & -- & -- & -- & $29(J)^{d}$ \\
\hline & ST44SB002 & 3 & 4 & -- & -- & $5.1(\mathrm{~J})^{\mathrm{d}}$ & $37(J)^{d}$ & -- & -- & $3.5(\mathrm{~J})^{\mathrm{d}}$ & -- & -- & -- & $3.7(\mathrm{~J})^{\mathrm{d}}$ & -- & -- & -- & -- & -- & -- & -- & $14(J)^{d}$ \\
\hline \multirow{2}{*}{ Station 2} & ST44SB003 & 0 & 1 & -- & -- & $5.2(\mathrm{~J})^{\mathrm{d}}$ & $79(\mathrm{~J})^{\mathrm{d}}$ & -- & -- & $5.4(\mathrm{~J})^{\mathrm{d}}$ & -- & -- & -- & $7.3(\mathrm{~J})^{\mathrm{d}}$ & -- & -- & -- & $-\cdot$ & -- & -- & -- & $24(J)^{d}$ \\
\hline & ST44SB004 & 3 & 4 & -- & -- & $5.6(\mathrm{~J})^{\mathrm{d}}$ & $40(J)^{d}$ & -- & -- & $3.6(\mathrm{~J})^{\mathrm{d}}$ & -- & -- & -- & $3.7(\mathrm{~J})^{\mathrm{d}}$ & -- & -- & -- & -- & -- & -- & -- & $17(J)^{d}$ \\
\hline \multirow{2}{*}{ Station 3} & ST44SB005 & 0 & 1 & -- & -- & $3.7(\mathrm{~J})^{\mathrm{d}}$ & $74(J)^{d}$ & - & $-\cdot$ & $3.7(\mathrm{~J})^{d}$ & - & -- & - & $5.5(\mathrm{~J})^{\mathrm{d}}$ & -- & -- & $-\cdot$ & -- & $-\cdot$ & - & - & $19(J)^{d}$ \\
\hline & ST44SB006 & 3 & 4 & -- & -- & $7(J)^{d}$ & $81(J)^{d}$ & -- & -- & $4.7(\mathrm{~J})^{d}$ & -- & -- & -- & $5.2(\mathrm{~J})^{\mathrm{d}}$ & -- & -- & -- & -- & -- & -- & -- & $22(J)^{d}$ \\
\hline \multirow{2}{*}{ Station 4} & ST44SB007 & 0 & 1 & -- & -- & $4.2(\mathrm{~J})^{\mathrm{d}}$ & $73(\mathrm{~J})^{d}$ & -- & -- & $4.1(\mathrm{~J})^{\mathrm{d}}$ & -- & -- & -- & $5.8(\mathrm{~J})^{d}$ & -- & -- & -- & -- & -- & -- & -- & $20(\mathrm{~J})^{\mathrm{d}}$ \\
\hline & ST44SB008 & 3 & 4 & -- & -- & $7.5(\mathrm{~J})^{\mathrm{d}}$ & $77(\mathrm{~J})^{\mathrm{d}}$ & -- & -- & $5.2(\mathrm{~J})^{\mathrm{d}}$ & -- & -- & -- & $6.2(\mathrm{~J})^{\mathrm{d}}$ & -- & -- & -- & -- & -- & -- & -- & $25(J)^{d}$ \\
\hline
\end{tabular}

${ }^{a}$ Environmental Protection Agency Region 9 Industrial Preliminary Remediation Goals (PRGs) (EPA, 1998)

${ }^{b}$ Duplicate precision analyses were outside control limits

${ }^{C}$ Predigestion/post-digestion matrix spike recovery criteria not met

${ }^{d}$ Serial dilution \%D was outside control limits

eSample shipping temperature exceeded

${ }^{f}$ ICP serial dilution recovery was not met

$\mathrm{J}=$ Estimated value

$\mathrm{mg} / \mathrm{kg}=$ Milligrams per kilogram

$\mathrm{ft}=$ Foot (Feet)
$\mathrm{Nl}=$ Not Indicated

$\mathrm{NI}=$ Not Indicated

minimum reporting limit 


\section{A.3.6 Total PCB Results}

The PCB analysis was only performed at SSY. Soil sample results for PCBs did not exceed minimum reporting limits (DOE/NV, 2000).

\section{A.3.7 Gamma Spectrometry}

Gamma spectrometry was not performed at GPBA. The gamma spectrometry results from FTA, SSY, and STA44 detected in soil above the minimum reporting limits as specified in the CAIP (DOE/NV, 2000) are presented in Table A.3-6. This analysis was run for waste management purposes only. The radiological results were not distinguishable from background concentrations listed in the Off-Site Radiation Exposure Review Project (McArthur and Miller, 1989) or the Environmental Monitoring Report for the Proposed Ward Valley, California, Low-Level Radioactive Waste (LLRW) Facility (Atlan-Tech, 1992).

\section{A.3.8 Isotopic Uranium Results}

Isotopic uranium analysis was not performed at FTA, SSY, and STA44. Uranium results for soil samples from GPBA detected above the minimum reporting limit (DOE/NV, 2000) are presented in Table A.3-7. The radiological results were not distinguishable from background concentrations listed in the Off-Site Radiation Exposure Review Project, Phase II Soils Program (McArthur and Miller, 1989), or the Environmental Monitoring Report for the Proposed Ward Valley, California, Low-Level Radioactive Waste (LLRW) Facility (Atlan-Tech, 1992), and therefore do not exceed PALs (DOE/NV, 2000).

\section{A.3.9 Explosives}

Explosive analysis was not performed at FTA, SSY, and STA44. The explosives results for soil samples collected at GPBA detected above the minimum reporting limits (DOE/NV, 2000) are presented in Table A.3-8. None of the soil results from GPBA exceed the PALs as established in the CAIP (DOE/NV, 2000). 
Table A.3-6

Soil Sample Results for Gamma-Emitting Radionuclides Above MRLs, CAU 490, Station 44 Burn Area

(Page 1 of 3 )

\begin{tabular}{|c|c|c|c|c|c|c|c|c|c|c|c|c|}
\hline \multirow[b]{2}{*}{$\begin{array}{l}\text { Sample } \\
\text { Location }\end{array}$} & \multirow[b]{2}{*}{$\begin{array}{l}\text { Sample } \\
\text { Number }\end{array}$} & \multirow[b]{2}{*}{ 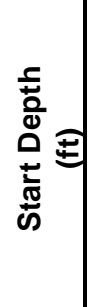 } & \multirow[b]{2}{*}{$\begin{array}{l}\text { 옹 } \\
\text { 옹 } \\
\text { 을 }\end{array}$} & \multicolumn{9}{|c|}{ Contaminants of Potential Concern (pCi/g) } \\
\hline & & & & 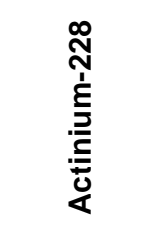 & 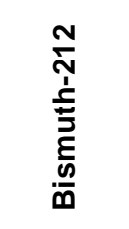 & 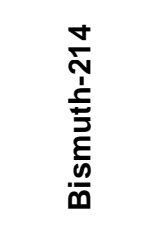 & 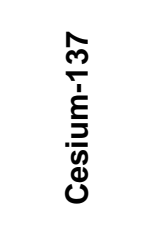 & 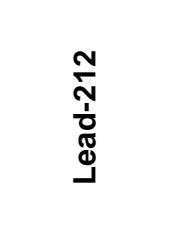 & 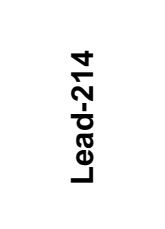 & 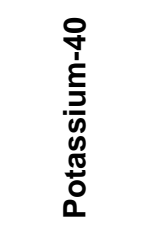 & 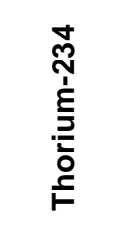 & 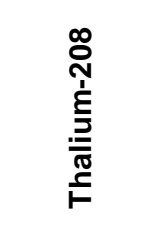 \\
\hline \multicolumn{4}{|c|}{ Preliminary Action Levels ${ }^{a, b}$} & $3.65^{\mathrm{a}}$ & $2.4^{\mathrm{b}}$ & $3.47^{b}$ & $7^{\mathrm{b}}$ & $2.9^{\mathrm{a}}$ & $2.9^{b}$ & $96^{\mathrm{a}}$ & $3.2^{\mathrm{b}}$ & $3.4^{\mathrm{a}}$ \\
\hline \multirow{2}{*}{ Station 1} & ST44SB001 & 0 & 1 & $2.29 \pm 0.64$ & $2.3 \pm 1.1$ & $1.83 \pm 0.39$ & -- & $2.25 \pm 0.37$ & $1.7 \pm 0.41$ & $36.7 \pm 5.7$ & -- & $0.69 \pm 0.22$ \\
\hline & ST44SB002 & 3 & 4 & $2.62 \pm 0.79$ & -- & $2.03 \pm 0.55$ & -- & $1.74 \pm 0.35$ & $1.51 \pm 0.39$ & $30.9 \pm 5.6$ & -- & $0.63 \pm 0.29$ \\
\hline \multirow{2}{*}{ Station 2} & ST44SB003 & 0 & 1 & $2.28 \pm 0.68$ & -- & $2.12 \pm 0.62$ & -- & $1.87 \pm 0.37$ & $1.87 \pm 0.56$ & $30.4 \pm 6.0$ & -- & $0.9 \pm 0.38$ \\
\hline & ST44SB004 & 3 & 4 & $2.97 \pm 0.76$ & -- & $1.89 \pm 0.81$ & -- & $2.72 \pm 0.64$ & $1.77 \pm 0.45$ & $26.6 \pm 5.3$ & -- & $0.8 \pm 0.34$ \\
\hline \multirow{2}{*}{ Station 3} & ST44SB005 & 0 & 1 & $2.61 \pm 0.71$ & -- & $1.84 \pm 0.38$ & -- & $2.04 \pm 0.33$ & $1.37 \pm 0.27$ & $33.3 \pm 5.0$ & -- & $0.65 \pm 0.20$ \\
\hline & ST44SB006 & 3 & 4 & $2.61 \pm 0.71$ & -- & $2.36 \pm 0.55$ & -- & $2.23 \pm 0.52$ & $2.19 \pm 0.55$ & $25.5 \pm 4.9$ & -- & $0.7 \pm 0.28$ \\
\hline \multirow{4}{*}{ Station 4} & ST44SB007 & 0 & 1 & $3.46 \pm 0.95$ & -- & $1.87 \pm 0.59$ & -- & $2.11 \pm 0.52$ & $1.81 \pm 0.48$ & $32.1 \pm 6.2$ & $6.7 \pm 2.8$ & $0.8 \pm 0.32$ \\
\hline & ST44SB008 & 3 & 4 & $3.41 \pm 0.88$ & -- & $1.92 \pm 0.89$ & -- & $2.42 \pm 0.45$ & $1.86 \pm 0.47$ & $33.7 \pm 6.4$ & -- & $0.93 \pm 0.22$ \\
\hline & ST44SB009 & 0 & 1 & $2.43 \pm 0.80$ & $2.6 \pm 1.2$ & $2.4 \pm 0.68$ & -- & $2.16 \pm 0.34$ & $1.82 \pm 0.45$ & $37.8 \pm 5.5$ & $4.8 \pm 2.4$ & $0.92 \pm 0.27$ \\
\hline & ST44SB010 & 3 & 4 & $2.82 \pm 0.72$ & -- & $2.11 \pm 0.53$ & -- & $2.27 \pm 0.37$ & $2.23 \pm 0.56$ & $34.7 \pm 5.1$ & -- & $0.88 \pm 0.26$ \\
\hline \multirow{2}{*}{ B1 } & SSY00101 & 0 & 1 & $2.66 \pm 0.75$ & -- & $2.04 \pm 0.69$ & -- & $2.45 \pm 0.46$ & $1.82 \pm 0.49$ & $39 \pm 5.9$ & -- & $0.88 \pm 0.31$ \\
\hline & SSY00101A & 3 & 4 & $2.51 \pm 0.61$ & $3.8 \pm 1.2$ & $1.92 \pm 0.64$ & -- & $2.32 \pm 0.51$ & $1.33 \pm 0.43$ & $33.9 \pm 6.3$ & -- & $0.85 \pm 0.29$ \\
\hline \multirow{2}{*}{ B2 } & SSY00102 & 0 & 1 & $2.3 \pm 0.76$ & -- & $1.48 \pm 0.41$ & $0.67 \pm 0.33$ & $2.05 \pm 0.37$ & $1.79 \pm 0.54$ & $33.1 \pm 5.9$ & -- & $0.66 \pm 0.21$ \\
\hline & SSY00102A & 3 & 4 & $2.43 \pm 0.61$ & -- & $1.21 \pm 0.52$ & -- & $1.41 \pm 0.32$ & $1.51 \pm 0.45$ & $37.3 \pm 5.6$ & -- & $0.82 \pm 0.23$ \\
\hline \multirow{2}{*}{ B3 } & SSY00103 & 0 & 1 & $2.94 \pm 0.66$ & -- & $2.21 \pm 0.49$ & -- & $1.42 \pm 0.29$ & $1.74 \pm 0.47$ & $31.7 \pm 5.3$ & -- & $0.6 \pm 0.21$ \\
\hline & SSY00103A & 3 & 4 & $3.08 \pm 0.94$ & -- & $2.41 \pm 0.58$ & -- & $2.06 \pm 0.39$ & $1.72 \pm 0.44$ & $40.4 \pm 7.3$ & -- & $0.85 \pm 0.29$ \\
\hline
\end{tabular}


Table A.3-6

Soil Sample Results for Gamma-Emitting Radionuclides Above MRLs, CAU 490, Station 44 Burn Area

(Page 2 of 3 )

\begin{tabular}{|c|c|c|c|c|c|c|c|c|c|c|c|c|}
\hline \multirow[b]{2}{*}{$\begin{array}{l}\text { Sample } \\
\text { Location }\end{array}$} & \multirow[b]{2}{*}{$\begin{array}{l}\text { Sample } \\
\text { Number }\end{array}$} & \multirow[b]{2}{*}{ 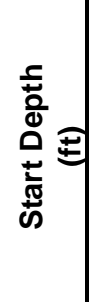 } & \multirow[b]{2}{*}{ 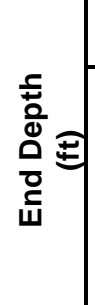 } & \multicolumn{9}{|c|}{ Contaminants of Potential Concern $(\mathrm{pCi} / \mathrm{g})$} \\
\hline & & & & 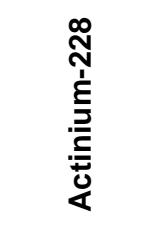 & 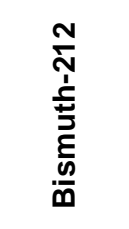 & 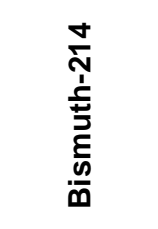 & 浐 & 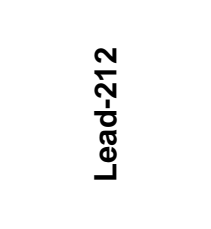 & 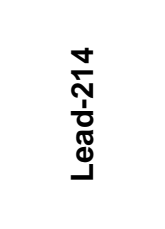 & 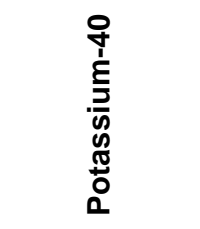 & 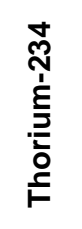 & 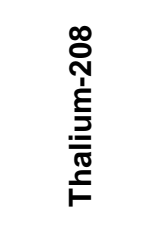 \\
\hline \multicolumn{4}{|c|}{ Preliminary Action Levels ${ }^{a, b}$} & $3.65^{\mathrm{a}}$ & $2.4^{b}$ & $3.47^{b}$ & $7^{\mathrm{b}}$ & $2.9^{\mathrm{a}}$ & $2.9^{b}$ & $96^{\mathrm{a}}$ & $3.2^{\mathrm{b}}$ & $3.4^{\mathrm{a}}$ \\
\hline \multirow{2}{*}{ B4 } & SSY00104 & 0 & 1 & $2.22 \pm 0.63$ & -- & $2.25 \pm 0.88$ & -- & $1.78 \pm 0.36$ & $1.89 \pm 0.59$ & $33.1 \pm 6.1$ & -- & $1.09 \pm 0.34$ \\
\hline & SSY00104A & 3 & 4 & $2.39 \pm 0.66$ & $2.9 \pm 1.4$ & $1.63 \pm 0.59$ & -- & $2.6 \pm 0.77$ & $1.72 \pm 0.38$ & $37.9 \pm 5.8$ & -- & $0.78 \pm 0.17$ \\
\hline \multirow{2}{*}{ B5 } & SSY00105 & 0 & 1 & $2.75 \pm 0.63$ & -- & $2.01 \pm 0.49$ & -- & $1.75 \pm 0.33$ & $1.96 \pm 0.48$ & $32.8 \pm 5.8$ & -- & $0.73 \pm 0.20$ \\
\hline & SSY00105A & 3 & 4 & $2.96 \pm 0.83$ & -- & $2.36 \pm 0.77$ & -- & $1.85 \pm 0.37$ & $2.28 \pm 0.75$ & $34.5 \pm 6.6$ & -- & $1.05 \pm 0.30$ \\
\hline \multirow{3}{*}{$\mathbf{R 2}$} & SSY00110 & 0 & 1 & $2.08 \pm 0.57$ & -- & $1.44 \pm 0.40$ & -- & $1.27 \pm 0.32(\mathrm{~J})^{\mathrm{c}}$ & $1.84 \pm 0.44$ & $35.4 \pm 5.2$ & -- & $0.84 \pm 0.27$ \\
\hline & SSY00110A & 3 & 4 & $3.73 \pm 0.91$ & -- & $1.69 \pm 0.49$ & -- & $2.54 \pm 0.65(\mathrm{~J})^{\mathrm{c}}$ & $1.65 \pm 0.48$ & $30.1 \pm 5.5$ & -- & $0.9 \pm 0.25$ \\
\hline & SSY00110B & 3 & 4 & $3.05 \pm 0.95$ & -- & $2.05 \pm 0.62$ & -- & $2.25 \pm 0.43(\mathrm{~J})^{\mathrm{c}}$ & $1.49 \pm 0.45$ & $35.5 \pm 7.0$ & -- & $0.97 \pm 0.32$ \\
\hline \multirow{3}{*}{ B850 } & SSY00126 & 0 & 1 & $2.64 \pm 0.64$ & -- & $1.73 \pm 0.51$ & -- & $1.17 \pm 0.28$ & $1.56 \pm 0.33$ & $36.4 \pm 5.8$ & -- & $0.6 \pm 0.20$ \\
\hline & SSY00126A & 3 & 4 & $2.3 \pm 0.53$ & -- & $1.89 \pm 0.60$ & -- & $2.58 \pm 0.59$ & $1.62 \pm 0.46$ & $32.6 \pm 5.7$ & -- & $0.98 \pm 0.33$ \\
\hline & SSY00126B & 3 & 4 & $2.96 \pm 0.74$ & -- & $3 \pm 0.62$ & -- & $2.23 \pm 0.54$ & $1.66 \pm 0.58$ & $31.2 \pm 6.2$ & -- & $1.05 \pm 0.36$ \\
\hline \multirow{3}{*}{ R12 } & SSY00120 & 0 & 1 & $3.28 \pm 0.80$ & -- & $1.61 \pm 0.49$ & -- & $2.25 \pm 0.42$ & $1.43 \pm 0.44$ & $35 \pm 6.3(\mathrm{~J})^{\mathrm{c}}$ & -- & $0.86 \pm 0.24$ \\
\hline & SSY00120A & 3 & 4 & $2.18 \pm 0.56$ & -- & $1.59 \pm 0.42$ & -- & $2.68 \pm 0.51$ & $1.31 \pm 0.32$ & $35.8 \pm 5.2(\mathrm{~J})^{\mathrm{c}}$ & -- & $0.7 \pm 0.26$ \\
\hline & SSY00120B & 3 & 4 & $3.46 \pm 0.93$ & -- & $1.49 \pm 0.47$ & -- & $1.75 \pm 0.33$ & $1.37 \pm 0.37$ & $34.3 \pm 5.6(J)^{c}$ & -- & $0.78 \pm 0.21$ \\
\hline E1 & FTA00103 & 9 & 10 & $2.62 \pm 0.79$ & -- & $1.75 \pm 0.56$ & -- & $2.04 \pm 0.41$ & $1.98 \pm 0.61$ & $28.4 \pm 5.8$ & -- & $1.19 \pm 0.31$ \\
\hline E6 & FTA00109 & 0 & 1 & $2.71 \pm 0.90$ & -- & $1.85 \pm 0.54$ & -- & $2.33 \pm 0.42$ & $1.96 \pm 0.46$ & $37.2 \pm 5.7$ & -- & $0.71 \pm 0.23$ \\
\hline
\end{tabular}


Table A.3-6

Soil Sample Results for Gamma-Emitting Radionuclides Above MRLs, CAU 490, Station 44 Burn Area (Page 3 of 3 )

\begin{tabular}{|c|c|c|c|c|c|c|c|c|c|c|c|c|}
\hline \multirow[b]{2}{*}{$\begin{array}{l}\text { Sample } \\
\text { Location }\end{array}$} & \multirow[b]{2}{*}{$\begin{array}{l}\text { Sample } \\
\text { Number }\end{array}$} & \multirow[b]{2}{*}{ 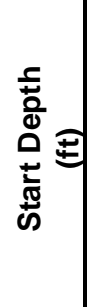 } & \multirow[b]{2}{*}{ 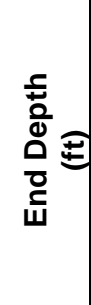 } & \multicolumn{9}{|c|}{ Contaminants of Potential Concern $(\mathrm{pCi} / \mathrm{g})$} \\
\hline & & & & 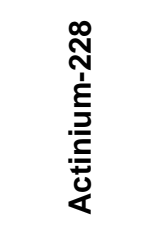 & 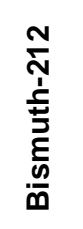 & 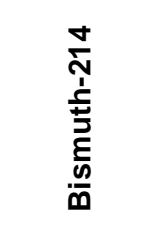 & 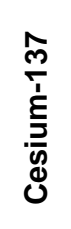 & 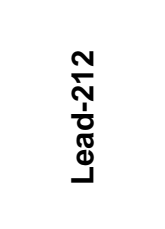 & 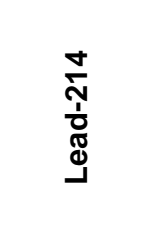 & 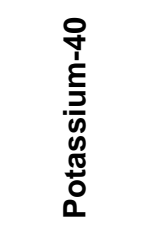 & 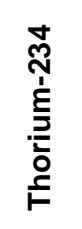 & 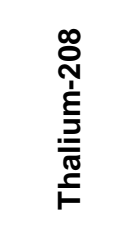 \\
\hline \multicolumn{4}{|c|}{ Preliminary Action Levels ${ }^{a, b}$} & $3.65^{\mathrm{a}}$ & $2.4^{\mathrm{b}}$ & $3.47^{b}$ & $7^{\mathrm{b}}$ & $2.9^{\mathrm{a}}$ & $2.9^{b}$ & $96^{\mathrm{a}}$ & $3.2^{b}$ & $3.4^{\mathrm{a}}$ \\
\hline E8 & FTA00113 & 0 & 1 & $2.62 \pm 0.72$ & -- & $2.08 \pm 0.54$ & -- & $2.58 \pm 0.61$ & $1.45 \pm 0.41$ & $30.2 \pm 5.5$ & -- & $0.8 \pm 0.25$ \\
\hline
\end{tabular}

aBackground concentration listed in Environmental Monitoring Report for the Proposed Ward Valley, California, Low-Level Radioactive Waste (LLRW) Facility (Atlan-Tech, 1992). ${ }^{\mathrm{b} B}$ Background concentration listed or derived in Off-Site Radiation Exposure Review Project, Phase II Soils Program (McArthur and Miller, 1989).

${ }^{\mathrm{c}}$ The normalized difference between the sample and its laboratory duplicate fell outside the established range.

$--=$ Not detected above minimum reporting limit

$\mathrm{J}=$ Estimated value

$\mathrm{pCi} / \mathrm{g}=$ Picocuries per gram

$\mathrm{ft}=$ Foot (Feet) 
Table A.3-7

\section{Soil Sample Results for Isotopic Uranium and Isotopic Plutonium, CAU 490, Station 44 Burn Area}

(Page 1 of 2)

\begin{tabular}{|c|c|c|c|c|c|c|c|}
\hline \multirow{2}{*}{$\begin{array}{l}\text { Sample } \\
\text { Location }\end{array}$} & \multirow{2}{*}{$\begin{array}{l}\text { Sample } \\
\text { Number }\end{array}$} & \multirow{2}{*}{$\begin{array}{c}\text { Start } \\
\text { Depth } \\
\text { (ft) }\end{array}$} & \multirow{2}{*}{$\begin{array}{c}\text { End } \\
\text { Depth } \\
\text { (ft) }\end{array}$} & \multicolumn{4}{|c|}{ Contaminants of Potential Concern $(\mathrm{pCi} / \mathrm{g})$} \\
\hline & & & & U-234 & U-235 & U-238 & PU-239 \\
\hline \multicolumn{4}{|c|}{ Preliminary Action Levels ${ }^{a, b}$} & $2.6^{a}$ & $0.1^{\mathrm{a}}$ & $3.2^{\mathrm{b}}$ & $0.24^{b}$ \\
\hline \multirow{2}{*}{ Trench 1-15 } & GPB00103 & 0 & 1 & $1.3 \pm 0.22$ & $0.075 \pm 0.032$ & $1.14 \pm 0.20$ & -- \\
\hline & GPB00104 & 3 & 4 & $1.83 \pm 0.30$ & $0.101 \pm 0.040$ & $1.46 \pm 0.25$ & -- \\
\hline \multirow{2}{*}{ Trench 1-30 } & GPB00105 & 0 & 1 & $2 \pm 0.32$ & $0.111 \pm 0.041$ & $1.51 \pm 0.25$ & -- \\
\hline & GPB00106 & 3 & 4 & $1.51 \pm 0.25$ & $0.117 \pm 0.042$ & $1.31 \pm 0.22$ & -- \\
\hline \multirow{2}{*}{ Trench 2-0 } & GPB00107 & 0 & 1 & $2.12 \pm 0.35$ & $0.107 \pm 0.043$ & $1.61 \pm 0.28$ & -- \\
\hline & GPB00108 & 3 & 4 & $3.59 \pm 0.57$ & $0.139 \pm 0.051$ & $2.07 \pm 0.35$ & -- \\
\hline Trench 3-0 & GPB00109 & 0 & 1 & $1.36 \pm 0.26$ & -- & $1.35 \pm 0.25$ & -- \\
\hline Trench 3-0 & GPB00110 & 3 & 4 & $2.18 \pm 0.37$ & $0.104 \pm 0.045$ & $1.75 \pm 0.31$ & -- \\
\hline Trench 3-12 & GPB00111 & 0 & 1 & $1.26 \pm 0.23$ & -- & $1.24 \pm 0.23$ & -- \\
\hline \multirow{2}{*}{ Trench 3-26 } & GPB00112 & 0 & 1 & $1.51 \pm 0.26$ & $0.117 \pm 0.043$ & $1.16 \pm 0.21$ & -- \\
\hline & GPB00113 & 3 & 4 & $2.41 \pm 0.40$ & $0.134 \pm 0.051$ & $1.81 \pm 0.31$ & -- \\
\hline \multirow{2}{*}{ Trench 3-30 } & GPB00114 & 0 & 1 & $1.34 \pm 0.24$ & -- & $1.16 \pm 0.21$ & $0.111 \pm 0.039$ \\
\hline & GPB00115 & 3 & 4 & $1.53 \pm 0.26$ & $0.076 \pm 0.036$ & $1.41 \pm 0.25$ & -- \\
\hline \multirow{2}{*}{ Trench 4-0 } & GPB00116 & 0 & 1 & $1.66 \pm 0.29$ & $0.101 \pm 0.043$ & $1.46 \pm 0.26$ & -- \\
\hline & GPB00117 & 3 & 4 & $1.35 \pm 0.24$ & -- & $1.19 \pm 0.21$ & -- \\
\hline \multirow{2}{*}{ Trench 4-2 } & GPB00118 & 20 & 22 & $1.85 \pm 0.32$ & $0.098 \pm 0.043$ & $1.52 \pm 0.27$ & -- \\
\hline & GPB00119 & 20 & 22 & $1.98 \pm 0.34$ & $0.08 \pm 0.039$ & $1.51 \pm 0.27$ & -- \\
\hline Trench 4-10 & GPB00121 & 3 & 4 & $2.22 \pm 0.36$ & $0.132 \pm 0.046$ & $1.6 \pm 0.27$ & -- \\
\hline \multirow{2}{*}{ Trench 5-6 } & GPB00122 & 0 & 1 & $1.3 \pm 0.23$ & $0.069 \pm 0.034$ & $1.04 \pm 0.19$ & -- \\
\hline & GPB00123 & 3 & 4 & $2.94 \pm 0.47$ & $0.082 \pm 0.037$ & $1.75 \pm 0.30$ & -- \\
\hline \multirow{2}{*}{ Trench 6-6 } & GPB00125 & 0 & 1 & $1.86 \pm 0.31$ & $0.139 \pm 0.050$ & $1.47 \pm 0.26$ & -- \\
\hline & GPB00126 & 3 & 4 & $3.73 \pm 0.58$ & $0.2 \pm 0.062$ & $2.11 \pm 0.35$ & -- \\
\hline \multirow{2}{*}{ Trench 7-0 } & GPB00127 & 0 & 1 & $1.68 \pm 0.28$ & $0.092 \pm 0.038$ & $1.31 \pm 0.23$ & -- \\
\hline & GPB00128 & 5 & 6 & $2.17 \pm 0.34$ & $0.182 \pm 0.053$ & $1.62 \pm 0.26$ & -- \\
\hline
\end{tabular}


Table A.3-7

\section{Soil Sample Results for Isotopic Uranium and Isotopic Plutonium, CAU 490, Station 44 Burn Area}

(Page 2 of 2)

\begin{tabular}{|c|c|c|c|c|c|c|c|}
\hline \multirow{2}{*}{$\begin{array}{l}\text { Sample } \\
\text { Location }\end{array}$} & \multirow{2}{*}{$\begin{array}{l}\text { Sample } \\
\text { Number }\end{array}$} & \multirow{2}{*}{$\begin{array}{c}\text { Start } \\
\text { Depth } \\
\text { (ft) }\end{array}$} & \multirow{2}{*}{$\begin{array}{c}\text { End } \\
\text { Depth } \\
\text { (ft) }\end{array}$} & \multicolumn{4}{|c|}{ Contaminants of Potential Concern $(\mathrm{pCi} / \mathrm{g})$} \\
\hline & & & & U-234 & U-235 & U-238 & PU-239 \\
\hline \multicolumn{4}{|c|}{ Preliminary Action Levels ${ }^{a, b}$} & $2.6^{\mathrm{a}}$ & $0.1^{\mathrm{a}}$ & $3.2^{\mathrm{b}}$ & $0.24^{b}$ \\
\hline \multirow{2}{*}{ Trench 7-4 } & GPB00129 & 0 & 1 & $1.48 \pm 0.25$ & $0.132 \pm 0.046$ & $1.3 \pm 0.22$ & -- \\
\hline & GPB00130 & 3 & 4 & $2.14 \pm 0.35$ & $0.163 \pm 0.053$ & $1.53 \pm 0.26$ & -- \\
\hline \multirow{3}{*}{ Trench 8-6 } & GPB00131 & 0 & 1 & $1.31 \pm 0.22$ & $0.133 \pm 0.046$ & $1.33 \pm 0.23$ & -- \\
\hline & GPB00132 & 3 & 4 & $2.53 \pm 0.39$ & $0.16 \pm 0.050$ & $1.7 \pm 0.27$ & -- \\
\hline & GPB00920 & 5 & 6 & $1.74 \pm 0.25$ & $0.159 \pm 0.040$ & $1.35 \pm 0.20$ & -- \\
\hline \multirow{2}{*}{ Trench 9-0 } & GPB00133 & 0 & 1 & $1.27 \pm 0.23$ & $0.114 \pm 0.044$ & $1.34 \pm 0.24(J)^{c}$ & -- \\
\hline & GPB00134 & 3 & 4 & $2.44 \pm 0.37$ & $0.129 \pm 0.042$ & $1.76 \pm 0.28(J)^{c}$ & -- \\
\hline \multirow{2}{*}{ Trench 9-12 } & GPB00135 & 0 & 1 & $1.51 \pm 0.26$ & $0.095 \pm 0.039$ & $1.24 \pm 0.22(\mathrm{~J})^{\mathrm{c}}$ & -- \\
\hline & GPB00136 & 3 & 4 & $2.09 \pm 0.36$ & $0.107 \pm 0.045$ & $1.7 \pm 0.30(\mathrm{~J})^{\mathrm{c}}$ & -- \\
\hline \multirow{2}{*}{ Trench 9-18 } & GPB00137 & 0 & 1 & $1.23 \pm 0.21$ & $0.084 \pm 0.035$ & $1.12 \pm 0.20(\mathrm{~J})^{\mathrm{c}}$ & -- \\
\hline & GPB00138 & 3 & 4 & $2.55 \pm 0.40$ & $0.122 \pm 0.044$ & $1.77 \pm 0.29(\mathrm{~J})^{\mathrm{c}}$ & -- \\
\hline \multirow{3}{*}{ Trench 10-0 } & GPB00139 & 0 & 1 & $1.32 \pm 0.23$ & $0.069 \pm 0.032$ & $1.1 \pm 0.20(\mathrm{~J})^{\mathrm{c}}$ & -- \\
\hline & GPB00140 & 0 & 1 & $1.24 \pm 0.25$ & $0.116 \pm 0.053$ & $1.21 \pm 0.24(\mathrm{~J})^{\mathrm{c}}$ & -- \\
\hline & GPB00141 & 3 & 4 & $2.48 \pm 0.34$ & $0.149 \pm 0.036$ & $1.55 \pm 0.22(J)^{c}$ & -- \\
\hline \multirow{2}{*}{ Trench $10-12$} & GPB00142 & 0 & 1 & $1.12 \pm 0.21$ & $0.148 \pm 0.052$ & $1.02 \pm 0.19(\mathrm{~J})^{\mathrm{c}}$ & $0.084 \pm 0.034$ \\
\hline & GPB00143 & 3 & 4 & $2.36 \pm 0.39$ & $0.311 \pm 0.085$ & $1.81 \pm 0.31(\mathrm{~J})^{\mathrm{c}}$ & -- \\
\hline \multirow{2}{*}{ Trench 10-16 } & GPB00144 & 0 & 1 & $1.34 \pm 0.23$ & $0.134 \pm 0.048$ & $1.14 \pm 0.20(\mathrm{~J})^{\mathrm{c}}$ & -- \\
\hline & GPB00145 & 3 & 4 & $2.15 \pm 0.33$ & $0.138 \pm 0.044$ & $1.49 \pm 0.24(\mathrm{~J})^{\mathrm{c}}$ & -- \\
\hline Trench 10-6 & GPB00146 & 3 & 4 & $2.17 \pm 0.34$ & $0.178 \pm 0.052$ & $1.43 \pm 0.24(\mathrm{~J})^{\mathrm{c}}$ & -- \\
\hline Trench 6-6 & GPB00147 & 5 & 6 & $1.85 \pm 0.31$ & -- & $1.3 \pm 0.23(\mathrm{~J})^{\mathrm{c}}$ & -- \\
\hline
\end{tabular}

aBackground concentration listed in Environmental Monitoring Report for the Proposed Ward Valley, California, Low-Level Radioactive Waste (LLRW) Facility (Atlan-Tech, 1992).

'Background concentration listed or derived in Off-Site Radiation Exposure Review Project, Phase II Soils Program (McArthur and Miller, 1989).

'Matrix spike recovery was outside the control limits.

-- = Not detected above minimum reporting limit

$\mathrm{pCi} / \mathrm{g}=$ Picocuries per gram

$\mathrm{ft}=$ Foot (Feet)

$\mathrm{U}=$ Uranium

$\mathrm{Pu}=$ Plutonium 
Table A.3-8

Soil Sample Results for Nitrocellulose, CAU 490, Station 44 Burn Area

\begin{tabular}{|c|c|c|c|c|}
\hline \multirow{2}{*}{$\begin{array}{l}\text { Sample } \\
\text { Location }\end{array}$} & \multirow{2}{*}{$\begin{array}{l}\text { Sample } \\
\text { Number }\end{array}$} & \multirow{2}{*}{$\begin{array}{l}\text { Start Depth } \\
\text { (ft) }\end{array}$} & \multirow{2}{*}{$\begin{array}{c}\text { End Depth } \\
\text { (ft) }\end{array}$} & \multirow{2}{*}{$\begin{array}{c}\text { Contaminants of Potential Concern }(\mathrm{mg} / \mathrm{kg}) \\
\text { Nitrocellulose }\end{array}$} \\
\hline & & & & \\
\hline \multicolumn{4}{|c|}{ Preliminary Action Level $^{a}$} & 10,000 \\
\hline Trench 1-0 & GPB00102 & 3 & 4 & $17(\mathrm{~J})^{\mathrm{b}, \mathrm{c}}$ \\
\hline Trench 1-15 & GPB00104 & 3 & 4 & $10(\mathrm{~J})^{\mathrm{C}}$ \\
\hline \multirow{2}{*}{ Trench 1-30 } & GPB00105 & 0 & 1 & $110(\mathrm{~J})^{\mathrm{c}}$ \\
\hline & GPB00106 & 3 & 4 & $140(J)^{\mathrm{C}}$ \\
\hline \multirow{2}{*}{ Trench 2-0 } & GPB00107 & 0 & 1 & $130(\mathrm{~J})^{\mathrm{C}}$ \\
\hline & GPB00108 & 3 & 4 & $890(J)^{c}$ \\
\hline Trench 3-26 & GPB00113 & 3 & 4 & 67 \\
\hline Trench 3-30 & GPB00115 & 3 & 4 & 12 \\
\hline Trench 4-0 & GPB00117 & 3 & 4 & 92 \\
\hline \multirow{2}{*}{ Trench 4-2 } & GPB00118 & 20 & 22 & $90(\mathrm{~J})^{\mathrm{b}}$ \\
\hline & GPB00119 & 20 & 22 & $100(J)^{b}$ \\
\hline Trench 4-10 & GPB00121 & 3 & 4 & $34(J)^{b}$ \\
\hline Trench 5-6 & GPB00123 & 3 & 4 & $7.6(\mathrm{~J})^{\mathrm{b}}$ \\
\hline Trench 7-0 & GPB00128 & 5 & 6 & $53(\mathrm{~J})^{\mathrm{b}}$ \\
\hline \multirow{2}{*}{ Trench 7-4 } & GPB00129 & 0 & 1 & $10(\mathrm{~J})^{\mathrm{b}}$ \\
\hline & GPB00130 & 3 & 4 & $84(J)^{b}$ \\
\hline \multirow{2}{*}{ Trench 8-6 } & GPB00132 & 3 & 4 & $82(J)^{b}$ \\
\hline & GPB00920 & & & $34(J)^{b}$ \\
\hline Trench 9-12 & GPB00136 & 3 & 4 & $51(\mathrm{~J})^{\mathrm{b}}$ \\
\hline Trench 9-18 & GPB00138 & 3 & 4 & $73(\mathrm{~J})^{\mathrm{b}}$ \\
\hline Trench 10-12 & GPB00143 & 3 & 4 & $8.4(J)^{b}$ \\
\hline Trench 10-16 & GPB00145 & 3 & 4 & $8(J)^{b}$ \\
\hline Trench 10-6 & GPB00146 & 3 & 4 & $6.6(\mathrm{~J})^{\mathrm{b}}$ \\
\hline
\end{tabular}

${ }^{\mathrm{a} D O E} / \mathrm{NV}, 2000$

${ }^{\mathrm{b}}$ Exceeded holding time

${ }^{\mathrm{c}}$ Sample temperature not documented during storage

$\mathrm{J}=$ Estimated value

$\mathrm{mg} / \mathrm{km}$ = Milligrams per kilogram 


\section{A.3.10 Rocket Resin Results from GPBA}

A resin sample (GPB00124) collected for waste management purposes from the rocket that was found in Pit Two had the following COPCs detected (Table A.3-9): calcium; aluminum; antimony; magnesium; iron; lead; uranium-235; uranium-238; di-n-butylphthalate; 1, 4-dichlorobenzene; 1,2, 4-trichlorobenzene; 1,2-dichlorobenzene; 3-nitrotoluene; 2,4-dinitrotoluene; 2-amino-4,6-dnt; nitrobenzene, nitroglycerin, trichlorofluoromethane, acetone, diesel-range organics, selenium, zinc, chromium, copper, and manganese.

The analytical results of the JATO rocket resin were inconclusive based on SVOCs analysis and were resampled (GPB00700) for TCLP SVOC analysis to determine if it was a nonhazardous material. The results were nondetect. The JATO rocket was removed from this CAS for proper disposal. 
Table A.3-9

\section{Summary of Rocket Resin Analytical Results From GPBA Detected Above Minimum Detectable Concentrations, CAU 490, Station 44 Burn Area}

\begin{tabular}{|c|c|c|c|}
\hline Sample Number & Parameter & Result & Units \\
\hline GPB00124 & Calcium & 260 & $\mathrm{mg} / \mathrm{kg}$ \\
\hline GPB00124 & Aluminum & 170 & $\mathrm{mg} / \mathrm{kg}$ \\
\hline GPB00124 & Antimony & $34(J)^{a}$ & $\mathrm{mg} / \mathrm{kg}$ \\
\hline GPB00124 & Magnesium & 180 & $\mathrm{mg} / \mathrm{kg}$ \\
\hline GPB00124 & Iron & 7,100 & $\mathrm{mg} / \mathrm{kg}$ \\
\hline GPB00124 & Lead & 6 & $\mathrm{mg} / \mathrm{kg}$ \\
\hline GPB00124 & Uranium-234 & $0.248 \pm 0.056$ & $\mathrm{pCi} / \mathrm{g}$ \\
\hline GPB00124 & Uranium-238 & $0.158 \pm 0.042$ & $\mathrm{pCi} / \mathrm{g}$ \\
\hline GPB00124 & Di-N-Butylphthalate & $500,000(\mathrm{~J})^{\mathrm{b}, \mathrm{c}}$ & $\mu \mathrm{g} / \mathrm{kg}$ \\
\hline GPB00124 & 1,4-Dichlorobenzene & $2,500(\mathrm{~J})$ & $\mu \mathrm{g} / \mathrm{kg}$ \\
\hline GPB00124 & 1,2,4-Trichlorobenzene & 6,600 & $\mu \mathrm{g} / \mathrm{kg}$ \\
\hline GPB00124 & 1,2-Dichlorobenzene & 62,000 & $\mu \mathrm{g} / \mathrm{kg}$ \\
\hline GPB00124 & 3-Nitrotoluene & $20(J)^{b, d, e}$ & $\mathrm{mg} / \mathrm{kg}$ \\
\hline GPB00124 & 2,4-Dinitrotoluene & $0.63(J)^{b, d, e}$ & $\mathrm{mg} / \mathrm{kg}$ \\
\hline GPB00124 & 2-Amino-4,6-DNT & $1.3(\mathrm{~J})^{\mathrm{b}, \mathrm{d}, \mathrm{e}}$ & $\mathrm{mg} / \mathrm{kg}$ \\
\hline GPB00124 & Nitrobenzene & $60(J)^{f, b, d, g}$ & $\mathrm{mg} / \mathrm{kg}$ \\
\hline GPB00124 & Nitroglycerin & $2.5(\mathrm{~J})^{\mathrm{h}}$ & $\mathrm{mg} / \mathrm{kg}$ \\
\hline GPB00124 & Trichlorofluoromethane & $2,700(J)^{i, j}$ & $\mu \mathrm{g} / \mathrm{kg}$ \\
\hline GPB00124 & Acetone & 16,000 & $\mu \mathrm{g} / \mathrm{kg}$ \\
\hline GPB00124 & Diesel Range Organics & 110 & $\mathrm{mg} / \mathrm{kg}$ \\
\hline GPB00124 & Selenium & 1.2 & $\mathrm{mg} / \mathrm{kg}$ \\
\hline GPB00124 & Zinc & 2 & $\mathrm{mg} / \mathrm{kg}$ \\
\hline GPB00124 & Chromium & 29 & $\mathrm{mg} / \mathrm{kg}$ \\
\hline GPB00124 & Copper & 2.9 & $\mathrm{mg} / \mathrm{kg}$ \\
\hline GPB00124 & Manganese & 33 & $\mathrm{mg} / \mathrm{kg}$ \\
\hline
\end{tabular}

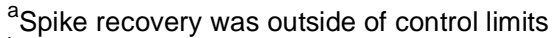

${ }^{b}$ Matrix affects may exist

${ }^{\mathrm{c}}$ Surrogates diluted out

${ }^{\mathrm{d}}$ Compounds/components coelute

${ }^{\mathrm{e}}$ Surrogate recovery $<10 \%$

${ }^{f}$ Value was above the calibration range

${ }^{g}$ Peak pattern mismatch

${ }^{\mathrm{h}}$ Surrogate recovery exceeded the upper limits

${ }^{i}$ CCV percent $>25 \%$

${ }^{\mathrm{j}}$ Percent RSD exceeded $30 \%$
$\mathrm{J}=$ Estimated value

$\mathrm{mg} / \mathrm{L}=$ Milligrams per liter $\mu \mathrm{g} / \mathrm{L}=$ Micrograms per liter $\mathrm{pCi} / \mathrm{g}=$ Picocuries per gram 


\section{A.4.0 Quality Assurance}

The results of QA/QC activities for CAU 490 corrective action investigation sampling events are summarized in the following text. Detailed information regarding the QA program is contained in the Industrial Sites QAPP (DOE/NV, 1996b).

Quality control results are typically discussed in terms of precision, accuracy, representativeness, completeness, and comparability. These terms are described in the following sections.

\section{A.4.1 Precision}

Precision is a quantitative measure of the variability of a group of measurements from their average value. Precision is assessed for inorganic analysis by collecting and analyzing duplicate field samples and comparing the results with the original sample. Precision is also assessed by creating, preparing, analyzing, and comparing laboratory duplicates from one or more field samples in inorganic analyses and matrix spike/matrix spike duplicate (MS/MSD) samples for organic analyses. Precision is reported as relative percent difference (RPD), which is calculated as the difference between the measured concentrations of duplicate samples, divided by the average of the two concentrations, and multiplied by 100. Any deviation from these requirements has been documented and explained and the related data qualified accordingly. The qualification process is described in Section A.4.7.1.

\section{A.4.2 Accuracy}

Analytical accuracy is defined as the nearness of a measurement to the true or accepted reference value. It is the composite of the random and systematic components of the measurement system and measures bias in a measurement system. The random component of accuracy is measured and documented through the analyses of spiked samples. Sampling accuracy is assessed by evaluating the results of spiked samples and laboratory control samples. Accuracy measurements are calculated as percent recovery $(\% \mathrm{R})$ by dividing the measured sample concentration by the true concentration and multiplying the quotient by 100 . 
Field accuracy is assessed by confirming that the documents of record track the sample from origin, through transfer of custody, to disposal. The goal of field accuracy is for all samples to be collected from the correct locations at the correct time, placed in a correctly labeled container with the correct preservative, and sealed with custody tape to prevent tampering. There were refrigerator excursions that occurred during CAU 490 sampling. These temperature excursions were accounted for during data validation. Affected samples were qualified as estimated (J or UJ) for SVOC, pesticide, PCBs, TPH diesel-range organics, and RCRA Metals. Detected VOCs and TPH gasoline-range organics were qualified estimated $(\mathrm{J})$ and nondetect sample results for VOC and TPH gasoline-range organics were rejected during data validation.

\section{A.4.3 Representativeness}

Representativeness expresses the degree to which sample data accurately and precisely represent a characteristic of a population, parameter variations at a sampling point, or an environmental condition (EPA, 1987). Sample representativeness was achieved through the implementation of a sampling program designed to ensure proper sampling locations, number of samples, and the use of validated analytical methods. Representativeness was assessed through analysis of duplicate samples. Representativeness of the samples taken in this sampling event was assured by collecting the specified number of samples (DOE/NV, 2000) and by analyzing them using the approved analytical methods shown in Table A.3-2.

\section{A.4.4 Completeness}

Completeness is defined as the percentage of measurements made that are judged to be valid. A sampling and analytical requirement of 80 percent completeness was established and achieved for this project (DOE/NV, 1996b).

The specified sampling locations were utilized as planned. All samples were collected as specified in the CAIP (DOE/NV, 2000). All sample containers reached the laboratory intact and properly preserved (when applicable). Sample temperature was maintained during shipment to the laboratory, and sample chain of custody was maintained during sample storage and/or shipment (DOE/NV, 1996b). 


\section{A.4.5 Comparability}

Comparability is a qualitative parameter expressing the confidence with which one data set can be compared to another (EPA, 1987). To ensure comparability, the field and sampling activities were performed and documented in accordance with approved procedures, and all samples were collected in accordance with the CAIP, with the exception of samples affected by the refrigerator excursions (DOE/NV, 2000). Approved standardized methods and procedures were also used to analyze and report the data (e.g., Contract Laboratory Program [CLP] and/or CLP-like data packages). This approach ensures that the data from this project can be compared to other data sets. Based on the minimum comparability requirements specified in the Industrial Sites QAPP (DOE/NV, 1996b), all requirements were met.

Field (i.e., sample-handling) documentation, laboratory nonconformance reports, and the precision and accuracy of quality-control sample results were evaluated for their effect on the results of the associated environmental soil samples. The environmental sample results were then qualified according to processes outlined in the following sections. Documentation of the data qualifications resulting from these reviews is retained in project files as both hard copy and electronic media.

\section{A.4.6 Tier I and Tier II Data Evaluations}

All laboratory data from samples collected at CAU 490 have been evaluated for data quality according to EPA Functional Guidelines (EPA, 1994 and 1999). These guidelines were implemented in a tiered process and are presented in the following text. There was one sample that was initially rejected; however, the sample was reextracted and reanalyzed and the subsequent result was usable. Only valid data, whether estimated (i.e., J-qualified) or not, were used.

Changes resulting from the data evaluation process are documented in project files and summarized in memoranda for each sample delivery group (SDG). These memoranda are maintained with the SDGs in the project files. 


\section{A.4.6.1 Tier I Evaluation}

Tier I evaluation for both chemical and radiological analysis examines (but is not limited to):

- Sample count/type consistent with chain of custody

- Analysis count/type consistent with chain of custody

- Correct sample matrix

- Significant problems stated in cover letter or case narrative

- Completeness of certificates of analysis

- Completeness of CLP or CLP-like packages

- Completeness of signatures, dates, and times on chain of custody

- Condition-upon-receipt variance form included

- Requested analyses performed on all samples

- Date received/analyzed given for each sample

- Correct concentration units indicated

- Electronic data transfer supplied

- Results reported for field and laboratory QC samples

- Whether or not the deliverable met the overall objectives of the project

\section{A.4.6.2 Tier II Evaluation}

Tier II evaluation for both chemical and radiological analysis examines (but is not limited to):

\section{Chemical:}

- Correct detection limits achieved

- Sample date, preparation date, and analysis date for each sample

- Holding time criteria met

- QC batch association for each sample

- Cooler temperature upon receipt

- Sample $\mathrm{pH}$ for aqueous samples, as required

- Detection limits properly adjusted for dilution, as required

- Blank contamination evaluated and applied to sample results/qualifiers

- Matrix spike/matrix spike duplicate percent recoveries (\%R) and RPDs evaluated and applied to laboratory results/qualifiers

- Field duplicate RPDs evaluated using professional judgment and applied to laboratory results/qualifiers

- Laboratory duplicate RPDs evaluated and applied to laboratory results/qualifiers

- Surrogate \%Rs evaluated and applied to laboratory results/qualifiers

- Laboratory control sample \%R evaluated and applied to laboratory results/qualifiers

- Initial and continuing calibration evaluated and applied to laboratory results/qualifiers

- Internal standard evaluated and applied to laboratory results/qualifiers 
- Mass spectrometer tuning criteria

- Organic compound quantitation

- ICP interference check sample evaluation

- Graphite furnace atomic absorption quality control

- ICP serial dilution effects

- Recalculation of 10 percent of laboratory results from raw data

\section{Radioanalytical:}

- Correct detection limits achieved

- Blank contamination evaluated and applied to sample results/qualifiers

- Certificate of Analysis consistent with data package documentation

- Quality control sample results (duplicates, laboratory control samples, laboratory blanks) evaluated and applied to laboratory result qualifiers

- Sample results, error, and minimum detectable activity evaluated and applied to laboratory result qualifiers

- Detector system calibrated to National Institute for Standards and Technology (NIST)-traceable sources

- Calibration sources preparation was documented, demonstrating proper preparation and appropriateness for sample matrix, emission energies, and concentrations

- Detector system response to daily, weekly, and monthly background and calibration checks, which may include peak energy, peak centroid, peak full-width half-maximum, and peak efficiency, depending on the detection system

- Tracers NIST-traceable, appropriate for the analysis performed, and recoveries that met QC requirements

- Documentation of all QC sample preparation complete and properly performed

- QC sample results (e.g., calibration source concentration, percent recovery, and RPD) verified

- Spectra lines, emissions, particle energies, peak areas, and background peak areas support the identified radionuclide and its concentration

- Recalculation of 10 percent of laboratory results from raw data 


\section{A.4.6.3 Tier III Evaluation}

The Tier III review looks at all the items evaluated in the Tier II evaluation, but for only a limited number of samples (typically 5 percent). It serves as a check on the Tier II process. The Tier III review includes the additional evaluations:

\section{Chemical:}

- Recalculation of laboratory results from raw data for all samples submitted for Tier III

\section{Radioanalytical:}

- Radionuclides and their concentration appropriate considering their decay schemes, half-lives, and process knowledge and history of the facility and CAU

- Each identified line in spectra verified against emission libraries and calibration results

- Independent identification of spectra lines, area under the peaks, and quantification of radionuclide concentration in a random number of sample results

- Recalculation of laboratory results from raw data for all samples submitted for Tier III

A Tier III review of at least five percent of the sample analytical data was performed by Techlaw, in Lakewood, Colorado. As a result of the Tier III review, all of the criteria were met by Paragon Analytics, Inc.

\section{A.4.7 Quality Control Samples}

Sixty-six quality control samples (i.e., 37 trip blanks, 4 equipment rinsate blanks, 7 field blanks, 4 source blanks, 8 field duplicates, and 6 MS/MSD) were collected and submitted for laboratory analyses, as shown in Table A.3-1. The blanks and duplicates were assigned individual sample numbers and sent to the laboratory "blind." Additional samples were selected by the laboratory to be analyzed as laboratory duplicates. Documentation related to the collection and analysis of these samples is retained in project files. 


\section{A.4.7.1 Field Quality Control Samples}

Review of the field-collected blank analytical data for CAU 490 investigation indicates that cross-contamination from field methods may have occurred during sample collection and/or during sample shipment. Although the detected concentrations were above the contract-required detection limit, the PALs were not exceeded and the results did not have an impact on the investigation. Field blanks, source blanks, and equipment rinsate blanks were analyzed for the parameters listed in Table A.3-1 and trip blanks were analyzed for total VOCs only.

Eight field duplicate soil samples were sent as blind samples to the laboratory to be analyzed for the analytical parameters listed in Table A.3-1. For these samples, the duplicate results precision (i.e., RPD between the environmental sample results and their corresponding field duplicate sample results) were evaluated to the guidelines set forth in EPA Functional Guidelines (EPA, 1994 and 1999). The EPA Functional Guidelines state that there are no required review criteria for field duplicate analyses comparability, but allow the data reviewer to exercise professional judgment. The RPD between some environmental sample results and their corresponding field duplicate sample results exceeded the 20 percent criteria stated in the Industrial Sites QAPP (DOE/NV, 1996b) for some target analytes. The variability in the results between the environmental samples and their corresponding field duplicate samples could be attributed to nonhomogeneous samples and the difficulties associated with collecting identical soil field samples. It is expected that soil field duplicate results will have a greater variance than water matrices.

The laboratory duplicate samples were compared to the criteria set forth in the EPA Functional Guidelines (EPA, 1994) and the associated sample results were qualified accordingly. Both detections and nondetections have been qualified as estimated ( $\mathrm{J}$ and $\mathrm{UJ}$, respectively) if the relative percent difference between an environmental sample and its laboratory duplicate fell outside established criteria.

Six field samples were selected for use as MS/MSD samples. The $\% \mathrm{R}$ of these samples (a measure of accuracy) and the RPDs in these sample results (a measure of precision) were compared to EPA Functional Guidelines criteria (EPA, 1994 and 1999). The results were used to qualify associated environmental sample results accordingly. 
The EPA Functional Guidelines for review of organic data state that no data qualification action is taken on the basis of MS/MSD results alone (EPA, 1999). The data reviewer exercises professional judgment in considering these results in conjunction with the results of laboratory control samples (LCSs) and other QC criteria in applying qualifications to the data.

The EPA Functional Guidelines for inorganic data review allows professional judgment to be applied in evaluating the results of matrix spikes (EPA, 1994). Generally, if spike recovery is greater than the upper acceptance limits (>125\%), nondetections are acceptable for use. If spike recovery is greater than the upper acceptance limit (>125\%) or less than the lower acceptance limit $(<75 \%)$, positive results are qualified as estimated $(\mathrm{J})$. If spike recovery falls within the range of $30-74 \%$, nondetections are qualified as estimated (UJ). If spike recovery is less than 30 percent (grossly low), positive results are not qualified, and nondetections are qualified as unusable (R).

\section{A.4.7.2 Laboratory Quality Control Samples}

Analysis of method QC blanks and surrogate spikes for organic analyses, method blanks, preparation blanks, initial and continuing calibration blanks for total metals, and LCS were performed for each SDG by Paragon Analytical Services, Fort Collins, Colorado. The results of these analyses were used to qualify associated environmental sample results according to EPA Functional Guidelines (EPA, 1994 and 1999).

The EPA Functional Guidelines (EPA, 1994 and 1999) state that no qualification action is taken if a compound is found in an associated blank, but not in the sample, or if a compound is found in the sample, but not in an associated blank. The action taken when a compound is detected in both the sample and the associated blank varies depending upon the analyte involved and is described as "The 5X/10X Rule."

For most VOCs, SVOCs, herbicides, PCBs, TPH (diesel-range and gasoline-range organics), explosives, nitroglycerine, nitroguanidine, nitrocellulose, and pesticides, if an analyte is detected in 
the sample and was also detected in an associated blank, the result is qualified as undetected (U) if the sample concentration is less than five times $(5 \mathrm{X})$ the blank concentration.

For the common laboratory contaminants (e.g., methylene chloride, acetone, 2-butanone [methyl ethyl ketone or MEK], and phthalate esters [especially bis (2-ethylhexyl) phthalate]), the factor is raised to ten times $(10 \mathrm{X})$ the blank concentration. The sample result is elevated to the quantitation limit if it is less than the quantitation limit or remains unaltered if the sample result is greater than or equal to the quantitation limit, and qualified as undetected (U).

For inorganics (i.e., metals), sample results greater than the instrument detection limit but less than five times $(5 \mathrm{X})$ the amount found in an associated blank, are qualified as undetected (U). There are no common metallic laboratory contaminants, so there is no "10X rule" for metals, and the sample result is never altered. When applying the $5 \mathrm{X}$ criteria to soil sample data or calibration blank data, the raw data results are used to evaluate and qualify the reported results on the Certificate of Analysis.

Surrogate spikes, or system monitoring compounds, are added to the environmental samples analyzed by chromatographic techniques for VOCs, SVOCs, pesticides, PCBs, nitroglycerine, herbicides, gasoline, and diesel. Surrogate compounds are analytes that are not expected to be present in associated environmental samples, but behave similar to target compounds chromatographically. Known amounts of each surrogate are added prior to sample preparation and are carried throughout the preparation/analysis procedure. The percent recoveries of these surrogate compounds give some measure of the anticipated recoveries of the target compounds whose chromatographic behavior they mimic.

If any surrogate percent recoveries are out of the acceptable range (which differs for each surrogate in each method), laboratory protocol requires the sample be reprepared and/or reanalyzed. When the surrogate recoveries are acceptable on the second run, only the second analysis results are reported. When both analyses yield the same unacceptable range, the results of both analyses are reported. 
The evaluation of surrogate spike recovery results is not straightforward. The functional guidelines suggest several optional approaches, but require the data reviewer to exercise professional judgment in reviewing surrogate data and qualifying associated data as estimated ( $\mathrm{J}$ or $\mathrm{UJ}$, for detections or nondetections, respectively) or unusable (R).

One laboratory duplicate analysis for metals was performed for each SDG that reported total metals. The duplicate results are compared to the results of the original sample to give a measure of analytical laboratory precision. If the results from a duplicate analysis for a particular analyte fall outside the control limits, the EPA Functional Guidelines for Inorganic Data Review (EPA, 1994) call for all results for that analyte in all associated samples of the same matrix to be qualified as estimated (J).

Laboratory control samples, also known as blank spikes, consist of known quantities of target compounds added to purified sand or deionized, distilled water, prepared and analyzed along with the environmental samples in the sample delivery group. The percent recoveries of the compounds in the LCS give a measure of laboratory accuracy. The functional guidelines call for the data reviewer to use professional judgment to qualify associated data according to established criteria. Documentation of data qualification resulting from the application of these guidelines is retained in project files as both hard copy and electronic media.

\section{A.4.8 Field Nonconformances}

During the corrective action investigation, the DOE/NV Environmental Management Office conducted a surveillance of the field sampling procedures to verify that sampling activities were performed in accordance with applicable requirements. The results of the surveillance indicated no findings, deficiencies, or nonconformances with sampling activities as they met the requirements of the plans and procedures governing the activities at the CAU.

An independent internal audit was conducted and two nonconformances were issued because applicable approved contractor procedures were not followed. One nonconformance was that the sample temperatures were not properly documented during storage in the field. Another nonconformance involved a lapse in chain-of-custody during sample transport in the field area. Both nonconformances have had corrective actions to prevent reoccurrence. Sample quality was 
affected and, as a result, some data were qualified. Documentation of these results is retained in project files.

\section{A.4.9 Laboratory Nonconformances}

Laboratory nonconformances are generally due to inconsistencies in analytical instrumentation operation, sample preparation, extractions, and fluctuations in internal standard and calibration results. A laboratory nonconformance resulted from failure to report the required initial calibration blank (ICB) data. The laboratory analyzed the ICB sample but the data was inadvertently not saved or printed. Another laboratory nonconformance resulted from high concentrations of methylene chloride, which is a common laboratory contaminant. The method blank concentration was greater than five-times the reporting limit. These nonconformances have been accounted for in the data qualification process. Documentation of these results is retained in project files. 


\section{A.5.0 Summary}

Analysis of the data generated from corrective action investigation activities at CAU 490 indicates the following at the four CASs:

\section{Fire Training Area (CAS 03-56-001-03BA)}

- At FTA all concentrations of total VOCs and total SVOCs in soil samples were below the PALs outlined in the CAIP (DOE/NV, 2000). Additionally, gamma spectrometry analysis results for soil samples are not considered to be statistically different from their respective established background levels and, therefore, are below PALs.

- All concentrations of total RCRA metals in soil samples were below PALs established in the CAIP (DOE/NV, 2000), except for arsenic. Although the concentrations of arsenic exceeded the PAL, the concentrations are considered representative of ambient conditions for the TTR.

- Total petroleum hydrocarbons exceeded the NDEP action level of $100 \mathrm{mg} / \mathrm{kg}$ for TPH-diesel in 5 of the 18 soil samples collected. The 5 samples that exceeded the NDEP action level were collected from two of the five locations within the excavations.

\section{Station 44 Burn Area (CAS RG-56-001-RGBA)}

- At STA44 all concentrations of total VOCs, total SVOCs, and TPH (diesel-range organics) in soil samples were below the PALs outlined in the CAIP (DOE/NV, 2000). Additionally, gamma spectrometry analysis results for soil samples are not considered to be statistically different from their respective established background levels and, therefore, are below PALs.

- All concentrations of total RCRA metals in soil samples were below PALs established in the CAIP (DOE/NV, 2000), except for arsenic. Although the concentrations of arsenic exceeded the PAL, the concentrations are considered representative of ambient conditions for the TTR.

\section{Sandia Service Yard (CAS 03-58-001-03FN)}

- At SSY all concentrations of total VOCs, total SVOCs, total pesticides, and total PCBs in soil samples were below the PALs outlined in the CAIP (DOE/NV, 2000). Additionally, gamma spectrometry analysis results for soil samples are not considered to be statistically different from their respective established background levels; therefore, are below PALs. 
- All concentrations of total RCRA metals in soil samples were below PALs established in the CAIP (DOE/NV, 2000), except for arsenic. Although the concentrations of arsenic exceeded the PAL, the concentrations are considered representative of ambient conditions for the TTR.

- Total petroleum hydrocarbons exceeded the NDEP action level of $100 \mathrm{mg} / \mathrm{kg}$ for TPH-diesel in 7 of the 55 near-surface soil samples collected. The 7 samples that exceeded the action level were collected from 5 of the 26 locations. The NDEP action level for TPH-gasoline was not exceeded at any of the SSY locations.

\section{Gun Propellant Burn Area (CAS 09-54-001-09L2)}

- At GPBA all concentrations of total VOCs, total SVOCs, TPH (diesel-range organics), nitoglycerine, nitroguanidine, nitroaromatics and nitroamines, and nitrocellulose in soil samples were below the PALs outlined in the CAIP. Additionally, the radionuclides isotopic plutonium and isotopic uranium analysis results for soil samples are not considered to be statistically different from their respective established background levels; therefore, they are below PALs.

- All concentrations of total RCRA metals in soil samples were below PALs established in the CAIP, except for arsenic. Although the concentrations of arsenic exceeded the PAL, the concentrations are considered representative of ambient conditions for the TTR. Because of an elevated level of total chromium (140 mg/kg for sample GPB00111), the TCLP for this sample was run. The TCLP result is nondetect.

- Analytical results from the JATO rocket resin sample (GPB00124) collected from the exterior surface at GPBA indicated detection of COPCs to include: calcium; aluminum; antimony; magnesium; iron; lead; uranium-235; uranium-238; di-n-butylphthalate; 1, 4-dichlorobenzene; 1,2, 4-trichlorobenzene; 1,2-dichlorobenzene; 3-nitrotoluene; 2,4-dinitrotoluene; 2-amino-4,6-dnt; nitrobenzene, nitroglycerin, trichlorofluoromethane, acetone, diesel-range organics, selenium, zinc, chromium, copper, and manganese. The analytical results of the JATO rocket resin were inconclusive based on SVOCs analysis and were resampled (GPB00700) for TCLP SVOC analysis to determined if it was a nonhazardous material. The results were nondetect. The JATO rocket was removed from this CAS for proper disposal. 


\section{A.6.0 References}

American Society for Testing and Materials. 1997a. Standard Test Method for Isotopic Uranium in Water by Radiochemistry, D-3973-97. Philadelphia, PA.

American Society for Testing and Materials. 1997b. Standard Test Methodfor Plutonium in Water by Radiochemistry, D-3865. Philadelphia, PA.

American Society for Testing and Materials. 1997c. Standard Test Method for Strontium-90 in Water by Radiochemistry, D5811-95. Philadelphia, PA.

ASTM, see American Society for Testing and Materials.

Atlan-Tech. 1992. Environmental Monitoring Report for the Proposed Ward Valley, California, Low-Level Radioactive Waste (LLRW) Facility. Rosewall, GA.

CFR, see Code of Federal Regulations.

Code of Federal Regulations. 1999. Title 40 CFR Parts 260-282, "RCRA Regulations."

Washington, DC: U.S. Government Printing Office.

DOE, see U.S. Department of Energy.

DOE/NV, see U.S. Department of Energy, Nevada Operations Office.

EG\&G/EM, see EG\&G Energy Measurements.

EG\&G Energy Measurements. 1980. Aerial Photo numbers 3310-012, 3310-021, and 3310-025, August. Nellis Air Force Base, NV: Remote Sensing Laboratory Photo Library.

EG\&G Energy Measurements. 1988. Aerial Photo numbers 5956--023, 5956-026, and 5956-027, 10 April. Nellis Air Force Base, NV: Remote Sensing Laboratory Photo Library.

EPA, see U.S. Environmental Protection Agency.

FFACO, see Federal Facility Agreement and Consent Order.

Federal Facility Agreement and Consent Order. 1996 (as amended). Agreed to by the State of Nevada, the U.S. Department of Energy, and the U.S. Department of Defense.

IT, see IT Corporation. 
IT Corporation. 1997. Initial Surface Geophysical Survey Report for the Tonopah Test Range Environmental Restoration Sites, Volume 1 of 2, ITLV10972--93. Las Vegas, NV.

IT Corporation. 2000. Site-Specific Health and Safety Plan (SSHASP), Station 44 Burn Area, Tonopah Test Range. Las Vegas, NV.

McArthur, R.D., and F.L. Miller. 1989. Off-Site Radiation Exposure Review Project, Phase II Soil Program, DOE/NV/10384--23. Las Vegas, NV: Desert Research Institute.

Moore, J., Science Applications International Corporation. 1999. Memorandum to M. Todd (SAIC), entitled: "Background Concentrations for NTS and TTR Soil Samples," 3 February. Las Vegas, NV: ITLV

NAC, see Nevada Administrative Code.

NBMG, see Nevada Bureau of Mines and Geology.

Nevada Administrative Code. 1999. NAC 445A.2272, "Contamination of Soil: Order by Director of Corrective Action; Factors to be Considered in Determining Whether Corrective Action is Required." Carson City, NV.

Nevada Bureau of Mines and Geology. 1998. Mineral and Energy Resource Assessment of the Nellis Air Force Range, Open-File Report 98-1. Reno, NV.

Paragon Analytical Laboratory. 1983. Indiana Army Ammunition Plant Contamination Survey: Analytical Procedure for Nitrocellulose. Fort Collins, CO.

Paragon Analytical Laboratory. 2000. Nitrocellulose in Water Procedure provided by ERDC, Cold Regions Research and Engineering Laboratory, Hanover, New Hampshire. Fort Collins, CO.

SNL, see Sandia National Laboratories.

Sandia National Laboratories. 1999. 1998 Annual Site Environmental Report, Tonopah Test Range, Nevada, SAND99-2279. Albuquerque, NM.

U.S. Army Corps of Engineers. 2000. Cold Region Research and Engineering Laboratory Special Report: Analytical Methods for Determining Nitroguanidine in Soil and Water. Hanover, New Hampshire.

U.S. Department of Energy. 1992. Environmental Measurements Laboratory Procedures Manual, HASL-300, 28th Edition, Vol. 1. New York, NY.

U.S. Department of Energy. 1997. The Procedures Manual of the Environmental Measurements Laboratory, Vol. 1, 28th Edition, HASL-300. Washington, DC. 
U.S. Department of Energy, Nevada Operations Office. 1996a. Corrective Action Unit Work Plan, Tonopah Test Range, Nevada, Rev. 0, DOE/NV--443. Las Vegas, NV.

U.S. Department of Energy, Nevada Operations Office. 1996b. Industrial Sites Quality Assurance Project Plan, Nevada Test Site, Nevada, Rev. 1, DOE/NV--372. Las Vegas, NV.

U.S. Department of Energy, Nevada Operations Office. 1998. Corrective Action Decision Document for the Area 3 Landfill Complex, Tonopah Test Range, Nevada, Corrective Action Unit 424, Rev. 0, DOE/NV--496. Las Vegas, NV.

U.S. Department of Energy, Nevada Operations Office. 2000. Corrective Action Investigation Plan (CAIP) for Corrective Action Unit 490: Station 44 Burn Area, Tonopah Test Range, Nevada, DOE/NV--613, Rev. 0. Las Vegas, NV.

U.S. Environmental Protection Agency. 1980. Prescribed Procedures for Measurement of Radioactivity in Drinking Water, EPA-600/4-80-032. Washington, DC.

U.S. Environmental Protection Agency. 1987. Data Quality Objectives for Remedial Response Activities, EPA/540/G-87-003. Washington, DC.

U.S. Environmental Protection Agency. 1994. Contract Laboratory Program National Functional Guidelines for Inorganic Data Review, EPA 540/R-94/013. Washington, DC.

U.S. Environmental Protection Agency. 1996. Test Methods for Evaluating Solid Waste, Physical/Chemical Methods, SW-846, CDROM, CDROM PB97-5019286GEI (CDROM contains updates 1986, 1992, 1994, and 1996). Washington, DC.

U.S. Environmental Protection Agency. 1998. Memo from S.J. Smucker to PRG Table Mailing List regarding Region 9 Preliminary Remediation Goals (PRGs), 1 August.

San Francisco, CA.

U.S. Environmental Protection Agency. 1999. Contract Laboratory Program National Functional Guidelines for Organic Data Review, EPA 540/R-99/008. Washington, DC.

U.S. Environmental Protection Agency. 2000. Guidance for the Data Quality Objectives Process, EPA QA/G-4, EPA/600/R-96/005. Washington, DC. 


\section{Appendix B}

\section{Cost Estimates for CAU 490}

(As received from Bechtel Nevada $[\mathrm{BN}]$ ) 
ASSUMPTIONS:

* Work to be preformed by BN during normal work day (No provisions for overtime provided). Shifts are based on 10 hours per day / 4-days per week.

- Efficiencies will be realized as work will be performed on similar activities completed in parallel or concurrently

* This estimate does not include costs for preparation of Corrective Action Plan (CAP) or a Closure Report

* Soil borrow area is within one ( 1 ) mile of site.

\section{ESCALATION:}

No escalation factors have been applied. All costs are in FY01 dollars.

\section{CONTINGENCY:}

Contingency costs are not included in this estimate.

\section{RATES:}

FY01rates (Rev 0) effective 10/1/00 were applied using the BN FY00 cost model.

\section{COST ALTERNATIVES SUMMARY:}

Alternative I: No Action To Be Taken

Alternative II: Closure In Place-No Further Action with Administrative Controls.

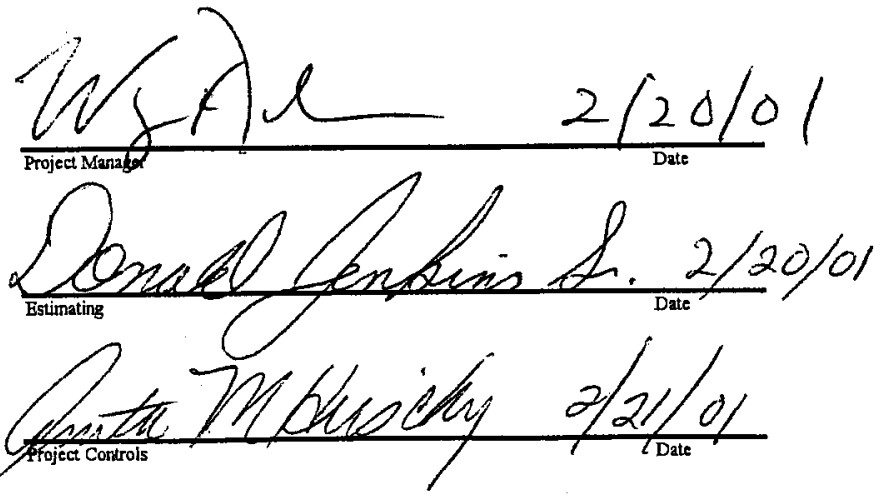




\section{Appendix C}

\section{Evaluation of Risk}


CAU 490 CADD

Appendix C

Revision: 0

Date: $02 / 28 / 2001$

Page C-1 of C-1

A detailed assessment of risk was not performed for this CAU because COCs exceeding PALs will not be left in place. 


\section{Appendix D}

Response to NDEP Comments 


\section{NEVADA ENVIRONMENTAL RESTORATION PROJECT} DOCUMENT REVIEW SHEET

\begin{tabular}{|c|c|c|c|c|c|}
\hline \multicolumn{4}{|c|}{ 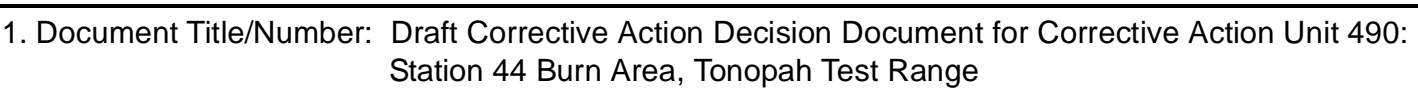 } & \multicolumn{2}{|c|}{ 2. Document Date: September 2000} \\
\hline \multicolumn{4}{|c|}{ 3. Revision Number: 0} & \multicolumn{2}{|c|}{ 4. Originator/Organization: IT Corporation } \\
\hline \multicolumn{6}{|c|}{ 7. Review Criteria: Full } \\
\hline \multicolumn{4}{|c|}{ 8. Reviewer/Organization/Phone No.: Ken Scarbrough, NDEP, (775) 687-4670 } & \multicolumn{2}{|l|}{ 9. Reviewer's Signature: } \\
\hline $\begin{array}{l}\text { 1) Overall } \\
\text { Document }\end{array}$ & & $\begin{array}{l}\text { Throughout the document, the use of singular } \\
\text { verses plural is incorrect indicating that the } \\
\text { document was "boiler plated" from a CAU that } \\
\text { only had one site. Review document and } \\
\text { correct. }\end{array}$ & \multicolumn{2}{|c|}{$\begin{array}{l}\text { The document was reviewed by technical editors for the incorrect } \\
\text { use of singular versus plural. It is assumed that this comment } \\
\text { refers to the word "site" being used in the document to describe } \\
\text { individual CASs and the entire CAU. The text has been modified to } \\
\text { clarify the use of the term "site." }\end{array}$} & In part \\
\hline $\begin{array}{l}\text { 3) Page A-1 } \\
\text { of A-63 }\end{array}$ & & $\begin{array}{l}\text { The first page of the report has been "boiler } \\
\text { plated" from an appendix document and has } \\
\text { several related errors. Section A.1.1. title } \\
\text { does not match the Table of Contents. }\end{array}$ & \multicolumn{2}{|c|}{$\begin{array}{l}\text { The error made in replacing the first page of the document with the } \\
\text { first page of Appendix A has been corrected. }\end{array}$} & Yes \\
\hline
\end{tabular}




\section{NEVADA ENVIRONMENTAL RESTORATION PROJECT}

\section{DOCUMENT REVIEW SHEET}

\begin{tabular}{|c|c|c|c|c|}
\hline $\begin{array}{l}\text { 10. Comment } \\
\text { Number/ } \\
\text { Location }\end{array}$ & 11. Type & 12. Comment & 13. Comment Response & 14. Accept \\
\hline $\begin{array}{l}\text { 4) Page } 8 \text { of } \\
25 \\
\text { FTA Last } \\
\text { Bullet }\end{array}$ & & $\begin{array}{l}\text { Statement indicates that } 5 \text { samples had } \\
\text { elevated concentrations of TPH, but it does } \\
\text { not indicate how many samples were } \\
\text { collected. }\end{array}$ & $\begin{array}{l}\text { Statement changed as follows: } \\
\text { "Total petroleum hydrocarbons exceeded the NDEP action level of } \\
100 \mathrm{mg} / \mathrm{kg} \text { for TPH-diesel in } 5 \text { of the } 18 \text { soil samples collected. The } \\
5 \text { samples that exceeded the action level were collected from two of } \\
\text { the five locations within the excavations." }\end{array}$ & Yes \\
\hline $\begin{array}{l}\text { 7) Page } 17 \text { of } \\
25 \\
\text { Section } 3.3\end{array}$ & & $\begin{array}{l}\text { It states that the hydrocarbons from FTA } \\
\text { extended into the existing CAU } 424 \text { Use } \\
\text { Restriction Area will not be removed. How will } \\
\text { CAU } 424 \text { files and future workers know that } \\
\text { hydrocarbons from CAU } 490 \text { have impacted } \\
\text { CAU } 424 \text { ? }\end{array}$ & $\begin{array}{l}\text { Section 3.3.3.1 regarding the removal of TPH impacted soil in the } \\
\text { CAU } 424 \text { Use Restriction Area has been added and reads, } \\
\text { "CAU } 424 \text { Use Restriction Area } \\
\text { A limited amount of TPH-impacted soil extends into the CAU } 424 \\
\text { Use Restriction Area Landfill A3-8, CAS 03-08-002-A308. As part } \\
\text { of the Clean Closure by Excavation and Disposal alternative for } \\
\text { FTA, the Use Restriction Area will not be accessed. If } \\
\text { TPH-impacted soils are found at the boundary of the closed CAU } \\
424 \text { Use Restriction Area, a Record of Technical Change for the } \\
\text { CAU } 424 \text { Closure Report will be required." }\end{array}$ & Yes \\
\hline
\end{tabular}


NEVADA ENVIRONMENTAL RESTORATION PROJECT

DOCUMENT REVIEW SHEET

\begin{tabular}{|c|c|c|c|c|}
\hline $\begin{array}{l}\text { 10. Comment } \\
\text { Number/ } \\
\text { Location }\end{array}$ & 11. Type* & 12. Comment & 13. Comment Response & 14. Accept \\
\hline $\begin{array}{l}\text { 8) Page A-11 } \\
\text { of A-63 } \\
1^{\text {st }} \text { Paragraph }\end{array}$ & & $\begin{array}{l}\text { The } 5^{\text {th }} \text { sentence is not understandable. } \\
\text { Review complete paragraph and re-write. }\end{array}$ & $\begin{array}{l}\text { Paragraph reviewed and rewritten as follows: } \\
\text { "Fifty-five environmental soil samples were collected and submitted } \\
\text { for laboratory analyses from } 26 \text { separate locations using } \\
\text { direct-push sampling. As prescribed in the CAIP, the sampling } \\
\text { locations were both biased and random. The samples were } \\
\text { collected from } 0 \text { to } 1 \mathrm{ft} \text { and } 3 \text { to } 4 \mathrm{ft} \text { bgs. Refer to Figure A.2-3 for } \\
\text { sample locations. Aerial photographs revealed discrepancies } \\
\text { between site markers and historical site boundaries. Several } \\
\text { random sampling locations were originally sited over the landfill cell } \\
\text { A3-2 Use Restriction Area from CAU } 424 \text {, located immediately to } \\
\text { the west of SSY. As a result, the } 15 \text { random sample locations were } \\
\text { regenerated and moved east, away from landfill cell A3-2. The } \\
\text { eight biased sample locations were based on surface staining and } \\
\text { aerial photographs indicating areas of possible contamination } \\
\text { accumulation. None of the eight biased sample locations had to be } \\
\text { moved." }\end{array}$ & Yes \\
\hline $\begin{array}{l}\text { 10) Table } \\
\text { A.3-5 }\end{array}$ & & $\begin{array}{l}\text { The site identified in the Table's site do not } \\
\text { match the samples identified on each page. } \\
\text { The abbreviation "NI" is not defined in the } \\
\text { report. }\end{array}$ & $\begin{array}{l}\text { Table changed to include subheadings to match the samples } \\
\text { identified on each page. The abbreviation NI (Not Indicated), has } \\
\text { been added to the table footnotes. }\end{array}$ & Yes \\
\hline
\end{tabular}


NEVADA ENVIRONMENTAL RESTORATION PROJECT

DOCUMENT REVIEW SHEET

\begin{tabular}{|c|c|c|c|c|}
\hline $\begin{array}{l}\text { 10. Comment } \\
\text { Number/ } \\
\text { Location }\end{array}$ & 11. Type* & 12. Comment & 13. Comment Response & 14. Accept \\
\hline $\begin{array}{c}\text { 11) General } \\
\text { Figures }\end{array}$ & & $\begin{array}{l}\text { The figures do not delineate the limits of the } \\
\text { hydrocarbons/area to be excavated identified } \\
\text { as FTA and SSY sites. The reader is forced } \\
\text { to interpret the data and make his/her own } \\
\text { determination of the limits of environmental } \\
\text { impacts at the site. Appendix B - Costs } \\
\text { Estimate is the only place the reader is } \\
\text { provided information on the size/extent of the } \\
\text { environmental impact th the site. }\end{array}$ & $\begin{array}{l}\text { Shading has been added to Figures A.2-1-and A.2-3 to show the } \\
\text { contaminated areas. } \\
\text { Section 3.3.3 was changed to include estimated volumes (see } \\
\text { Comment 2). }\end{array}$ & Yes \\
\hline
\end{tabular}

a Comment Types: $M$ = Mandatory, $S=$ Suggested.

Return Document Review Sheets to DOE/NV Environmental Restoration Division, Attn: QAC, M/S 505. 


\section{Distribution}

* Provide a copy in distribution of Rev. 0 and subsequent revisions if applicable.

Copies of only the NDEP-approved document will be distributed to others.

\section{$\underline{\text { Copies }}$}

Paul J. Liebendorfer

2 (Controlled)*

State of Nevada

Bureau of Federal Facilities

Division of Environmental Protection

333 W. Nye Lane, Room 138

Carson City, NV 89706-0851

Michael McKinnon

1 (Controlled)*

State of Nevada

Bureau of Federal Facilities

Division of Environmental Protection

555 E. Washington, Suite 4300

Las Vegas, NV 89101

Sabrina Lawrence

1 (Controlled)*

Environmental Restoration Division

DOE/Nevada Operations Office

P.O. Box 98518, M/S 505

Las Vegas, NV 89193-8518

Janet Appenzeller-Wing

1 (Uncontrolled)*

Environmental Restoration Division

DOE/Nevada Operations Office

P.O. Box 98518, M/S 505

Las Vegas, NV 89193-8518

Kevin Cabble

1 (Uncontrolled)*

Environmental Restoration Division

DOE/Nevada Operations Office

P.O. Box 98518, M/S 505

Las Vegas, NV 89193-8518 


\section{Copies}

Dennis Gustafson

1 (Uncontrolled)*

Bechtel Nevada

P.O. Box 98521, M/S NTS306

Las Vegas, NV 89193-8521

Wayne Johnson

1 (Uncontrolled)*

Bechtel Nevada

P.O. Box 98521, M/S NTS306

Las Vegas, NV 89193-8521

Dustin Wilson

1 (Uncontrolled)*

ITLV

P.O. Box 93838

Las Vegas, NV 89193

IT Corporation Central Files

1 (Uncontrolled)*

ITLV

P.O. Box 93838

Las Vegas, NV 8919

Jeffrey Johnson

1 (Uncontrolled)*

ITLV

P.O. Box 93838

Las Vegas, NV 89193

Robert McCall

1 (Uncontrolled)*

ITLV

P.O. Box 93838

Las Vegas, NV 89193

U.S. Air Force

DOE Liaison Officer

P.O. Box 98518, M/S 505

Las Vegas, NV 89193-8518

Eloisa V. Hopper

3 (Controlled)*

U.S. Air Force

$99 \mathrm{ABW} / \mathrm{EM}$

4349 Duffer Dr., Suite 1601

Nellis AFB, NV 89191-7007

1 (Uncontrolled)* 


\section{Copies}

U.S. Air Force

1 (Controlled)*

AWFC RMO/RML

3770 Duffer Dr.

Nellis AFB, NV 89191-7007

U.S. Department of Energy

1 (Uncontrolled, electronic copy)

Office of Scientific and Technical Information

P.O. Box 62

Oak Ridge, TN 37381

Manager, Southern Nevada FFACO

1 (Controlled)

Public Reading Facility

1 (Uncontrolled)

P.O. Box 98521, M/S NLV040

Las Vegas, NV 89193-8521

Manager, Northern Nevada FFACO

1 (Uncontrolled)

Public Reading Room

c/o Nevada State Library \& Archives

100 North Stewart Street

Carson City, NV 89701-4285

Technical Information Resource Center

1 (Uncontrolled)

DOE/Nevada Operations Office

P.O. Box 98518, M/S 505

Las Vegas, NV 89193-85181

FFACO Support Office

1 (Controlled)

IT Corporation

P.O. Box 93838

Las Vegas, NV 89193

Alex MacKinlay

1 (Uncontrolled)*

IT Corporation

P.O. Box 93838

Las Vegas, NV 89193 